\title{
Nanocrystalline Pyrite for Photovoltaic Applications
}

DOI:

10.1002/slct.201800405

\section{Document Version}

Accepted author manuscript

Link to publication record in Manchester Research Explorer

\section{Citation for published version (APA):}

Khalid, S., Ahmed, E., Riaz, K. N., \& Malik, M. (2018). Nanocrystalline Pyrite for Photovoltaic Applications.

ChemistrySelect. https://doi.org/10.1002/slct.201800405

\section{Published in:}

ChemistrySelect

\section{Citing this paper}

Please note that where the full-text provided on Manchester Research Explorer is the Author Accepted Manuscript or Proof version this may differ from the final Published version. If citing, it is advised that you check and use the publisher's definitive version.

\section{General rights}

Copyright and moral rights for the publications made accessible in the Research Explorer are retained by the authors and/or other copyright owners and it is a condition of accessing publications that users recognise and abide by the legal requirements associated with these rights.

\section{Takedown policy}

If you believe that this document breaches copyright please refer to the University of Manchester's Takedown Procedures [http://man.ac.uk/04Y6Bo] or contact uml.scholarlycommunications@manchester.ac.uk providing relevant details, so we can investigate your claim.

\section{OPEN ACCESS}


DOI: 10.1002/ ((please add manuscript number))

Article type: ((Review))

\section{Nanocrystalline Pyrite for Photovoltaic Applications}

Sadia Khalid, Ejaz Ahmed, Yaqoob Khan, Khalid Nadeem Riaz, and Mohammad Azad Malik*

(Dedicated to Dr. Syed Tajammul Hussain (Late))

Dr. Sadia Khalid 1,

Department of Physics, Bahauddin Zakariya University, Multan 60800, Pakistan

Nanoscience \& Technology Department, National Centre for Physics, Shahdra Valley Road

Quaid-i-Azam University Campus, Islamabad 45320, Pakistan.

Prof. Dr. Ejaz Ahmed 2

Department of Physics, Bahauddin Zakariya University, Multan 60800, Pakistan

Dr. Yaqoob Khan

Nanoscience \& Technology Department, National Centre for Physics, Shahdra Valley Road Quaid-i-Azam University Campus, Islamabad 45320, Pakistan.

Dr. Khalid Nadeem Riaz

Department of Physics, Faculty of Sciences, University of Gujrat, Hafiz Hayat Campus, Gujrat 50700, Pakistan.

Dr. Mohammed Azad Malik

School of Materials, The University of Manchester, Oxford Road, Manchester, M13 9PL, U.K.

Email: azad.malik@manchester.ac.uk.

\section{Abstract}

Transition metal sulfides (TMSs) are of special interest in energy conversion and storage devices. Amongst all sulfides, fool's gold or iron pyrite $\left(\mathrm{FeS}_{2}\right)$ is potentially an attractive candidate for photovoltaic applications. Iron pyrite has risen to prominence due to its distinct properties and abundance in nature to meet the large scale needs. It is considered as environmentally benign solar absorber material with high absorption coefficient, $\alpha>6 \times 10^{5} \mathrm{~cm}^{-1}$ for $\lambda \geq 700 \mathrm{~nm}$ and suitable energy bandgap $\left(E_{\mathrm{g}}=0.95\right.$ eV). Numerous physical and chemical methods have been employed to deposit nanocrystalline pyrite thin films directly from source materials or indirectly by 


\section{WILEY-VCH}

sulfuration. This review gives an overview of pyrite as a low cost photovoltaic absorber material for contemporary solar cell structures. In addition, practical approaches like the rational design of nanocomposites, band gap engineering and nanostructure synthesis of pyrite for improving its properties particularly photovoltaic properties are also deliberated. Moreover, limitations, challenges, remedies and prospects of pyrite as potential photovoltaic material are also reviewed to further advance the development of pyrite-based solar cell configurations.

\section{Table of Contents}

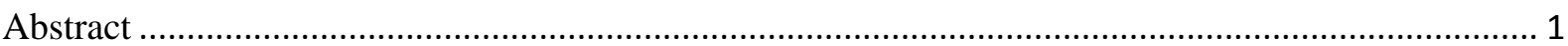

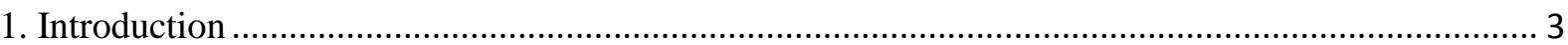

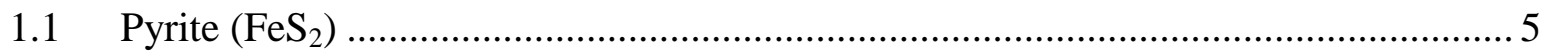

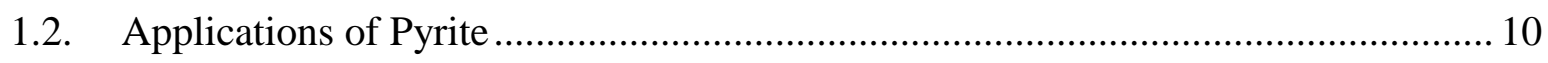

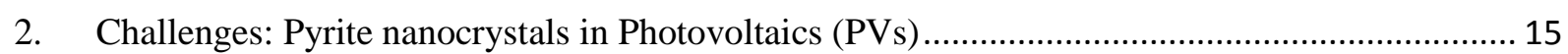

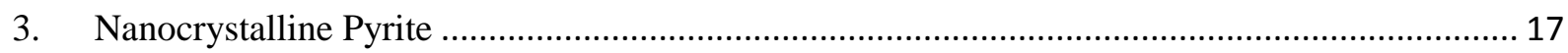

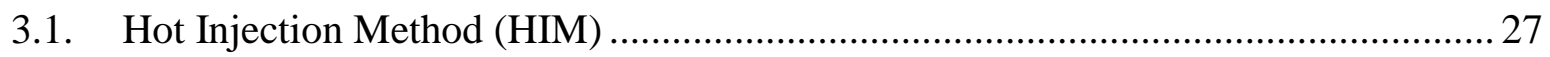

3.2. Hydrothermal (HTM) or Solvothermal Method (STM) ....................................... 29

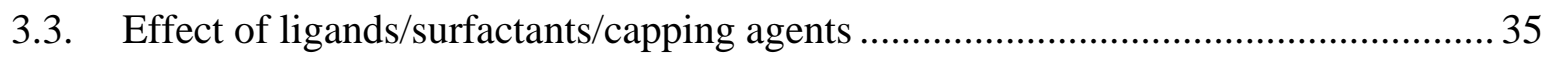

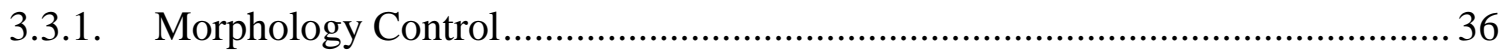

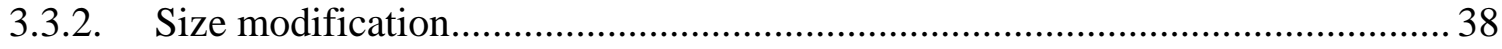

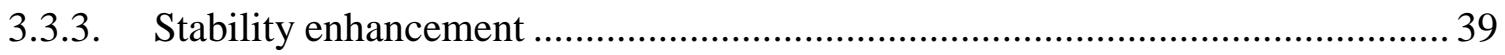

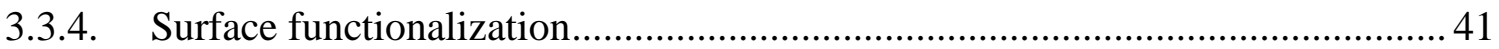

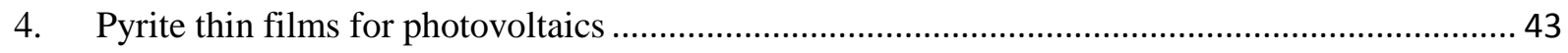

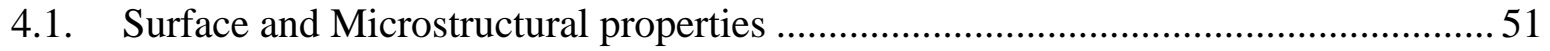

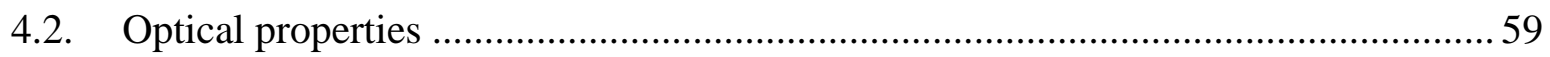

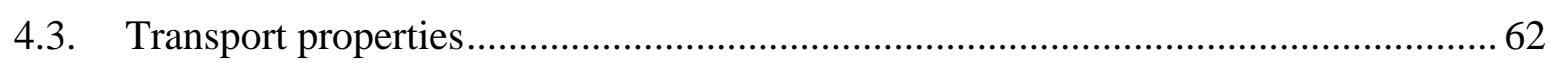

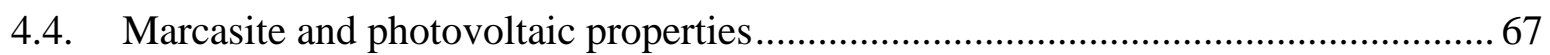

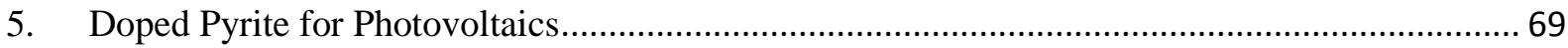

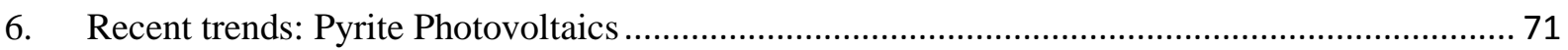

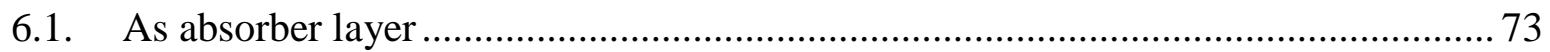




\section{WILEY-VCH}

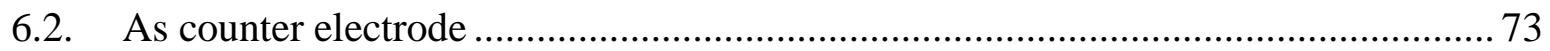

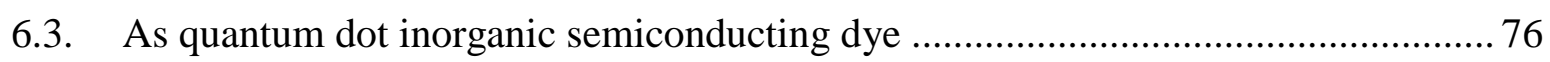

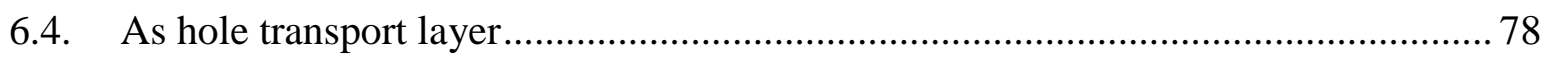

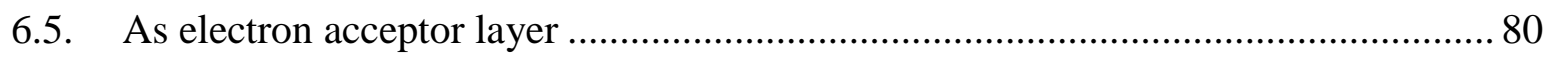

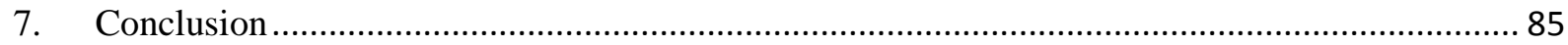

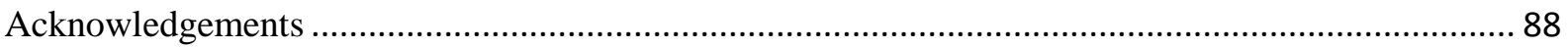

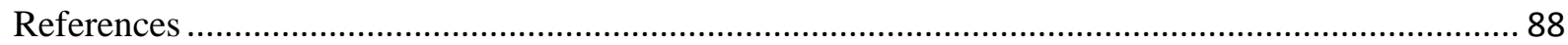

\section{Introduction}

The estimated energy consumption in 2011 for a world population of nearly 7 billion was 15 TW (tera watt). ${ }^{[1]}$ The world energy demand will be $20 \mathrm{TW}$ green energy to stabilize $\mathrm{CO}_{2}$ in atmosphere in year 2050. ${ }^{[2]}$ The problem of carbon emission means that it has become necessary to explore every technology that may assist to achieve the production of energy in a sustainable way. Solar energy is the most reliable and sustainable renewable energy source that can fulfil the world energy demands. Solar energy striking the earth in one hour $(4.3 \times$ $\left.10^{20} \mathrm{~J}\right)$ is more than the total energy consumed $\left(4.1 \times 10^{20} \mathrm{~J}\right)$ by humans in a whole year. This is twice the amount of energy that will ever be obtained from all non-renewable resources. Solar energy can be harvested in different forms; sunlight to thermal energy (solar-thermal conversion), electrical energy (photovoltaics) and chemical energy (photo-chemical). Solar cells have been identified as one of the most promising, clean and scalable devices for solar to electrical energy conversion. However, solar cells still provide less than $0.1 \%$ of the world electricity as they are expensive when compared to electricity generated through fossil combustion. Photovoltaics may, therefore, potentially ensure the transition towards a sustainable energy supply system for the 21 st century. It is promising as it can provide environmentally benign energy with no emissions and has the potential to enhance energy security because of its global availability. 


\section{WILEY-VCH}

Among the compound semiconductor materials, metal chalcogenides have been extensively studied and widely used for linear and nonlinear optical devices and solar cells. Photovoltaic market is still dominated by conventional silicon solar cells in spite of their high cost. $^{[3,4]}$ Copper indium gallium diselenide (CIGS) solar cells, organic and hybrid solar cells (Bulk Heterojunction), dye sensitized solar cell (DSSCs), quantum dot solar cells (QSC) are emerging generations of modern photovoltaics. ${ }^{[5]}$ But the main issues related to these growing generations are the stability, low efficiency and life time of the devices. ${ }^{[6]}$ Organometal halide perovskites $\left(\mathrm{CH}_{3} \mathrm{NH}_{3} \mathrm{PbX}_{3}\right)$ solar cells have recently emerged as a promising photovoltaic technology ${ }^{[7]}$ Nevertheless the instability of perovskite in terms of humidity and degradation is the key concern for sustainable photovoltaics. ${ }^{[8]}$ A significant factor for economically sustainable photovoltaics is also the production of low cost green energy solar materials with effective optical absorption. ${ }^{[9,10]}$ One of the limitations associated with these materials is their availability in earth's crust. ${ }^{[1]}$ Most of conventional photovoltaic inorganic semiconductors are not economically sustainable. ${ }^{[12]}$ Wadia et al. ${ }^{[13]}$ investigated 23 promising low cost unconventional semiconducting solar materials and identified pyrite $\left(\mathrm{FeS}_{2}\right)$ as the most promising solar absorber on the basis of cost and availability. Thin film fabrication of nanocrystalline materials for large-scale photovoltaics and other optoelectronic applications is an emerging area in materials science. Nanocrystalline thin films are economically and technically foremost trend of present day photovoltaic technologies. Nanoscale plasmonic energy conversion has been anticipated as a promising alternative to conventional electronhole separation in semiconductor devices. Nanostructured films are highly efficient for charge transfer in nanocrystalline solar cells. ${ }^{[14,15]}$ Efficiency of pyrite based solar cells can be enhanced by pyrite nanocrystals thus extending light energy harvesting. A general comparison of some semiconducting photovoltaic materials is given in Table 1: 
Table 1. Device efficiency and bandgap of some photovoltaic materials. ${ }^{[16,17]}$

\begin{tabular}{lcc}
\hline Materials & Bandgap (eV) & Efficiency (\%) \\
\hline Si (crystalline) & 1.2 & $22.9 \pm 0.6$ \\
GaAs (thin film) & 1.43 & $24.1 \pm 1.0$ \\
CdTe (thin film) & 1.44 & $17.5 \pm 0.7$ \\
CIGS (thin film) & 1.1 & $15.7 \pm 0.5$ \\
CZTS & $1.4-1.6$ & $11.1 \pm 0.3$ \\
FeS & 0.95 & $\sim 3$ \\
\hline
\end{tabular}

The original research on the photovoltaic potential of iron pyrite started in wake of oil crisis in 1980 s. ${ }^{[17,18]}$ Subsequent studies proved it to be an important photovoltaic material due to its distinct properties and abundance in nature to meet the large scale needs. It is considered as environmentally benign solar absorber material with high absorption in the visible light and suitable energy band gap $(0.95 \mathrm{eV}) .{ }^{[12,13,19,20]} \mathrm{A}$ most recent review by Shukla et al. ${ }^{[21]}$ highlights some important issues related to its use for photovoltaic application, however their review lacks the comprehensive investigation in this field. Herein we present a comprehensive coverage of pyrite including the synthetic routes for pyrite nanocrystalline inks, methods for thin films depositions, type and effects of precursors used, applications and issues related to its applications particularly photovoltaic and the possible remedies to address those issues.

\subsection{Pyrite $\left(\mathrm{FeS}_{2}\right)$}

Iron disulfide $\left(\mathrm{FeS}_{2}\right)$ has two polymorphs e.g., pyrite and marcasite. Pyrite is the most abundant of transition metal disulfides having formula $\mathrm{MS}_{2}(\mathrm{M}=\mathrm{Mn}, \mathrm{Fe}, \mathrm{Co}, \mathrm{Ni}, \mathrm{Cu}$ or $\mathrm{Zn})$. These metal disulfides have several applications e.g., photovoltaics, optoelectronics, oxygen reduction reaction (ORR) catalysts and high temperature superconductors. ${ }^{[22]}$ Pyrite exhibits 


\section{WILEY-VCH}

NaCl-type crystal structure (cubic space group Pa $\overline{3}\left(T_{h}^{6}\right)$, Pearson Symbol: cP12, Strukturbericht Designation: C2, no. 205, $\mathrm{Z}=4$ ), low-spin $\mathrm{Fe}^{\mathrm{II}}$ atoms $\left(\mathrm{d}_{6}, \mathrm{t}_{2} \mathrm{~g}^{6}\right)$ are octahedrally coordinated at corners and face centres of the cubic unit cell while the disulfide dumb-bells (dimers) atoms $\mathrm{S}_{2}{ }^{2-}$ lie at the centre of the cube and the mid points of the cubic unit cell. The $\mathrm{S}_{2}$ group occupies the $\mathrm{Cl}$ positions of $\mathrm{NaCl}$ structure while the Fe atoms occupy the Na positions (Figure 1). The axis of the $\mathrm{S}_{2}{ }^{2-}$ dimers is oriented along $\langle 111\rangle$ directions parallel to four intersecting diagonals of the cubic space lattice thus giving pyrite hemihedral symmetry. Each $\mathrm{S}$ atom is coordinated to three Fe and one $\mathrm{S}$ atom in a distorted tetrahedral configuration. In the unit cell, the four iron atoms are located at positions $(0,0,0),(0,1 / 2$, $1 / 2),(1 / 20,1 / 2)$, and $(1 / 2,1 / 2,0)$. The eight sulfur atoms are in position $\pm(u, u, u), \pm(u+1 / 2$, $1 / 2-\mathrm{u},-\mathrm{u}), \pm(-\mathrm{u}, \mathrm{u}+1 / 2,1 / 2-\mathrm{u})$, and $\pm(1 / 2-\mathrm{u},-\mathrm{u}, \mathrm{u}+1 / 2)$ where the Wyckoff parameter $\mathrm{u}=0.386$. The lattice parameter $a=0.54175 \mathrm{~nm}$, distance between two iron atoms on the 110 face is $0.382 \mathrm{~nm}$, distance between two sulfur atoms of the sulfur pair on the 111 axis is $0.206 \mathrm{~nm}$, distance between iron and the centre of a sulfur pair on the 001 face is $0.270 \mathrm{~nm}$ and the distance between adjacent sulfur atoms is $0.226 \mathrm{~nm}$. S-Fe-S bond angle is 85.66 to $94.34^{\circ}, \mathrm{Fe}-$ $\mathrm{S}-\mathrm{Fe}$ bond angle is $115.5^{\circ}$ and $\mathrm{S}-\mathrm{S}-\mathrm{Fe}$ bond angle is $102.4^{\circ} .^{[23-26]}$

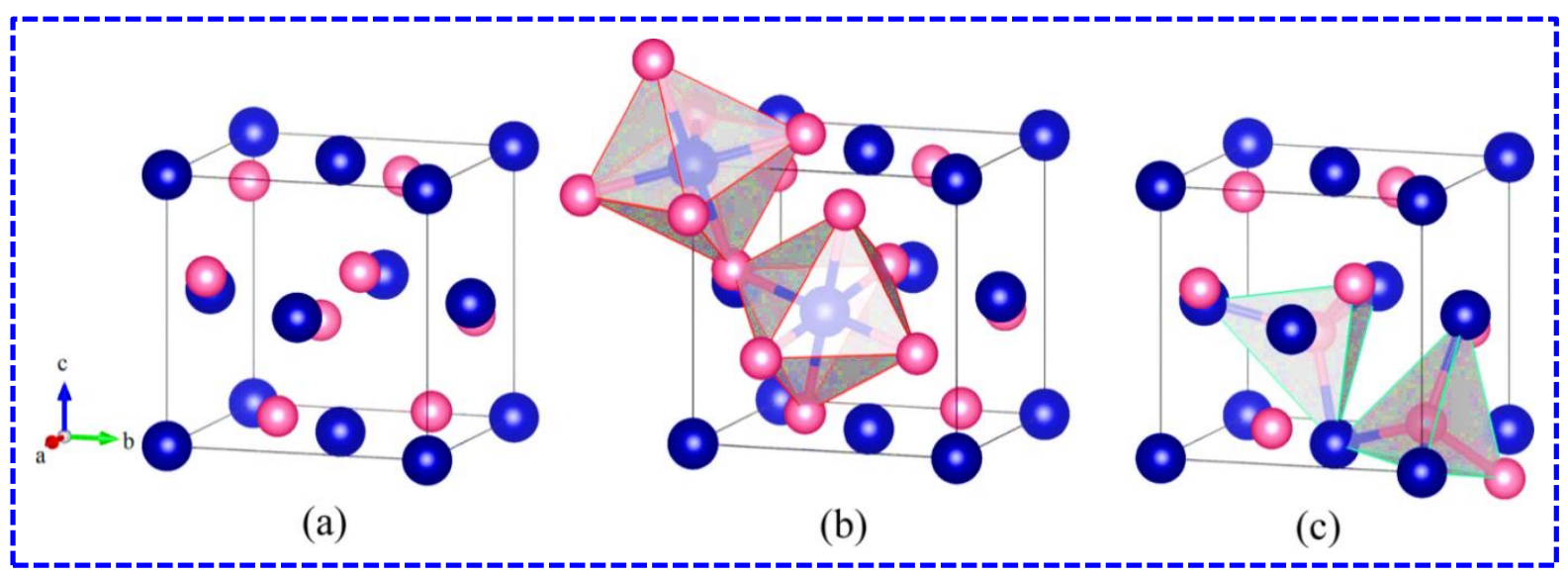

Figure 1. (a) Conventional unit cell of pure pyrite $\mathrm{FeS}_{2}$. Blue and pink balls represent the Fe and $\mathrm{S}$ atoms, respectively. (b) Octahedron comprised of $\mathrm{S}_{2}{ }^{2-}$ anions. (c) Tetrahedron comprised of three $\mathrm{Fe}^{2+}$ cations and one $\mathrm{S}_{2}{ }^{2-}$ anion. ${ }^{[27]}$ Reproduced with permission from ref. [27]. Copyright 2017 American Chemical Society. 


\section{WILEY-VCH}

Pyrite is diamagnetic in nature with $\mathrm{Fe}$ ions adopting $2+$ valence state. $\mathrm{Fe}^{2+}$ stays in a low spin state in pyrite indicating the strength of the ligand field due to $\mathrm{S}_{2}{ }^{2-}$ anions. For ideal stoichiometric $\mathrm{FeS}_{2}$ ligand-field and molecular orbital theory predict $\mathrm{Fe}$ eg and $\mathrm{S}$ sp3 states to form bonding and antibonding orbitals. ${ }^{[28,29]}$ The $3 \mathrm{~d}$ orbitals of Fe are split into sub-bands $\mathrm{t}_{2 \mathrm{~g}}$ (occupied with six paired $\mathrm{d}$ - electrons) and $\mathrm{e}_{\mathrm{g}}$ (unoccupied) in the approximately $O_{h}$ (octahedral) local symmetry, while the $3 p$ orbitals of $\mathrm{S}$ are split into four groups in the $C_{3 v}$ (tetrahedral) symmetry. In contrast, $\mathrm{Fe}$ eg and $\mathrm{S} p p \sigma^{*}$ orbitals strongly hybridize in the conduction bands. Conduction band minimum (CBM) of pyrite is almost purely $\mathrm{S} p p \sigma^{*}$. Top of the valence band comprises of non-bonding $\mathrm{Fe} 3 \mathrm{~d} \mathrm{t}_{2 \mathrm{~g}}$ states that lie above a bonding $\mathrm{S} 3 \mathrm{p}$ Fe $3 \mathrm{~d}$ e band (Figure 2). ${ }^{[29-32]}$

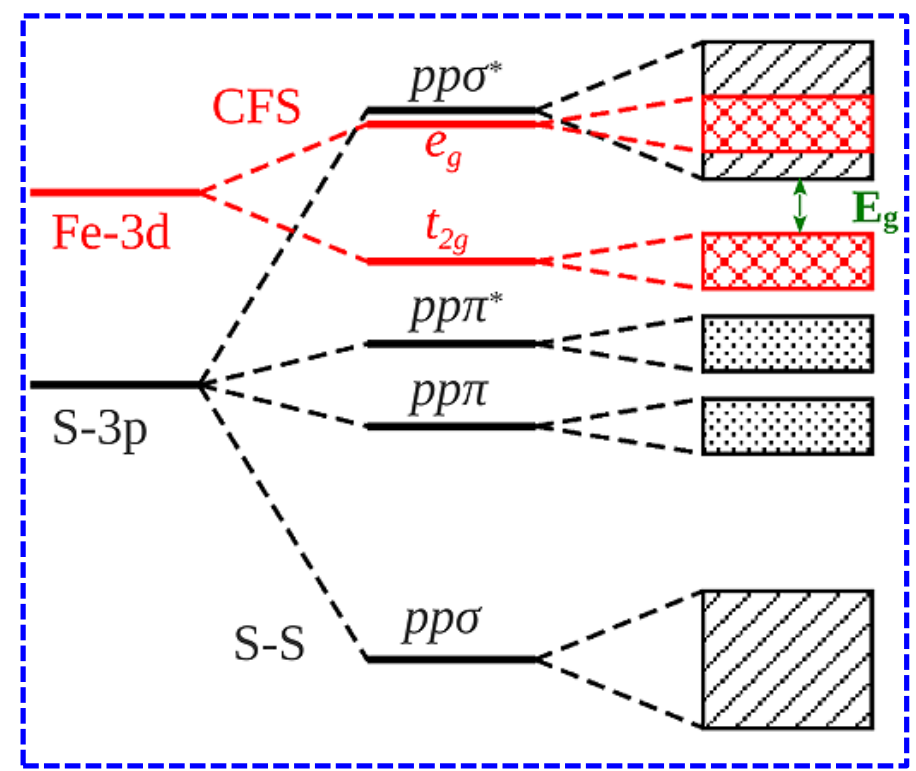

Figure 2. Sketch of the energy diagram for the Fe 3d and S 3p orbitals of bulk pyrite under the influences of crystal-field splitting (CFS) and $\mathrm{S}-\mathrm{S}$ dimerization. The green arrow denotes the band gap $\left(\mathrm{E}_{\mathrm{g}}\right) .{ }^{[32]}$ Reproduced with permission from ref. ${ }^{[32]}$. Copyright 2012 American Chemical Society. 


\section{WILEY-VCH}

Semiconducting properties of pyrite arise due to existing free charge carriers in the crystal structure. Free charge carriers generate due to ${ }^{[33]}$

- deviation from stoichiometric composition

- impurity elements in solid solution

- thermal excitation across the energy gap

Conductivity of natural pyrite ranges between 0.02 and $562.32(\Omega \mathrm{cm})^{-1}{ }^{[34]}$ Usually, $p$-type conductivity arises in pyrite with $\mathrm{S} / \mathrm{Fe}$ ratio $>2$, while $n$-type of conductivity occurs due to sulfur deficiency. Defects in structure are always there as the defect formation requires only a small amount of energy. ${ }^{[29]}$ A donor defect is created by sulfur deficiency and an acceptor defect is created by sulfur excess. ${ }^{[35]}$ Sun et al. reported that intrinsic p-type conductivity of pyrite is induced by oxygen ${ }^{[36]}$ Ennaoui et al. reported a bandgap of about $0.9 \mathrm{eV}$ for natural crystals of pyrite, $0.95 \mathrm{eV}$ with high absorption coefficient absorption $\left(\alpha>10^{5} \mathrm{~cm}^{-1}\right)$ for synthetic polycrystalline and single crystal. The diffusion length of minority carriers varies from 100 to $1000 \mathrm{~nm}$ and higher carrier mobility was observed $200-300 \mathrm{~cm}^{2} / \mathrm{V}$ even for thin films. ${ }^{[37]}$ Theoretical efficiency of pyrite is $\sim 31 \%$ slightly less than Shockley-Queisser limit $33.7 \%$ for a material with a bandgap of $1.34 \mathrm{eV}$. On the other hand, $20 \mathrm{~nm}$ of it can absorb as much light as $300 \mu \mathrm{m}$ of silicon due to its excellent absorption coefficient (penetration depth: $\delta=\sim 15 \mathrm{~nm}$ in the visible) ${ }^{[38]}$ so less raw material is required for thin film solar cells. The impure pyrite and presence of defects are considered as main reasons for its ineffective photovoltaic performance. Comprehensive and intensive work is required to understand the pyrite photovoltaics. In this review, we will try to cover all aspects related to pyrite from basics to the implications of various structural and impurity factors on its photovoltaic performance.

Thermal kinetics for various phases of iron-sulfur (Fe-S) binary system have been extisively studied in literature. ${ }^{[39-43]}$ The only stable binary phases in Fe-S system at $>200{ }^{\circ} \mathrm{C}$ 


\section{WILEY-VCH}

or near ambient temperature are pyrrhotite and pyrite. The most S-rich phase is pyrite and equilibrium bulk phase diagrams represent it as a line-compound. The homogeneity range of pyrite is limited by two parallel lines, one at the stoichiometric composition, the second at a distance of $0.5 \mathrm{~mol} \%$ shifted to the Fe-rich side. So, it is certainly possible to form nonstoichiometric S-deficient impurity phases. Under equilibrium conditions pyrite decomposes to $\mathrm{Fe}_{1-\mathrm{x}} \mathrm{S}$ (pyrrhotite) and sulfur at the peritectic point at $742.85{ }^{\circ} \mathrm{C}(1016 \mathrm{~K})$ (). The decomposition of pyrite can be expressed as:

$$
\mathrm{FeS}_{2}(s) \rightarrow \mathrm{FeS}_{1-x}+1-x S_{2}(g)
$$

As pyrite decomposes without melting, so no melt growth technique can be used for synthesis of pyrite. Peritectic decomposition temperature could be increased up to $806.85{ }^{\circ} \mathrm{C}(1080 \mathrm{~K})$ by increasing sulfur pressure up to 5 kbar but no melting could be achieved. Every synthetic method involves specific thermodynamic data elaborated by Ennaoui et al. ${ }^{[17]}$ Phase diagram of Fe-S system is shown in Figure 3. 


\section{WILEY-VCH}

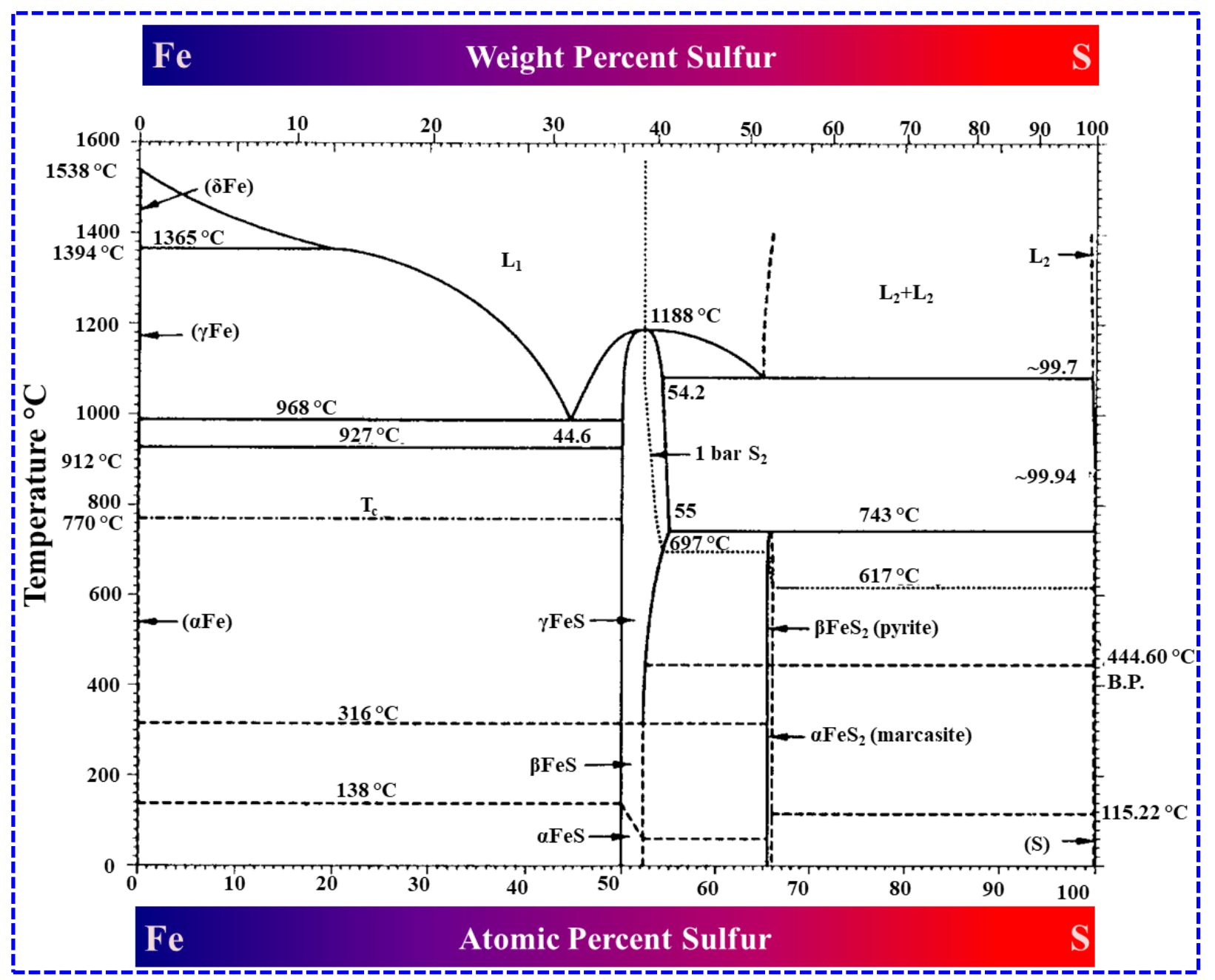

Figure 3. Phase relations in the system Fe-S. ${ }^{[17]}$ Reproduced with permission from ref. ${ }^{[17]}$. Copyright 1993 Elsevier Ltd. (Ref. T.B. Massalski, Binary Alloy Diagrams, Vol. 1 (Am. Soc. Metals Park, Ohio, 1986) pp. 1762, 1765.)

\subsection{Applications of Pyrite}

Pyrite has wide area of applications (Figure 4) such as energy storage and conversion field: photovoltaics, ${ }^{[4,45]}$ photocatalytic hydrogen production, ${ }^{[46-49]}$ batteries, ${ }^{[50-61]}$ supercapacitors, ${ }^{[62]}$ photocapacitors, ${ }^{[63]}$ thermoelectricity ${ }^{[64,65]}$ electronics, ${ }^{[66,67]}$ optoelectronics, ${ }^{[68]}$ spintronics $;^{[69]}$ environmental applications $;{ }^{[70-74]}$ hydrogenation; ${ }^{[75]}$ sensors $;{ }^{[76]}$ agriculture ${ }^{[77,78]}$ and emerging biomedical field. ${ }^{[79-81]}$ 


\section{WILEY-VCH}

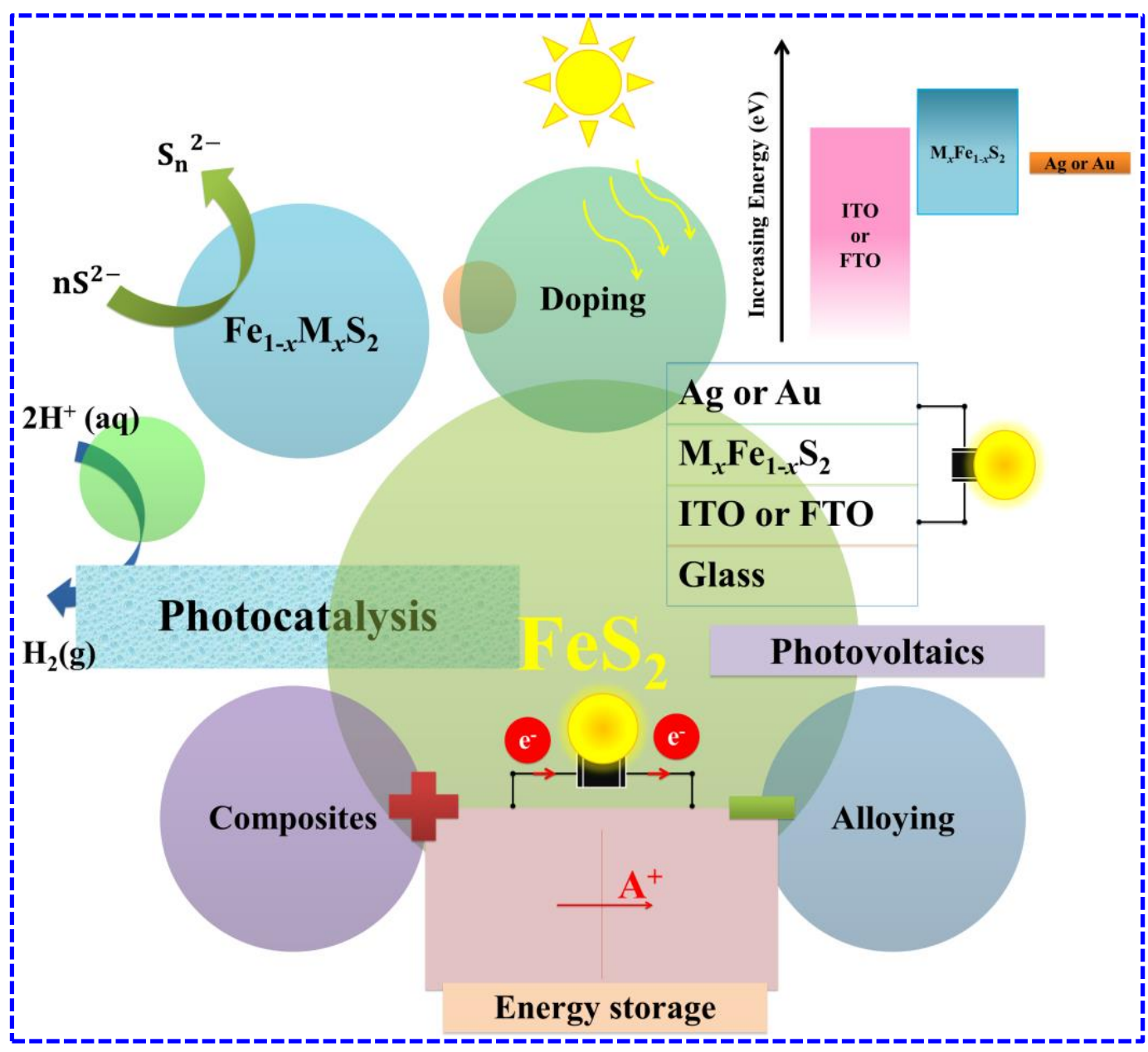

Figure 4. Applications of pyrite $\left(\mathrm{FeS}_{2}\right)$

Recent research trends exemplifies synthesis of pyrite hybrid structures to combine and enhance properties of compounds specially for photovoltaics, optoelectronics, magnetoelectronic devices, environmental, biomedical and charge storage applications for numerous applications such as :

- Photovoltaics: mesoporous silica (MS)@CuO@ $\mathrm{FeS}_{2},{ }^{[82]}$ P3HT:PCBM:FeS $2,{ }^{[83]} \mathrm{FeS}_{2}$ /graphene, ${ }^{[84]} \mathrm{FeS}_{2}$ nanotube arrays on $\mathrm{ZnO}$ nanotube arrays ${ }^{[85]}$

- Optoelectronics : $\mathrm{FeS}_{2} \mathrm{NCs} /$ graphene ${ }^{[86]}$

- Magnetoelectronics: $\mathrm{CoS}_{2} / \mathrm{FeS}_{2},{ }^{[87]} \mathrm{FeS}_{2} / \mathrm{FeSe}_{\mathrm{x}}{ }^{[88]}$

- Hydrogen production: $\mathrm{FeS}_{2} /$ anatase $\mathrm{TiO}_{2}{ }^{[46]}$ \& Hydrogen storage: $\mathrm{MgH}_{2}-\mathrm{FeS}_{2}{ }^{\left[{ }^{[8]}\right.}$ 


\section{WILEY-VCH}

- Lithium ion batteries (LIBs): $\mathrm{FeS}_{2} / \mathrm{CNT}^{\left[{ }^{[00]}\right.} \mathrm{FeS}_{2} @$ Carbon fibre,${ }^{[91]} \mathrm{FeS}_{2} / \mathrm{RGO}^{\left[{ }^{[92]}\right.} \mathrm{FeS}_{2} / \mathrm{N}$ -

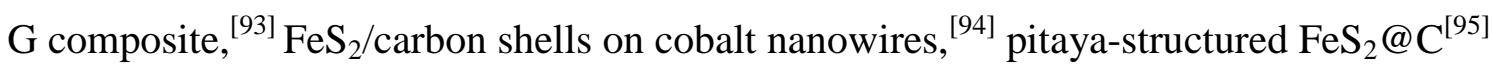

- Sodium ion batteries (SIBs): $\mathrm{FeS}_{2}$ nanosheet@ $\mathrm{Fe}_{2} \mathrm{O}_{3}{ }^{[96]}, \mathrm{Na} / \mathrm{FeS}_{2},{ }^{[57]} \mathrm{FeS}_{2} / \mathrm{rGO}-\mathrm{A}$ (reduced graphene oxide aerogel) ${ }^{[97]}$, lychee-like $\mathrm{FeS}_{2} @ \mathrm{FeSe}_{2}$ core-shell microspheres, ${ }^{[98]} \mathrm{FeS}_{2} @ \mathrm{C}$ yolk-shell nanoboxes, ${ }^{[99]} \mathrm{FeS}_{2} / \mathrm{CNT}^{[100]}$

- Supercapacitors: $\mathrm{FeS}_{2} /$ graphene ${ }^{[101]} \mathrm{FeS}_{2} / \mathrm{C}^{[102]}$

- Environmental remediation: $\mathrm{Au} @ \mathrm{FeS}_{2},{ }^{[103]} \mathrm{FeS}_{2} \mathrm{QDs} / \mathrm{SiO}_{2}$-chitosan or polypyrrole ${ }^{[104]}$

- Hydrogenation: $\mathrm{TiO}_{2} / \mathrm{FeS}_{2},{ }^{[105]} \mathrm{FeS}_{2} / \mathrm{CNT}^{[106]}$

Some elaborated examples of pyrite's composites for various applications are discussed below. $\mathrm{FeS}_{2} /$ nitrogen-doped graphene $\left(\mathrm{FeS}_{2} / \mathrm{N}-\mathrm{G}\right)$ (1:2) composite exhibited initial specific capacity of about $1051 \mathrm{mAhg}^{-1}$ at a current density of $0.1 \mathrm{C}$ with retained value $849 \mathrm{mAh} \mathrm{g}^{-1}$ after 100 cycles. The flexibility of nitrogen-doped graphene stabilized the structure of the composite electrode and prevented cubic $\mathrm{FeS}_{2}$ aggregation during cycling (Figure 5).

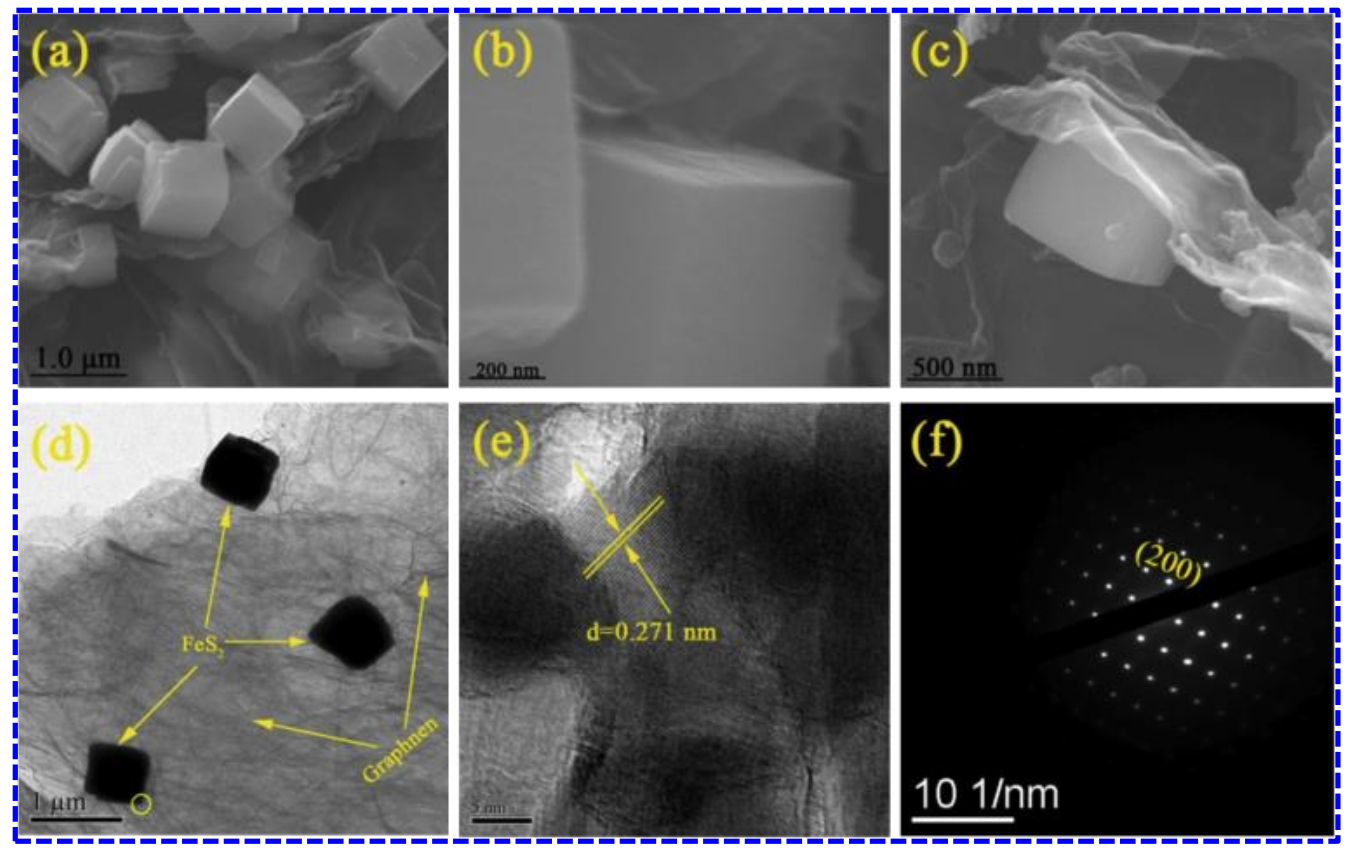

Figure 5. Microstructure of $\mathrm{FeS}_{2} / \mathrm{N}-\mathrm{G}$ (1:2) composite: (a) SEM image, (b) HRSEM image, (c) single $\mathrm{FeS}_{2} / \mathrm{N}-\mathrm{G}$ composite image, (d) TEM image, (e) HRTEM image, and (f) SAED pattern. ${ }^{[93]}$ Reproduced with permission from ref. ${ }^{[93]}$ Copyright 2014 Elsevier Ltd. 


\section{WILEY-VCH}

Pyrite phase transition metal disulfides particularly $\mathrm{FeS}_{2}$ are observed to be promising alternative electro-catalysts for both the Hydrogen Evolution Reaction (HER) and polysulfide reduction. ${ }^{[107]}$ The cost prohibitive noble metals are applied as counter electrode (CE) in regenerative liquid-junction photoelectrochemical solar cells that employ the sulfide/polysulfide redox electrolyte as the hole mediator. Such expensive electro-catalyst materials have to be replaced with high-performance earth-abundant elements to reduce the cost of electrochemical and photoelectrochemical clean hydrogen production. With moderate cobalt doping Fe:Co:S close to 0.9:0.1:2 and excellent electrical coupling to the underlying carbon nanotube, the $\mathrm{Fe}_{0.9} \mathrm{Co}_{0.1} \mathrm{~S}_{2} / \mathrm{CNT}$ (carbon nano tubes) hybrid catalyst exhibited high HER activity with low over-potential of $\sim 0.12 \mathrm{~V}\left(20 \mathrm{~mA} / \mathrm{cm}^{2}\right.$ at a loading of $\left.7 \mathrm{mg} / \mathrm{cm}^{2}\right)$, small Tafel slope of $\sim 46 \mathrm{mV} /$ decade and high long-term durability over $40 \mathrm{~h}$ in acid solutions (0.5 $\left.\mathrm{M} \mathrm{H}_{2} \mathrm{SO}_{4}\right)$. The HER activity of $\mathrm{Fe}_{0.9} \mathrm{Co}_{0.1} \mathrm{~S}_{2} / \mathrm{CNT}$ hybrid catalysts has been observed to be much better than that of $\mathrm{Fe}_{0.9} \mathrm{Co}_{0.1} \mathrm{~S}_{2} / \mathrm{rGO}$ (grapheme oxide) hybrid catalysts. The improved electrocatalytic HER activity influenced by the nanocarbon materials used for the hybrid catalysts. Iron pyrite $\left(\mathrm{FeS}_{2}\right)$ catalyst exhibited suitable adsorption energy for $\mathrm{H}_{2}$ evolution, and cobalt doping could further lower the kinetic energy barrier by promoting $\mathrm{H}-\mathrm{H}$ bond formation on two adjacently adsorbed hydrogens. ${ }^{[108]}$ Recently, n-type pyrite thin films deposited on titanium substrates displayed hydrogen photogeneration efficiencies of $\sim 8 \%$. ${ }^{[109]}$ Furthermore, Wang et al. demonstrated that the $\mathrm{FeS}_{2} / \mathrm{TiO}_{2}$ photoanode exhibited high photo response from visible to near infrared (NIR) range due to enhancement of interface charge transfer between $\mathrm{FeS}_{2}$ and $\mathrm{TiO}_{2}{ }^{[110]}$

Transition metals ( $\mathrm{Au}, \mathrm{Ag}, \mathrm{Pd}, \mathrm{Fe}, \mathrm{Ni}, \mathrm{Cu}$ etc.) are commonly used in carbon dioxide $\left(\mathrm{CO}_{2}\right)$ reduction reaction $\left(\mathrm{CO}_{2} \mathrm{RR}\right)$. Electrochemical reduction of $\mathrm{CO}_{2}$ to methanol $\left(\mathrm{CH}_{3} \mathrm{OH}\right)$ catalysed by transition metals has been proved feasible and effective in aqueous electrolytes. 


\section{WILEY-VCH}

Zhao et al. ${ }^{[111]}$ demonstrated that $\mathrm{FeS}_{2} / \mathrm{NiS}$ nanocomposite can catalyse $\mathrm{CO}_{2} \mathrm{RR}$ at an unprecedented over-potential of $280 \mathrm{mV}$ and a high $\mathrm{CH}_{3} \mathrm{OH}$ faradaic efficiency up to $64 \%$ at the potential of $\sim 0.6 \mathrm{~V}$. The $\mathrm{FeS}_{2} / \mathrm{NiS}$ catalyst performed a stable current density of $3.1 \mathrm{~mA}$ $\mathrm{cm}^{-2}$ over the 4 hours stability test. The high activity and selectivity towards $\mathrm{CO}_{2}$ electroreduction to $\mathrm{CH}_{3} \mathrm{OH}$ is probably attributed to the special ladder structure of the $\mathrm{FeS}_{2} / \mathrm{NiS}$ nanocomposite. The low-cost $\mathrm{FeS}_{2} / \mathrm{NiS}$ nanocomposite is an efficient alternative to expensive materials for the application of $\mathrm{CO}_{2}$ electroreduction in industry.

$\mathrm{Fe}_{1-\mathrm{x}} \mathrm{Co}_{\mathrm{x}} \mathrm{S}_{2}$ demonstrated onset over-potential of $\sim 50 \mathrm{mV}$ in $0.5 \mathrm{M} \mathrm{H}_{2} \mathrm{SO}_{4}$ with impressive HER performances in both practical industry wastewater and analogous wastewater simulations. Moreover degradation of anodic organic dyes methyl orange (MO), methylene blue $(\mathrm{MB})$, rhodamine $\mathrm{B}(\mathrm{RhB})$ and industry waste organic dyes were all entirely decomposed within $8 \mathrm{~min}, 18 \mathrm{~min}, 9 \mathrm{~min}$ and $4 \mathrm{~h}$ under oxidation potential $\sim 1.46,1.50,1.47$ and $1.40 \mathrm{~V}$. The acidic organic wastewater treatment and electrochemical hydrogen evolution can contribute to both the energy and environment demand. ${ }^{[112]} \mathrm{FeS}_{2} / \mathrm{FeSe}_{\mathrm{x}}$ core/shell NCs with an average $\mathrm{Fe}: \mathrm{S}: \mathrm{Se}$ atomic ratio of $36: 62: 2$ displayed transition of the magnetic behaviour from diamagnetic to ferrimagnetic, with magnetic moment measured at $0.34 \mathrm{emu}$ $\mathrm{g}^{-1}$ at $\mathrm{H}=60 \mathrm{kOe}$ for the core/shell NCs measured at $300 \mathrm{~K}$. The surface-passivation of pyrite NCs improved the functionality of bifunctional NCs that can be applied in room temperature magneto-optoelectronics and biomedicine like dual-functional magnetic resonance imaging and photothermal cancer therapy mediators respectively. ${ }^{[8]}$

$\mathrm{FeS}_{2} / \mathrm{SiO}_{2}$ microspheres activated $\mathrm{H}_{2} \mathrm{O}_{2}$ system is a promising method to enhance the degradation of ciprofloxacin (CIP) (nearly 100\%) at pH 3.0 and can be applied to other organic pollutants. The Brunauer-Emmett-Teller (BET) specific surface areas for the $\mathrm{SiO}_{2}$ microspheres $($ Mean diameter $=70 \mathrm{~nm}), \mathrm{FeS}_{2}($ Particle size $=1 \mu \mathrm{m})$ and $\mathrm{FeS}_{2} / \mathrm{SiO}_{2}($ Diameter 


\section{WILEY-VCH}

$=1$ to $2 \mu \mathrm{m}$ ) microspheres were $186.21,10.73$ and $119.15 \mathrm{~m}^{2} / \mathrm{g}$ respectively. An enhanced degradation of CIP has been attributed to a synergetic effect between adsorption and Fenton reaction in $\mathrm{FeS}_{2} / \mathrm{SiO}_{2}$ microspheres activated $\mathrm{H}_{2} \mathrm{O}_{2}$ system. ${ }^{[13]}$

Gong et al. achieved an extraordinary photo-responsivity in exceeding $\sim 10^{6} \mathrm{~A} / \mathrm{W}$ in nanocomposite $\mathrm{FeS}_{2}-\mathrm{PbS} / g r a p h e n e$ sensitizer photoconductors in an ultrabroad spectrum of ultraviolet (UV)-visible-near-infrared (NIR). These heterostructures have applications in various devices like nanohybrid optoelectronics with high performance, low cost, and scalability for commercialization. ${ }^{[114]}$

\section{Challenges: Pyrite nanocrystals in Photovoltaics (PVs)}

Following are some of the major challenges for pyrite synthesis and its application in photovoltaics.

(a) Phase pure pyrite nanocrystals or nanocrystalline pyrite

One of the most frequently reported issue related to pyrite is phase purity. There are always minor non-stoichiometric phases present in the final product that limits the optical and electrical properties of pyrite, particularly at the nanoscale. Consequently, photovoltaic properties of thin films or powder determine the performance of device. Phase pure pyrite can be synthesised by modification and upgradation of existing synthetic routes via understanding reaction mechanisms.

(b) Multi-step synthetic procedures with extended reaction times

Multistep solution synthesis of pyrite involves various steps from mixing precursors under inert environment \& using expensive vacuum line techniques to filtration, separation or purification to remove the solvent, surfactant, or by-product that ultimately reduce the yield of end product. On the other hand, post-sulfuration of precursor films also increases fabrication 


\section{WILEY-VCH}

steps as well as the process time. One-pot synthesis can significantly reduce time scales either by using single source precursors or by colloidal route.

(c) Expensive and cautious experimental methods

Post sulfuration methods involving annealing in sulfur atmosphere in the presence of inert gases needs caution to avoid any exposure and environmental hazards.

(d) Environmentally unfriendly starting materials and experimental methods

As annealing in sulfur environment is risky and require high level of expertise, the use of toxic and hazardous starting materials such as $\mathrm{H}_{2} \mathrm{~S}$ and pyrophoric iron pentacarbonyl make systems more complicated and environment unfriendly. Both, physical vapour deposition methods followed by post sulfurization or solution-based synthetic routes are expensive and mostly involve long periods of time under high temperatures.

(e) Long-time air stability of pyrite nanocrystals dispersions/colloidal solutions

Colloidal synthesis of pyrite nanocrystals provides control over nanocrystal size and uniform size distribution. Inadvertent passivation of colloidal pyrite nanocrystals with surfactants or ligands act as insulating barriers that hinder charge transport. This can be avoided either by removing ligands or by exchanging ligands. On the other hand, the surface passivation of pyrite nanocrystals with suitable ligands also shields nanocrystals from oxidation.

(f) Incompatibility with other efficient photovoltaic semiconducting materials

It is difficult to integrate pyrite with the most of the other solar materials due to lattice mismatch and difference in energy band gaps. Bandgap engineering of pyrite allows desirable integration of heterojunctions with appropriate alignment of energy levels for high performance photovoltaic devices.

(g) Inadequate routes to large area photovoltaic devices 


\section{WILEY-VCH}

Pyrite based practical devices show large leakage currents due to surface defect states and thus poor device performance. Large area fabrication of devices by spin coating, roll to roll printing or spraying requires more resources and expertise. Apart from the inherent defects of pyrite, quality and uniformity of pyrite thin films are also challenging factors to scale up pyrite photovoltaics. Pyrite photovoltaic needs more material research, interface engineering and technical understanding of large scale fabrications.

(h) Integration between theoretical, computational and experimental research work Research and development in nanotechnology is leading towards tremendous progress regarding computational programming, theoretical methods alongside experimental techniques. Physical or chemical synthetic methods for preparation of quality pyrite thin films entail such advancements as powerful tools which can eradicate deficiencies for practical photovoltaic devices.

\section{Nanocrystalline Pyrite}

At nanoscale, the properties of materials change due to the quantum confinement effect. Nanocrystalline thin films ensure exceptional physical, chemical, biological, mechanical, electrical, optical, and thermal properties. ${ }^{[115]}$ Thin films of pyrite nanocrystals (NCs) are leading trend towards photo quantization of solar energy. Quantum confinement effect not only modifies bandgap of pyrite but also enhances its electrical and electronic properties. Since bulk recombination losses are directly related to volume, and morphology of materials which facilitate the high photovoltages predicted for extremely thin films $(\leq 100 \mathrm{~nm})$ due to

confinement of charge carriers in particular direction. ${ }^{[116,117]}$ Various synthetic routes have been developed for nanocrystalline (NC) pyrite. ${ }^{[18]}$

Recent trends in experimental methodology for nanoscale synthesis of $\mathrm{FeS}_{2}$ have played a central role in improving the quality as well as properties of the $\mathrm{FeS}_{2}$ nanomaterials. 


\section{WILEY-VCH}

Magnetic field assisted hydrothermal ferrosulfide microrods growth was influenced by sulfur precursors, reaction time and reaction temperature. Microrods (diameters of $5 \mu \mathrm{m}$ and lengths 60-200 $\mu \mathrm{m}$ ) of weak paramagnetic phase marcasite (orthorhombic $\mathrm{FeS}_{2}$ ) can be produced by using thiohydracrylic acid and microrods (diameters of $15 \mu \mathrm{m}$ and lengths $150-200 \mu \mathrm{m}$ ) by using thioacetamide (TAA) as sulphur source in the presence of a magnetic field. Differing from the metastable pearl-chain-like microrods (diameters of 5.5-6 $\mu \mathrm{m}$ and lengths $75-200$ $\mu \mathrm{m}$ ) of ferromagnetic phase greigite (cubic $\mathrm{Fe}_{3} \mathrm{~S}_{4}$ ) obtained using cysteine as the sulphur precursor by applying a weak magnetic field of $450 \mathrm{G}\left(1 \mathrm{G}=10^{-4} \mathrm{Wbm}^{-2}=0.1 \mathrm{mT}\right)$. But nonmagnetic phase pyrite (cubic $\mathrm{FeS}_{2}$ ) always obtained in the absence of a magnetic field. ${ }^{[119]}$ The introduction of a magnetic field to the reaction system favourably induces the formation of magnetic phases rather than nonmagnetic ones, which could thus induce the formation of a trace amount of ferromagnetic greigite phase in the dominant $\mathrm{FeS}_{2}$ product. The synthetic procedure also plays a vital role in the morphological and structural growth of the ferrosulfide minerals, even with the assistance of a magnetic field. Surfactant free aerosol pyrolysis of $\mathrm{Fe}(\mathrm{CO})_{5}$ in sulphur atmosphere under a magnetic field of $\sim 1.5 \mathrm{mT}(15 \mathrm{G})$ produce $)$ results three-dimensional (3D) sponge like nanochain networks of iron pyrite $\left(\mathrm{FeS}_{2}\right) \cdot{ }^{[120]}$ Randomly packed $\mathrm{FeS}_{2}$ nanoparticles were produced in the absence of magnetic field, preferably, as magnetic field assembles the nanochain networks by enhancing the dipole-dipole interactions. $\mathrm{FeS}_{2}$ nanochain networks can be applied in photoelectric applications in areas of sustainable energy and environment such as counter electrode in flexible dye sensitized solar cells (DSSCs).

Zhang et al. ${ }^{[121]}$ reported $\mathrm{FeS}_{2}$ nanoclusters $(50-100 \mathrm{~nm})$ and nanocubes $(80-150 \mathrm{~nm})$ synthesised by simple colloidal chemistry route. $\mathrm{FeS}_{2}$ nanocrystals displayed strong absorption in the range of $400-1200 \mathrm{~nm}$ due to the free carrier induced localized surface 


\section{WILEY-VCH}

plasmon resonances (LSPRs). Properties mainly photovoltaic properties of $\mathrm{FeS}_{2}$ can be tuned by engineering the morphology of nanocrystals.

Various $\mathrm{FeS}_{2}$ nano-structures have been fabricated by a variety of synthetic methods including the most widely used hydrothermal/solvothermal and hot injection methods (Table 2). Nanocrystals growth in solution usually involves two primary mechanisms: coarsening (fast nucleation) and aggregation (subsequent growth). Coarsening or Ostwald ripening, ${ }^{[122]}$ is defined by the fact that the chemical potential of a particle increases with a decrease in particle size as described by Gibbs-Thompson equation. ${ }^{[123]}$ In Ostwald ripening ${ }^{[124]}$ process, larger particles grow on the expense of smaller ones. LaMer theory ${ }^{[125,126]}$ is typically used to explain hot-injection synthesis of nanoparticles characterized by diffusion-limited growth. First step involves "burst" of nucleation and second step is diffusion-limited growth of nucleates that is controlled only by the concentration of reactants in solution. In this reaction, the amorphous phase is fully converted to crystalline particles within a few minutes. Moreover, in the oriented attachment growth process, the reaction temperature dominates the collision and the coalescence which is attributed to the particle's medium- and short-range interactions, such as Van der Waals forces and dipole-dipole interaction forces.

There are several factors that play a key role in synthesis of the phase pure pyrite NCs as well as their photoconductivity $e . g$., precursors (iron source \& sulfur source providing $\boldsymbol{S}_{2}^{2-}$ units), precursor ratios (Fe:S), reaction temperature, reaction time, precursor concentration, $\mathrm{pH}$ of reaction solution, solvents, surfactants and ligands. ${ }^{[127]}$ Recently Rhodes et al. ${ }^{[128]}$ studied the effect of sulfur sources using dialkyl disulfides, alkyl thiols, and dialkyl disulfides (allyl, benzyl, tert-butyl, and phenyl) on iron sulfide phases via colloidal route. Reactivity of sulfur source determined the phase selection between pyrite $\left(\mathrm{FeS}_{2}\right)$, greigite $\left(\mathrm{Fe}_{3} \mathrm{~S}_{4}\right)$, and pyrrhotite $\left(\mathrm{Fe}_{7} \mathrm{~S}_{8}\right)$ as a function of the $\mathrm{C}-\mathrm{S}$ bond strength where sulfur-rich phases were 


\section{WILEY-VCH}

yielded by weaker $\mathrm{C}-\mathrm{S}$ bonds. All precursors decomposed differently following the different reaction paths. Alkylamine is essential for the phase selective synthesis of pyrite using diallyl sulfide as the sulfur precursor (Figure 6).

Hot injection method (HIM) and hydrothermal method (HTM) or solvothermal method (STM) are the most commonly used synthetic methods for synthesis of pyrite summarised in Table 2 and are comprehensively discussed in next sections. 


\section{WILEY-VCH}

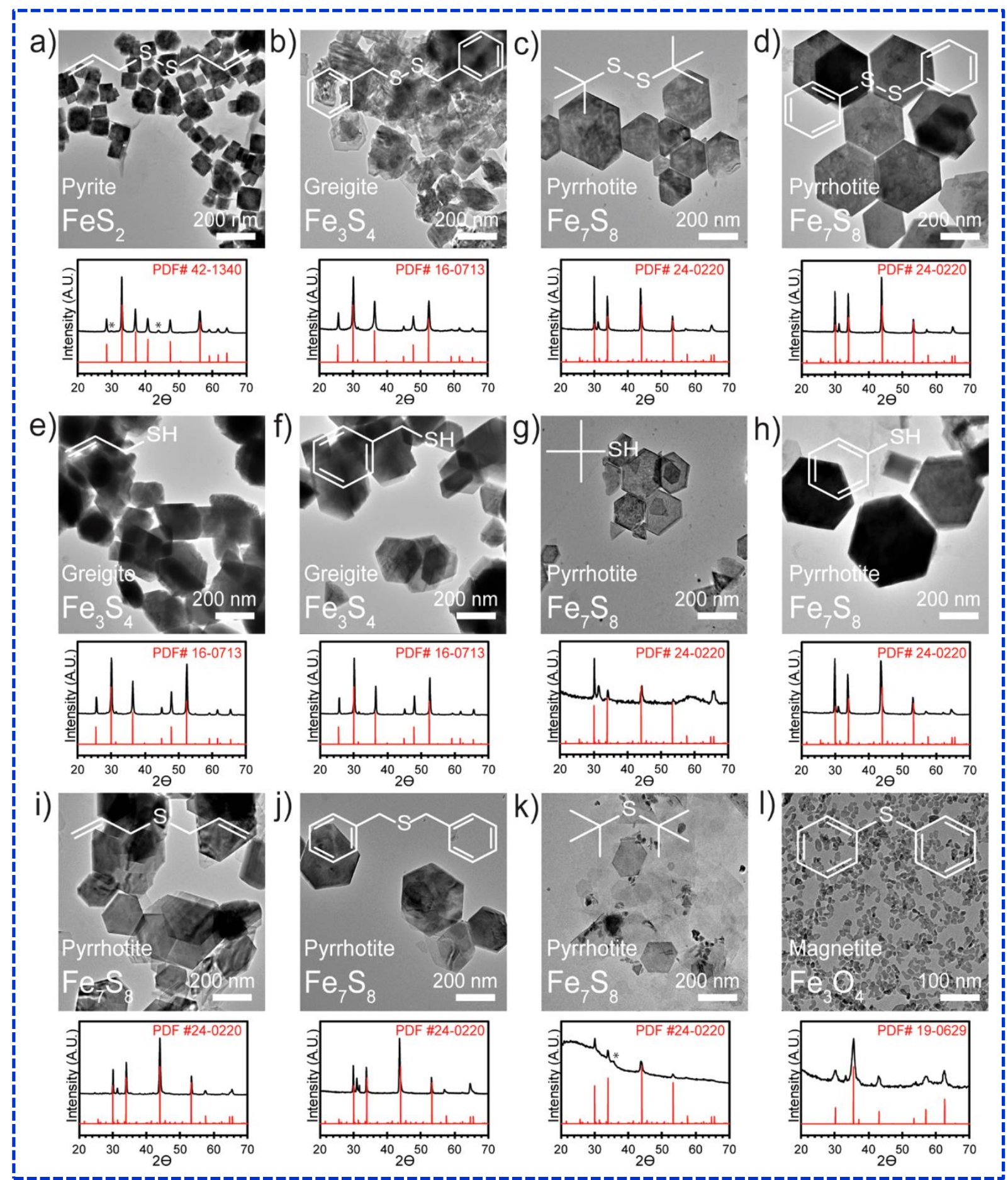

Figure 6. Figure 1. Representative TEM images and XRD patterns for products prepared with sulfur precursors of a) Allyl-SS-Allyl (*noted peaks from pyrrhotite impurity), b) Bz-SS-Bz, c) t-Bu-SS-t-Bu, d) Ph-SS-Ph, e) Allyl-SH, f) Bz-SH, g) t-Bu-SH, h) Ph-SH, (i) Allyl-S-Allyl, j) $\mathrm{Bz}-\mathrm{S}-\mathrm{Bz}, \mathrm{k}) \mathrm{t}-\mathrm{Bu}-\mathrm{St}-\mathrm{Bu}$ (* peak is from magnetite impurity phase), and $\mathrm{l}) \mathrm{Ph}-\mathrm{S}-\mathrm{Ph} .{ }^{[128]}$ Reproduced with permission from ref. ${ }^{[128]}$. Copyright 2017 American Chemical Society. 


\section{WILEY-VCH}

Table 2 Synthetic methods for nanocrystalline pyrite $\left(\mathrm{FeS}_{2}\right)^{\dagger}$ (2005 - Present)

\begin{tabular}{|c|c|c|c|c|c|c|c|c|}
\hline Method & Precursors & $\begin{array}{l}\text { Reaction } \\
\text { Temp. }\left({ }^{\circ} \mathrm{C}\right) \\
\text { (time) }\end{array}$ & $\begin{array}{l}\text { Solvent/ } \\
\text { Surfactant/ } \\
\text { Ligand }\end{array}$ & Morphology & Size (nm) & $\begin{array}{l}\text { Absorption } \\
\text { peaks / } \\
\text { Bandgap }\end{array}$ & $\begin{array}{l}\text { SEM/TEM } \\
\text { Image }\end{array}$ & Ref. \\
\hline $\begin{array}{l}\text { HTM } \\
\text { (capacity } \\
50 \mathrm{~mL} \text { ) }\end{array}$ & $\begin{array}{l}\mathrm{FeE}_{3} \\
(0.4 \mathrm{~g})\end{array}$ & $\begin{array}{l}180 \\
(12 \mathrm{~h})\end{array}$ & $\mathrm{H}_{2} \mathrm{O}(40 \mathrm{~mL})$ & Nanocubes & $500 \mathrm{~nm}$ & $\begin{array}{l}1420 \mathrm{~nm} \\
(0.87 \mathrm{eV})\end{array}$ & & {$[129]$} \\
\hline $\begin{array}{l}\text { STM } \\
\text { (capacity } \\
25 \mathrm{~mL} \text { ) }\end{array}$ & $\begin{array}{l}\mathrm{FeCl}_{2}(0.002 \mathrm{~mol})+ \\
\mathrm{Na}_{2} \mathrm{~S}_{2} \mathrm{O}_{3}(0.002 \mathrm{~mol})\end{array}$ & $\begin{array}{l}135-140 \\
(1-48 \mathrm{~h})\end{array}$ & $\begin{array}{l}\text { Benzene ( } 95 \% \\
\text { of capacity) }\end{array}$ & Nanoweb & $\begin{array}{l}\text { NW's D = } \\
40 \mathrm{~nm} \\
\text { NWeb, } \rho= \\
10^{10} \mathrm{~cm}^{-2}\end{array}$ & $\begin{array}{l}220 \mathrm{~nm}(5.64 \\
\mathrm{eV}), 263 \\
\mathrm{~nm}(4.71 \mathrm{eV}), \\
\text { and } 279 \mathrm{~nm} \\
(4.44 \mathrm{eV})\end{array}$ & & {$[130]$} \\
\hline $\begin{array}{l}\text { HTM } \\
\text { (capacity } \\
20 \mathrm{~mL} \text { ) }\end{array}$ & $\begin{array}{l}\text { Fe foil } \\
(0.127 \mathrm{~mm} \times 1.5 \mathrm{~cm} \times \\
0.5 \mathrm{~cm})+ \\
\mathrm{S}(1 \mathrm{mmol})\end{array}$ & $\begin{array}{l}160 \\
(12 \mathrm{~h})\end{array}$ & $\begin{array}{l}15 \mathrm{~mL} \text { of } 6.6 \\
\mathrm{v} / \mathrm{v} \% \text { aqueous } \\
\text { hydrazine } \\
\text { solution }\end{array}$ & Nanosheets & $30 \mathrm{~nm}$ & $\begin{array}{l}\text { conversion } \\
\text { efficiency }(\eta) \\
\text { of } 0.93 \%\end{array}$ & & {$[131]$} \\
\hline $\begin{array}{l}\text { HTM } \\
\text { (capacity } \\
125 \mathrm{~mL} \text { ) }\end{array}$ & $\begin{array}{l}\text { DDPA } \\
(40 \mathrm{~mL}, 0.12 \mathrm{M})+ \\
\mathrm{FeCl}_{3}(20 \mathrm{~mL}, 0.08 \mathrm{M})\end{array}$ & $\begin{array}{l}200 \\
(4-48 \mathrm{~h})\end{array}$ & CTAB & $\begin{array}{l}\text { Quasi-cubic } \\
\text { Nanocrystals }\end{array}$ & $100 \mathrm{~nm}$ & $0.95 \mathrm{eV}$ & & {$[132]$} \\
\hline $\begin{array}{l}\text { STM } \\
\text { (capacity } \\
50 \mathrm{~mL} \text { ) }\end{array}$ & $\begin{array}{l}\mathrm{FeCl}_{2} .4 \mathrm{H}_{2} \mathrm{O}(0.14 \mathrm{~g})+ \\
\mathrm{S}(0.2 \mathrm{~g})+ \\
\mathrm{NaOH}(1.5 \mathrm{M}, 5 \mathrm{~mL})\end{array}$ & $\begin{array}{l}180 \\
(12 \mathrm{~h})\end{array}$ & $\begin{array}{l}\text { TX-100 (8 } \\
\mathrm{mL})+ \\
\mathrm{EG}(22 \mathrm{~mL})\end{array}$ & $\begin{array}{l}\text { Micro- } \\
\text { octahedron }\end{array}$ & $300 \mathrm{~nm}$ & - & & {$[133]$} \\
\hline HIM & $\begin{array}{l}\mathrm{FeCl}_{2} .4 \mathrm{H}_{2} \mathrm{O} \\
(100 \mathrm{mg}, 0.5 \mathrm{~mol})+ \\
\mathrm{S}(96 \mathrm{mg}, 3 \mathrm{mmol})\end{array}$ & $\begin{array}{l}220 \\
(3 \mathrm{~h})\end{array}$ & $\begin{array}{l}\text { DPE }(5 \mathrm{~mL}) \\
\text { ODA }(10 \mathrm{~g}, \\
0.14 \mathrm{~mol})\end{array}$ & $\begin{array}{l}\text { oblate and } \\
\text { spheroidal } \\
\text { single crystals }\end{array}$ & $5-20 \mathrm{~nm}$ & $\sim 0.9 \mathrm{eV}$ & & {$[134]$} \\
\hline HIM & $\begin{array}{l}\mathrm{FeCl}_{2} \\
(254 \mathrm{mg}, 2 \mathrm{mmol})+ \\
6 \mathrm{~S}\end{array}$ & $\begin{array}{l}220 \\
(0.33 \mathrm{~h})\end{array}$ & $\mathrm{OA}(12 \mathrm{~mL})$ & Nanodendrite & $10 \mathrm{~nm}$ & $0.9 \mathrm{eV}$ & & {$[135]$} \\
\hline $\begin{array}{l}\text { STM } \\
\text { (capacity } \\
50 \mathrm{~mL} \text { ) }\end{array}$ & $\begin{array}{l}\mathrm{FeCl}_{3} \cdot 6 \mathrm{H}_{2} \mathrm{O}(1 \mathrm{mmol}) \\
+ \\
\text { urea }(0.3 \mathrm{~g})+\mathrm{S}(0.2 \mathrm{~g})\end{array}$ & $\begin{array}{l}160 \\
(12 \mathrm{~h})\end{array}$ & $\begin{array}{l}\text { DMF }(15 \mathrm{~mL}) \\
+ \\
\text { EG }(20 \mathrm{~mL})\end{array}$ & Nano flakes & $50 \mathrm{~nm}$ & - & & {$[136]$} \\
\hline MW & $\begin{array}{l}\mathrm{FeSO}_{4} \cdot 7 \mathrm{H}_{2} \mathrm{O} \\
(0.556 \mathrm{~g}, 2 \mathrm{mmol})+ \\
\mathrm{S}(0.128 \mathrm{~g}, 4 \mathrm{mmol})\end{array}$ & $\begin{array}{l}\text { MW power } \\
\text { of } 70 \% \text { for } \\
(1 \mathrm{~h})\end{array}$ & $\begin{array}{l}\text { PVP K30 }(0.6 \\
\mathrm{g})+ \\
\text { EG }(22 \mathrm{~mL})\end{array}$ & $\begin{array}{l}\text { Micro- } \\
\text { spherolites }\end{array}$ & $2.7 \mu \mathrm{m}$ & - & & {$[137]$} \\
\hline
\end{tabular}




\section{WILEY-VCH}

\begin{tabular}{|c|c|c|c|c|c|c|c|c|}
\hline Method & Precursors & $\begin{array}{l}\text { Reaction } \\
\text { Temp. }\left({ }^{\circ} \mathrm{C}\right) \\
\text { (time) }\end{array}$ & $\begin{array}{l}\text { Solvent/ } \\
\text { Surfactant/ } \\
\text { Ligand }\end{array}$ & Morphology & Size (nm) & $\begin{array}{l}\text { Absorption } \\
\text { peaks / } \\
\text { Bandgap }\end{array}$ & $\begin{array}{l}\text { SEM/TEM } \\
\text { Image }\end{array}$ & Ref. \\
\hline HIM & $\begin{array}{l}\mathrm{FeCl}_{2} \cdot 3 \mathrm{H}_{2} \mathrm{O}(100 \mathrm{mg}) \\
+ \\
\mathrm{S}(96 \mathrm{mg})\end{array}$ & $220(3 \mathrm{~h})$ & $\begin{array}{l}\text { ODA }(10 \mathrm{~g})+ \\
\text { DPE }(5 \mathrm{~mL})+ \\
\text { ODA }\end{array}$ & Nanocrystals & $\begin{array}{l}14.8 \pm 3.6 \\
\mathrm{~nm}\end{array}$ & $\begin{array}{l}\text { optical } \\
\text { absorption } \\
\text { edge near } 1.0 \\
\text { eV }\end{array}$ & & {$[138]$} \\
\hline HIM & $\begin{array}{l}\mathrm{FeCl}_{2} .3 \mathrm{H}_{2} \mathrm{O} \\
(126.8 \mathrm{mg}, 1 \mathrm{mmol})+ \\
\mathrm{S} \\
(65.7 \mathrm{mg}, 2.05 \mathrm{mmol})\end{array}$ & $250(3 \mathrm{~h})$ & $\begin{array}{l}\text { HDA }(10 \mathrm{~g}) \\
+ \\
\text { OA }(15 \mathrm{~mL})\end{array}$ & Nanocubes & $37 \mathrm{~nm}$ & $1.1 \mathrm{eV}$ & & {$[139]$} \\
\hline HIM & $\mathrm{Fe}(\mathrm{CO})_{5}$ & $\begin{array}{l}120-240 \\
(0.05-9 \mathrm{~h})\end{array}$ & OLA & Nanoplates & $150 \mathrm{~nm}$ & $\begin{array}{l}895 \mathrm{~nm} \\
(1.38 \mathrm{eV})\end{array}$ & & [140] \\
\hline Sulfuration & Steel foil & $350(2 \mathrm{~h})$ & - & Nanowires & $\begin{array}{l}\mathrm{D}= \\
4-10 \mathrm{~nm} \\
\mathrm{~L}>2 \mu \mathrm{m}\end{array}$ & - & & {$[141]$} \\
\hline HIM & $\begin{array}{l}\mathrm{FeCl}_{2} \cdot 4 \mathrm{H}_{2} \mathrm{O} \\
(0.259 \mathrm{~g}, 1.30 \mathrm{~mol})+ \\
\mathrm{Na}_{2} \mathrm{~S}_{2} \mathrm{O}_{3} \cdot 5 \mathrm{H}_{2} \mathrm{O} \\
(1.45 \mathrm{~g}, 5.85 \mathrm{mmol})\end{array}$ & $\begin{array}{l}139 \\
(2-12 \mathrm{~h})\end{array}$ & $\begin{array}{l}\text { DMSO (90 } \\
\mathrm{mL})+ \\
\text { TGA } \\
\text { (stabilizer) }\end{array}$ & $\begin{array}{l}\text { Nanoparticles } \\
\text { Nanowires }\end{array}$ & $\begin{array}{l}3-10 \mathrm{~nm} \\
\mathrm{~L}=2-5 \mu \mathrm{m}, \\
\mathrm{D}= \\
80-120 \\
\mathrm{~nm} .\end{array}$ & $400-600 \mathrm{~nm}$ & & [79] \\
\hline & & & & Nanosheets & $\begin{array}{l}\text { LD } \\
=100-200\end{array}$ & & & \\
\hline Sulfuration & $\begin{array}{l}\mathrm{FeCl}_{2} \cdot 4 \mathrm{H}_{2} \mathrm{O}(5 \mathrm{mg}) \text { or } \\
\mathrm{FeBr}_{2}(5 \mathrm{mg})\end{array}$ & $\begin{array}{l}415 \\
(0.5-0.75 \mathrm{~h}) \\
\mathrm{S}_{\mathrm{x}}=300 \\
\text { Torr }\end{array}$ & - & Nanowire & - & - & $200 \mathrm{~nm}$ & {$[142]$} \\
\hline & & & & Nanoplate & & & & \\
\hline
\end{tabular}




\section{WILEY-VCH}

\begin{tabular}{|c|c|c|c|c|c|c|c|c|}
\hline Method & Precursors & $\begin{array}{l}\text { Reaction } \\
\text { Temp. }\left({ }^{\circ} \mathrm{C}\right) \\
\text { (time) }\end{array}$ & $\begin{array}{l}\text { Solvent/ } \\
\text { Surfactant/ } \\
\text { Ligand }\end{array}$ & Morphology & Size (nm) & $\begin{array}{l}\text { Absorption } \\
\text { peaks / } \\
\text { Bandgap }\end{array}$ & $\begin{array}{l}\text { SEM/TEM } \\
\text { Image }\end{array}$ & Ref. \\
\hline HIM & $\begin{array}{l}\mathrm{FeCl}_{3} \\
(81 \mathrm{mg}, 0.5 \mathrm{mmol})+ \\
\mathrm{S}(96 \mathrm{~g}, 3 \mathrm{mmol})\end{array}$ & $\begin{array}{l}220 \\
(\mathrm{~h})\end{array}$ & $\begin{array}{l}\text { OA }(15 \mathrm{~mL})+ \\
\operatorname{HDSA}(328 \\
\mathrm{mg}, 1 \mathrm{mmol})\end{array}$ & Nanocubes & $80 \mathrm{~nm}$ & $\begin{array}{l}1.00 \pm 0.11 \\
\mathrm{eV}\end{array}$ & & {$[143]$} \\
\hline $\begin{array}{l}\text { Thermo- } \\
\text { lysis }\end{array}$ & $\begin{array}{l}{\left[\mathrm{Fe}\left(\mathrm{S}_{2} \mathrm{COMe}\right)_{3}\right] \text { or }} \\
{\left[\mathrm{Fe}\left(\mathrm{S}_{2} \mathrm{COEt}\right)_{3}\right]} \\
(0.5 \mathrm{~g}, 1.32 \mathrm{mmol})\end{array}$ & $\begin{array}{l}230 \\
(1 \mathrm{~h})\end{array}$ & HDA $(15 \mathrm{~mL})$ & $\begin{array}{l}\text { Plate like } \\
\text { crystallites }\end{array}$ & $\begin{array}{l}\mathrm{L}= \\
13.6-31 \\
\mathrm{~nm} \\
\mathrm{~W}= \\
8-26 \mathrm{~nm}\end{array}$ & - & & {$[144]$} \\
\hline HIM & $\begin{array}{l}\mathrm{FeCl}_{3}(0.5 \mathrm{mmol})+ \\
\mathrm{S}(4 \mathrm{mmol})\end{array}$ & $\begin{array}{l}70 \\
(1 \mathrm{~h})\end{array}$ & $\begin{array}{l}\text { DPE }(5 \mathrm{~mL})+ \\
\text { ODA }(12 \mathrm{~g})\end{array}$ & Nanospheres & $2 \mathrm{~nm}$ & visible to NIR & & {$[145]$} \\
\hline $\begin{array}{l}\text { STM } \\
\text { (capacity } \\
100 \mathrm{~mL} \text { ) }\end{array}$ & $\begin{array}{l}\mathrm{FeSO}_{4} .7 \mathrm{H}_{2} \mathrm{O}(13.9 \mathrm{~g}) \\
+\mathrm{NH}_{2} \mathrm{CSNH}_{2}(3.8 \mathrm{~g}) \\
+\mathrm{S}(1.2 \mathrm{~g})\end{array}$ & $\begin{array}{l}180 \\
(24 \mathrm{~h})\end{array}$ & $\begin{array}{l}\mathrm{DI} \mathrm{H}_{2} \mathrm{O}(25 \\
\mathrm{mL})+ \\
\text { ethanol }(25 \\
\mathrm{mL})\end{array}$ & $\begin{array}{l}\text { Bud-like } \\
\text { microplates }\end{array}$ & $2.0-3.0 \mu \mathrm{m}$ & - & & {$[146]$} \\
\hline HIM & $\begin{array}{l}\mathrm{FeCl}_{3}(0.5 \mathrm{mmol})+ \\
\mathrm{S}(4 \mathrm{mmol})\end{array}$ & $\begin{array}{l}220 \\
(1.5 \mathrm{~h})\end{array}$ & $\begin{array}{l}\text { DPE }(5 \mathrm{~mL})+ \\
\text { ODA }(12 \mathrm{~g})\end{array}$ & $\begin{array}{l}\text { Nanosheets } \\
\text { and } \\
\text { Nanocrystals }\end{array}$ & $\begin{array}{l}\mathrm{D}=13.4 \mathrm{~nm} \\
\mathrm{~L}=47.5 \\
\mathrm{~nm}\end{array}$ & - & & [63] \\
\hline $\begin{array}{l}\text { STM } \\
\text { (capacity } \\
50 \mathrm{~mL} \text { ) }\end{array}$ & $\begin{array}{l}\mathrm{MS} @ \mathrm{Cu}^{2+} / \mathrm{PE}+ \\
\mathrm{FeCl}_{3} \cdot 6 \mathrm{H}_{2} \mathrm{O}(0.541 \mathrm{~g}) \\
+\mathrm{Na}_{2} \mathrm{~S}_{2} \mathrm{O}_{3} .5 \mathrm{H}_{2} \mathrm{O} \\
(0.745 \mathrm{~g})\end{array}$ & $\begin{array}{l}200 \\
(20 \mathrm{~h})\end{array}$ & $\begin{array}{l}\mathrm{H}_{2} \mathrm{O}(3 \mathrm{~mL})+ \\
\mathrm{n} \text {-pentanol }(3 \\
\mathrm{mL})+ \\
\text { cyclohexane } \\
(30 \mathrm{~mL})\end{array}$ & $\begin{array}{l}\text { Flake-like } \\
\text { microshperes } \\
(\mathrm{MS} @ \mathrm{CuO} @ \\
\left.\mathrm{FeS}_{2}\right)\end{array}$ & $\sim 1.3 \mu \mathrm{m}$ & $\begin{array}{l}230 \text { and } 1385 \\
\mathrm{~nm}\end{array}$ & & {$[82]$} \\
\hline HIM & $\begin{array}{l}\mathrm{FeCl}_{3}(0.45 \mathrm{mmol})+ \\
\mathrm{S} / \mathrm{OLA}(0.6 \mathrm{M}, 5 \mathrm{~mL}) \\
+\mathrm{Zn}\left(\mathrm{C}_{18} \mathrm{H}_{37} \mathrm{COO}\right)_{2} \\
(0.05 \mathrm{mmol})\end{array}$ & $\begin{array}{l}220 \\
(2 \mathrm{~h})\end{array}$ & $\begin{array}{l}\text { TOPO }(0.3 \\
\text { mmol })+ \\
\text { OLA }(10 \mathrm{~mL})\end{array}$ & Nanocrystals & $19 \pm 6.5$ & - & & {$[147]$} \\
\hline HIM & $\begin{array}{l}\mathrm{FeCl}_{2} .4 \mathrm{H}_{2} \mathrm{O}(600 \mathrm{mg}) \\
+\mathrm{S}(600 \mathrm{mg})\end{array}$ & $\begin{array}{l}210 \\
(1 \mathrm{~h})\end{array}$ & $\begin{array}{l}\text { ETA }(40 \mathrm{~mL}) \\
+ \\
\text { DPE }(15 \mathrm{~mL})\end{array}$ & Nano husk & $6 \mathrm{~nm}$ & $\begin{array}{l}920 \mathrm{~nm} \\
(1.34 \mathrm{eV})\end{array}$ & & {$[148]$} \\
\hline HIM & $\begin{array}{l}\mathrm{FeCl}_{2} .4 \mathrm{H}_{2} \mathrm{O}(500 \mathrm{mg}) \\
+\mathrm{S}(500 \mathrm{mg})\end{array}$ & $\begin{array}{l}215 \\
(1 \mathrm{~h})\end{array}$ & DDA $(40 \mathrm{~mL})$ & Quantum dots & $5 \mathrm{~nm}$ & $0.99 \mathrm{eV}$ & & [149] \\
\hline
\end{tabular}




\section{WILEY-VCH}

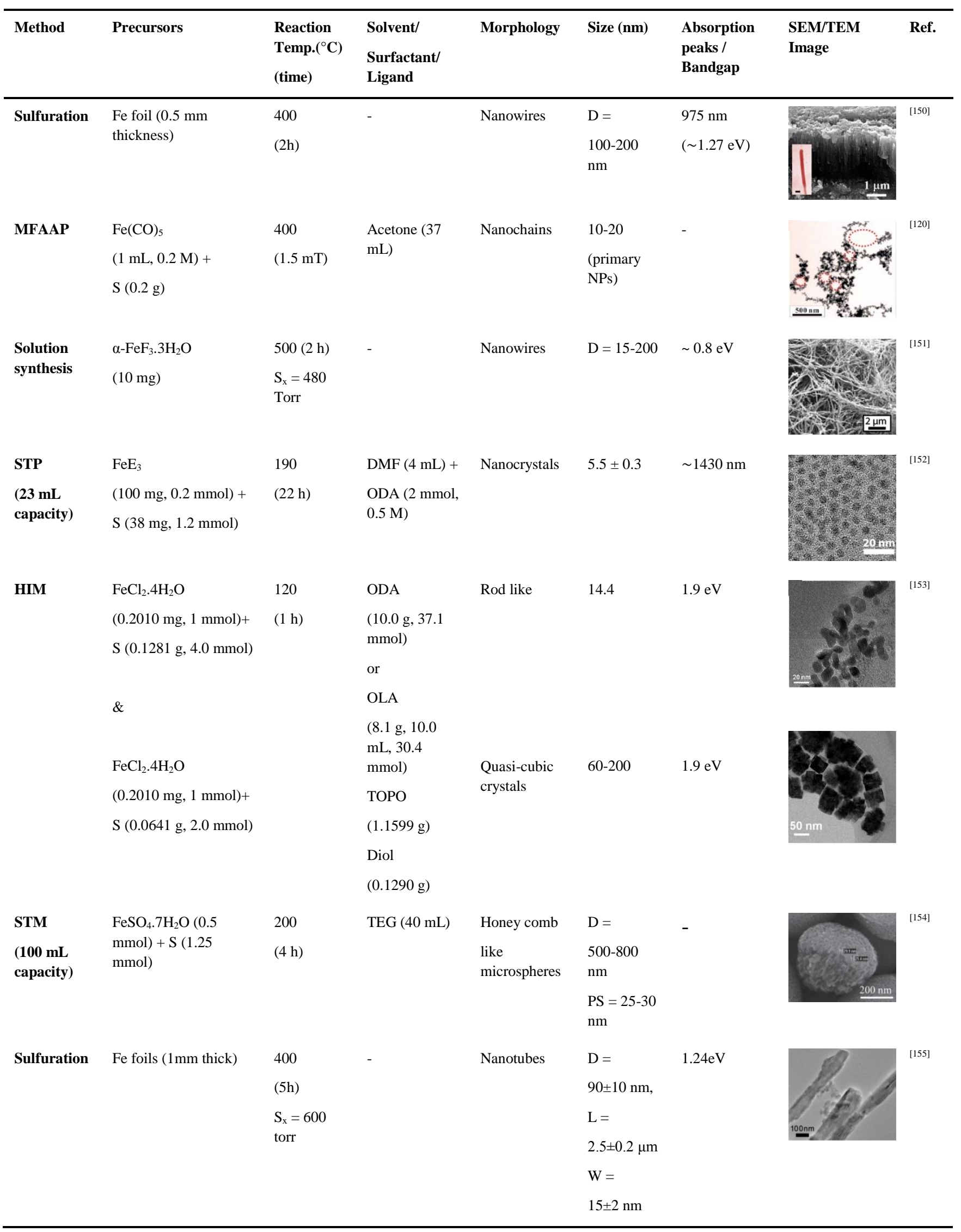




\section{WILEY-VCH}

\begin{tabular}{|c|c|c|c|c|c|c|c|c|}
\hline Method & Precursors & $\begin{array}{l}\text { Reaction } \\
\text { Temp. }\left({ }^{\circ} \mathrm{C}\right) \\
\text { (time) }\end{array}$ & $\begin{array}{l}\text { Solvent/ } \\
\text { Surfactant/ } \\
\text { Ligand }\end{array}$ & Morphology & Size (nm) & $\begin{array}{l}\text { Absorption } \\
\text { peaks / } \\
\text { Bandgap }\end{array}$ & $\begin{array}{l}\text { SEM/TEM } \\
\text { Image }\end{array}$ & Ref. \\
\hline $\begin{array}{l}\text { STM } \\
(100 \mathrm{~mL} \\
\text { capacity })\end{array}$ & $\begin{array}{l}\mathrm{FeSO}_{4} .7 \mathrm{H}_{2} \mathrm{O}(2 \mathrm{mmol}) \\
+ \text { urea }(10 \mathrm{mmol})+ \\
\mathrm{S}(12.5 \mathrm{mmol})\end{array}$ & $\begin{array}{l}180 \\
(12 \mathrm{~h})\end{array}$ & $\begin{array}{l}\mathrm{DMF}(30 \mathrm{~mL}) \\
+ \\
\text { EG }(40 \mathrm{~mL})\end{array}$ & Microspheres & $\begin{array}{l}\text { NPs }= \\
200 \mathrm{~nm} \\
\mathrm{D}=10 \mu \mathrm{m}\end{array}$ & - & & [156] \\
\hline $\begin{array}{l}\text { STM } \\
(100 \mathrm{~mL} \\
\text { capacity })\end{array}$ & $\begin{array}{l}\mathrm{FeE}_{3}(100 \mathrm{mg}, 0.2 \\
\mathrm{mmol})+ \\
\mathrm{S}(32 \mathrm{mg}, 2 \mathrm{mmol})+ \\
\mathrm{G}(0.54 \mathrm{~g}, 0.5 \mathrm{M})\end{array}$ & $\begin{array}{l}160-190 \\
(4-7 \mathrm{~h})\end{array}$ & $\begin{array}{l}\mathrm{DMF}(4 \mathrm{~mL})+ \\
\mathrm{H}_{2} \mathrm{O}(3 \mathrm{~mL}) \\
-\end{array}$ & Nanocrystals & $13 \pm 3 \mathrm{~nm}$ & - & & {$[157]$} \\
\hline HIM & $\begin{array}{l}\mathrm{FeBr}_{2}(1.49 \mathrm{mmol}, 321 \\
\mathrm{mg})+\mathrm{S}(288 \mathrm{mg}, 8.98 \\
\mathrm{mmol})\end{array}$ & 220 & $\begin{array}{l}\text { OLA }(45 \mathrm{~mL}) \\
+ \\
\text { TOPO }(1.16 \mathrm{~g}, \\
3 \mathrm{mmol})+ \\
\operatorname{Diol}(3.2 \\
\mathrm{mmol}, 0.4 \mathrm{~mL})\end{array}$ & Nanocubes & $70-150$ & $\begin{array}{l}\sim 1.3 \mathrm{eV} \text { direct } \\
\text { and } \sim 0.95 \mathrm{eV} \\
\text { indirect }\end{array}$ & & [158] \\
\hline $\begin{array}{l}\text { STM } \\
(100 \mathrm{~mL} \\
\text { capacity })\end{array}$ & 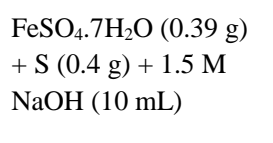 & $\begin{array}{l}180 \\
(12 \mathrm{~h})\end{array}$ & $\begin{array}{l}\text { TX-100 (16 } \\
\mathrm{mL})+ \\
\mathrm{EG}(44 \mathrm{~mL})\end{array}$ & Nanocubes & $800-1000$ & - & & [159] \\
\hline HIM & $\begin{array}{l}\mathrm{FeCl}_{2}(6.7 \mathrm{mmol})+ \\
\mathrm{S}(40 \mathrm{mmol})\end{array}$ & $\begin{array}{l}220 \\
(0.33 \mathrm{~h})\end{array}$ & $\mathrm{OA}(160 \mathrm{~mL})$ & Nanocubes & $\begin{array}{l}50-100 \\
n m\end{array}$ & - & & {$[160]$} \\
\hline HTM & $\begin{array}{l}\mathrm{FeSO}_{4} .7 \mathrm{H}_{2} \mathrm{O}(3.2 \mathrm{~g}) \\
+\mathrm{Na}_{2} \mathrm{~S}_{2} \mathrm{O}_{3}(4 \mathrm{~g})+ \\
\mathrm{S}(0.7 \mathrm{~g})\end{array}$ & $\begin{array}{l}200 \\
(24 \mathrm{~h})\end{array}$ & CTAB $(0.01 \mathrm{~g})$ & Nanoplates & $\begin{array}{l}\mathrm{LD}=70 \\
\mathrm{~nm} \\
\mathrm{~T}=8 \mathrm{~nm}\end{array}$ & $0.97 \mathrm{eV}$ & & {$[161]$} \\
\hline $\begin{array}{l}\text { Ultrasonic } \\
(20 \mathrm{kHz})\end{array}$ & $\begin{array}{l}\mathrm{FeSO}_{4} \cdot 7 \mathrm{H}_{2} \mathrm{O}(2.68 \mathrm{~g}) \\
+\mathrm{Na}_{2} \mathrm{~S}_{2} \mathrm{O}_{3} \cdot 5 \mathrm{H}_{2} \mathrm{O} \\
(6.68 \mathrm{~g})\end{array}$ & $\begin{array}{l}70 \\
(10 \mathrm{~min})\end{array}$ & Ethanol & Nanocrystals & - & - & & {$[162]$} \\
\hline Sulfuration & meso- $\mathrm{Fe}_{2} \mathrm{O}_{3}$ & $\begin{array}{l}250 \\
(12 \mathrm{~h}) \\
\mathrm{S}=200 \\
\mathrm{mg}\end{array}$ & - & Mesoporous & $\begin{array}{l}\text { pore size } \\
4-7 \mathrm{~nm}\end{array}$ & - & b & {$[163]$} \\
\hline
\end{tabular}

$\dagger$ Hot injection method: HIM; Solvothermal method: STM; Hydrothermal method: HTM; microwave: MW; Magnetic field assisted- aerosol pyrolysis: MFAAP; octadecylamine: ODA; diphenyl ether: DPE; oleylamine: OLA; trioctylphosphine oxide: TOPO; hexadecylamine: HDA; 1-octadecence: ODE; oleic acid: OA; 1-hexadecanesulfonic acid: HDSA; dimethyl sulfoxide: DMSO; thioglycolic acid: TGA; cetyltrimethylammonium bromide: CTAB; 1,2 hexadecanediol: diol; ethylene glycol: EG; triethylene glycol: TEG; poly(vinylpyrrolidone): PVP; triton X-100: TX-100; N, Ndimethytformamide: DMF; Ethanolamine: ETA; dodecylamine: DDA; diethyl dithiophosphate ammonium salt: DDPA; iron diethyldithiocarbamate: $\mathbf{F e E}_{3}$; Glucose: G; Sulfuration temperature: $\mathbf{S}_{\mathbf{x}}$ : Diameter: D; Length: L; Width: W; Thickness: T; Lateral dimensions: LD; Pore size: PS 


\section{WILEY-VCH}

\subsection{Hot Injection Method (HIM)}

Colloidal $\mathrm{FeS}_{2}$ nanocrystals are preferred for large-scale, roll-to-roll fabrication or inkjet printing for energy conversion devices. Mostly, $\mathrm{FeS}_{2} \mathrm{NC}$ inks have been synthesized using the hot injection method under air-free conditions. HIM typically involves the injection of a room temperature solution of sulfur precursor into water free solution of halogenated iron precursor at temperature in the range of 120 to $250{ }^{\circ} \mathrm{C}$ under air free environment (Figure 7).

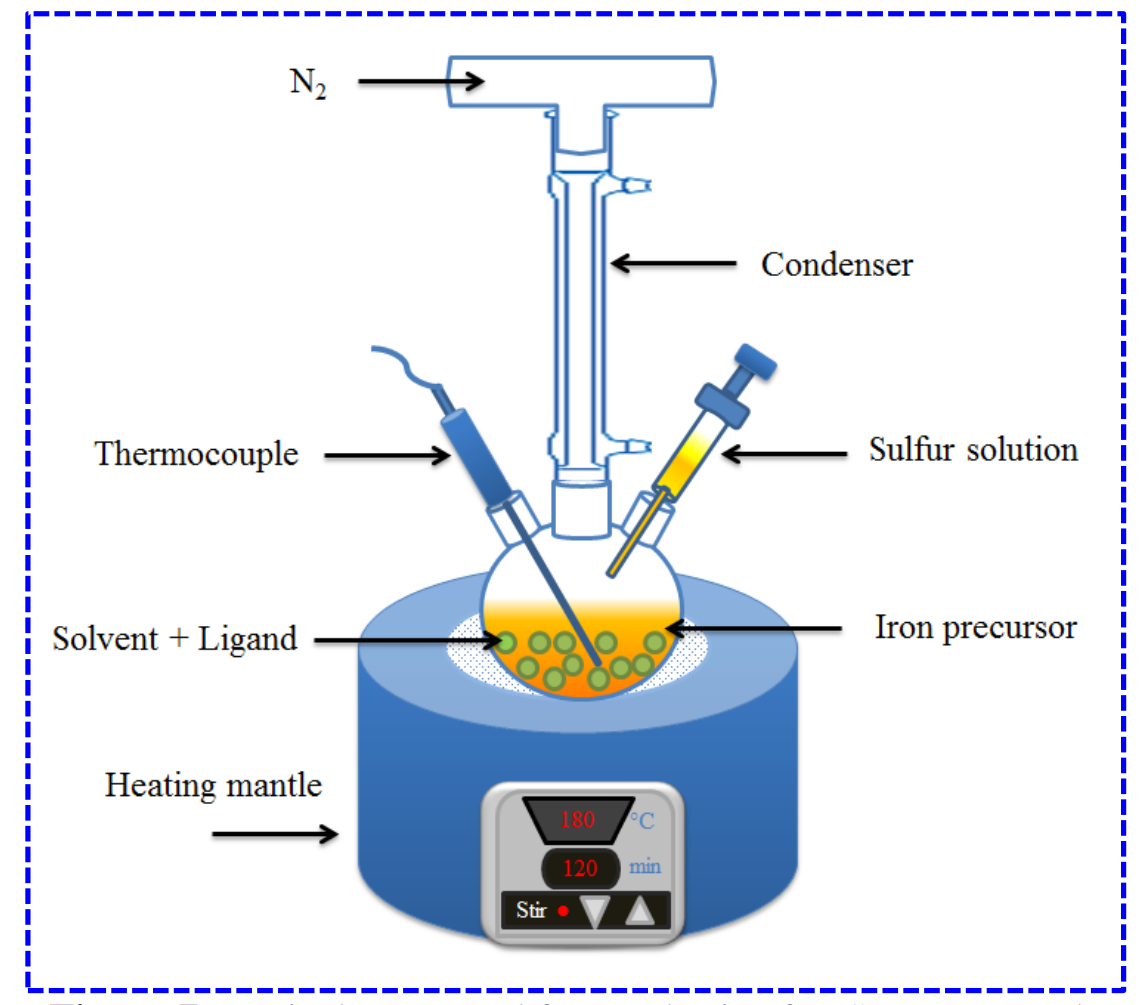

Figure 7. Typical HIM used for synthesis of $\mathrm{FeS}_{2}$ nanocrystals

HIM involves a quite cautious synthetic route via toxic precursors under inert atmosphere using standard Schlenk line techniques. Puthussery et al. ${ }^{[134]}$ prepared colloidal $\mathrm{FeS}_{2}$ nanocrystals by injecting sulfur solution dissolved in DPE (diphenyl ether) into a solution of $\mathrm{FeCl}_{2}$ in ODA (octadecylamine) at $220{ }^{\circ} \mathrm{C}$ for several hours stirring. The morphology of $\mathrm{FeS}_{2}$ nanocrystals varies from oblate and spheroidal single crystals (diameters $=5-20 \mathrm{~nm}$ ) to doughnut like appearance, with depressions or holes in their centres. At slow growth rate i.e., at a low precursor concentration, pyrite nanocubes (125-250 $\mathrm{nm}$ in 20-180 min) were obtained 


\section{WILEY-VCH}

due to low nuclei concentration and slow growth (diffusion limited) in quasi-equilibrium. The anisotropic structures nanodendrites were obtained at a high precursor concentration due to high nuclei concentration and consequently the nuclei grew fast. The growth mechanism is kinetically controlled (oriented attachment) to minimize the overall free energy of the system. ${ }^{[135]}$

Wang et al. ${ }^{[164]}$ theoretically investigated that the geometrical shape of a crystal depended on the ratio $(\mathrm{R})$ of the growth rate along the [100] directions to that along the [111] directions depending on the facet surface energy. Gong et al. ${ }^{[145]}$ suggested kinetically oriented attachment growth model for $\mathrm{FeS}_{2}$ nanoclusters in two different paths A and B. Path A leads to cubic $\mathrm{FeS}_{2}$ nanocrystals with $\{100\}$ surface planes at low injection temperatures while path $\mathrm{B}$ towards $\mathrm{FeS}_{2}$ nanosheet formation $\{110\}$ surface facets at higher temperature of injection. The size of $\mathrm{FeS}_{2}$ cubic nanocrystals will be controlled by heating rate and reaction time in the coalescence state and collision state. Theoretical shape-dependent thermodynamic model for the morphological stability of pyrite nanocrystals was proposed by Barnard et $a l .{ }^{[165]}$ According to this model, the nano-morphology of pyrite nanocrystals $(35 \mathrm{~nm})$ is not associated to temperature but affected by the local chemical environment.

Pyritohedron (Twelve sided polyhedron) nanocrystals, featuring crystallographic orientation of surface facets $\{210\}$, under ambient conditions (at ambient temperatures) is energetically favourable in Fe-rich environment, whereas octahedral shapes featuring crystallographic orientation of surface facets $\{111\}$ are favoured under S-rich conditions. Thermodynamically shape controlled model for synthesis of $\mathrm{FeS}_{2}$ nanocrystals is based on Lewis acid-base concept. ${ }^{[166]}$ Morphology of the $\mathrm{FeS}_{2}$ nanocrystals depends on the reaction temperature and concentration and nature of chemical precursors. Injection of sulphur at low temperatures and low concentration of the iron monomers yields cubic nanoparticles growth 


\section{WILEY-VCH}

through low surface energy facet [100] while at high temperatures growth will proceed through high surface energy facet [111] resulting nanosheet formation. $\mathrm{FeS}_{2}$ nanocrystals (NCs) synthesized via a colloidal hot injection route in an excess sulfur environment by using solutions of $\mathrm{FeCl}_{2} \cdot 4 \mathrm{H}_{2} \mathrm{O}(100 \mathrm{mg})$ and $\mathrm{ODA}(10 \mathrm{~g})$ in $40 \mathrm{~mL}$ of paraffin liquid $\left(220^{\circ} \mathrm{C}\right.$ for 1 h) and $\mathrm{S}(96 \mathrm{mg})$ in $5 \mathrm{~mL}$ of DPE $\left(5 \mathrm{ml} ; 150{ }^{\circ} \mathrm{C}\right.$ for $\left.1 \mathrm{~h}\right)$ at reaction temperature $205^{\circ} \mathrm{C}$. The metallic $\mathrm{FeS}$ and $\mathrm{Fe}_{3} \mathrm{~S}_{4}$ phases act as intermediate phases to form a semiconducting $\mathrm{FeS}_{2}$ phase and can be removed efficiently by controlling the growth time and adding excess sulfur. The sulfur to iron ratio changed from 1.1 to 2.1 as the iron sulfide transformed from FeS to hexagonal nano-sheets of $\mathrm{Fe}_{3} \mathrm{~S}_{4}$ and lastly to cubic $\mathrm{FeS}_{2} \cdot{ }^{[167]}$ Recently, $\mathrm{FeS}_{2}$ nanocrystals (average edge length $=37 \pm 11 \mathrm{~nm})$ and $\mathrm{FeS}_{2}$ cubes $(88 \pm 14 \mathrm{~nm})$ synthesised in oleylamine (OLA) with sulfur to iron ratio 6. The higher sulfur concentration favours higher $\mathrm{FeS}_{2}$ formation rate that is the rate-determining step. ${ }^{[168]}$ A very recent investigation of growth mechanism of $\mathrm{FeS}_{2} \mathrm{NCs}$ by Zhu et al. ${ }^{[169]}$ revealed that OLA in replacement with ODA as a solvent leads to the growth of anisotropic pyrite NCs with more branches, chromosome-like shapes along the $\langle 210\rangle$ direction.

Pure $\mathrm{FeS}_{2}$ nanocrystals (mean size: cubic $(80 \mathrm{~nm})$ and spherical $\left.(30 \mathrm{~nm})\right)$ were synthesised using tri-octylamine (TOA) and OLA as the solvents. The cube and spherical $\mathrm{FeS}_{2}$ nanocrystals exhibited indirect bandgap of $0.95 \mathrm{eV} \& 1.0 \mathrm{eV}$ and direct band gap of 1.5 $\mathrm{eV} \& 3.2 \mathrm{eV}$ respectively. ${ }^{[170]}$

\subsection{Hydrothermal (HTM) or Solvothermal Method (STM)}

The most common and scalable method for synthesis of $\mathrm{FeS}_{2}$ nanocrystals is hydrothermal/solvothermal method. Hydrothermal is an exceptional method for synthesis of nanocrystalline inorganic materials. ${ }^{[171]}$ Water as solvent plays a key role for the phase transformation of the materials at particular temperature and pressure in a closed vessel 


\section{WILEY-VCH}

typically called autoclave (Figure 8). If the reaction medium of the autoclave is replaced by a solvent other than water the same method is called solvothermal method. Solvents can be brought to temperatures well above their boiling points by the increase in autogenous pressures resulting from heating. ${ }^{[172]}$ By designing chemical reactions, selecting suitable solvents, controlling the reaction conditions (surfactants/ligands), different morphologies of $\mathrm{FeS}_{2}$ nanocrystals can be prepared.

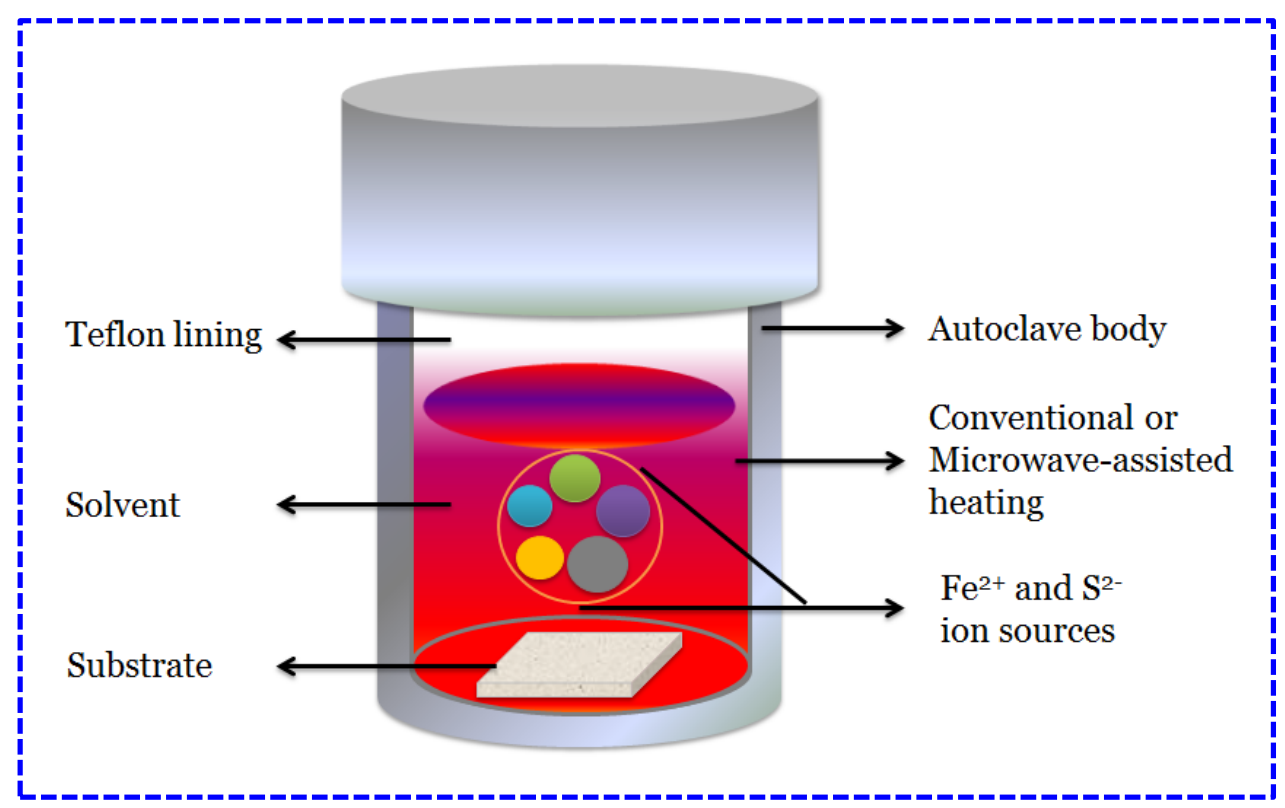

Figure 8. Typical HTM/STM used for synthesis of $\mathrm{FeS}_{2}$

In the solution-phase synthesis process like hydrothermal/solvothermal, capping agents/surfactants reduce particle aggregation by "selective adhesion (electrostatic and steric effect)'. They can bond to primary nanoparticles surface via physical and chemical bonding and selectively adsorb on specific facets of crystals to modify the crystal growth accordingly. The presence of capping agents/surfactants also strengthens the particle's anti-oxidized ability. Structures, solubility, charge and polarity of surfactants influence crystal growth through different faces. Ultimately, morphology of pyrite nanostructures can be modified by employing various surfactants e.g., TX-100 (triton X-100), PVP (poly(vinylpyrrolidone)), 


\section{WILEY-VCH}

CTAB (cetyltrimethylammonium bromide), dodecanethiol (DDE), sodium lauryl benzenesulfate (SBS), sodium dodecyl sulphate (SDS) or/and poly (ethylene glycol) (PEG).

The most common surfactant PVP is extensively used to obtain pure phase pyrite. It is a crystal growth modifier under hydrothermal/ solvothermal conditions. ${ }^{[173]}$ Wang et el. ${ }^{[133]}$ reported a simple surfactant-assisted ethylene glycol-mediated solvothermal method for the synthesis of $\mathrm{FeS}_{2}$ crystallites using different surfactants including PVP. When PEG was used as the additive, products consist of microspheres composed of sheets and sphere-like particles with broad size distribution. When CTAB and SBS were used as the additives, the products were all irregular particles. The strong interaction between PVP and the $\{111\}$ faces gives the octahedral shape while in presence of TX-100, [111] direction will grow fast due to its larger $\mathrm{Fe}^{2+}$ density. Ethylenediamine (EDA) and PVP act as reducing agent for the synthesis of hierarchical pyrite microparticles. The bonding of PVP on $\{111\}$ facets leads to the aggregation of cubic-like hierarchical pyrite microparticles. ${ }^{[174]}$

There is an optimum amount of capping agent/surfactant that can reduce particle size to minimum extent. Xia et al. ${ }^{[175]}$ reported the facile hydrothermal process for $\mathrm{FeS}_{2}$ nanocrystals. A reaction was carried out in $25 \mathrm{~mL}$ Teflon-lined autoclave containing $\mathrm{Fe}(\mathrm{acac})_{3}: 0.353 \mathrm{~g}$ or nano- $\mathrm{Fe}_{3} \mathrm{O}_{4}: 0.231 \mathrm{~g}, \mathrm{Na}_{2} \mathrm{~S}_{2} \mathrm{O}_{3} .5 \mathrm{H}_{2} \mathrm{O}: 0.496 \mathrm{~g}$ and sulfur powder: 0.16 $\mathrm{g}$ in $12 \mathrm{~mL}\left(0.1 \mathrm{~mol} \mathrm{~L}^{-1} ; \mathrm{pH}=3\right)$ sodium tartrate-tartaric acid buffer solution and 1octylamine $(4 \mathrm{~mL})$ and ethanol $(4 \mathrm{~mL})$ at $220{ }^{\circ} \mathrm{C}$ for $12 \mathrm{~h}$. The effect of iron source was significantly observed in $\mathrm{FeS}_{2}$ nanocrystals (diameter $=10-35 \mathrm{~nm}$ from nano- $\mathrm{Fe}_{3} \mathrm{O}_{4}$ and $10-$ $30 \mathrm{~nm}$ from $\left.\mathrm{Fe}(\mathrm{acac})_{3}\right)$. Also micro-particles of size $500 \mathrm{~nm}$ were obtained without capping agent/surfactant (1-octylamine). When amount of 1-octylamine was increased from $1 \mathrm{ml}$ to 4 $\mathrm{ml}$, the particle size decreased from $200 \mathrm{~nm}$ to $20 \mathrm{~nm}$. Further increment of 1-octylamine up 


\section{WILEY-VCH}

to $8 \mathrm{ml}$ did not affect the particle size significantly. Nanoparticles revealed higher charge capacity, a more stable discharge plateau and better cycling performance.

Additionally, surfactant has several advantages like phase purity and crystallinity of iron pyrite nanostructures by increasing viscosity of the reaction system. Consequently, species other than pyrite such as marcasite were retained at a much lower concentration even at low $\mathrm{pH}$ of the reaction system. Irregular crystal growth through oriented-attachment mechanism would also be avoided by minimizing the total energy of the system. The secondary nucleation and growth of $\mathrm{FeS}_{2}$ nanocrystals in solution through Ostwald ripening yields large uniform monodisperse microspheres in a microwave-assisted polyol method. ${ }^{[137]}$ Certainly, the NCs size could be easily tuned over a low nano size range in short times with high degree of monodispersity depending on the surfactant, temperature and microwave (MW) power. ${ }^{[176]}$ Recently, Wu et al. ${ }^{[177]}$ synthesised FeS $_{2}$ microspheres $(\sim 1.1 \mu \mathrm{m})$ via a facile microwave-assisted solvothermal method at $200{ }^{\circ} \mathrm{C}$ for $1.5 \mathrm{~h}$ using anhydrous $\mathrm{FeCl}_{3}(2$ mmol) and PVP (0.6 g) dissolved in EG (30 mL), $\mathrm{Na}_{2} \mathrm{~S}(2 \mathrm{mmol})$ and sulphur powder (4 mmol). Relatively long reaction time yielded uniform $\mathrm{FeS}_{2}$ microspheres with smooth surfaces. Consequently, microwave assisted method is a favourable growth method for the synthesis of phase pure and homogeneous $\mathrm{FeS}_{2}$ nanostructures.

Dimethylformamide (DMF) and ethylene glycol (EG) mixed solvents yields highly stable nanoflakes-built pyrite $\mathrm{FeS}_{2}$ microspheres under solvothermal conditions in absence of surfactant with and without using urea $\mathrm{CO}\left(\mathrm{NH}_{2}\right)_{2} \cdot{ }^{[156]}$ It has a tremendous impact on the particle size distribution while phase purity was noticed to be autonomous. Hydrolysis of urea provides a trigger to speed up the reaction among the EG (reducing agent), S (sulfur source), and $\mathrm{Fe}^{3+}$ (iron source). Together the concentration of the solvents and urea influence the morphology of the product. ${ }^{[136]}$ CTAB or Triton X-100 assisted synthesis of monodispersed 


\section{WILEY-VCH}

air stable hierarchical $\mathrm{FeS}_{2}$ particles with 3D flower like morphology under hydrothermal/ solvothermal conditions was achieved by Kush et al. ${ }^{[178]}$ In a typical growth mechanism, weak protecting/coordinating agent SDS facilitated the agglomeration of $\mathrm{FeS}_{2}$ nanoparticles to form the $\mathrm{FeS}_{2}$ nanosheets. These metastable $\mathrm{FeS}_{2}$ nanosheets then oriented to form hierarchical flower like particles in $\langle 111\rangle$ direction by oriented attachment (OA) mechanism. ${ }^{[178]}$ The polymorph of pyrite, marcasite phase lies at the lowest-energy phase region in acidic media at small particle sizes (Figure 9). The nucleation kinetics influences the system at this stage of growth that is within the scope of classical nucleation theory. The phase selection in pyrite-marcasite system can be elucidated by the surface stability of the pyrite-marcasite phases as a function of ambient $\mathrm{pH}$ within nano-size regimes relevant to nucleation under hydrothermal conditions. ${ }^{[179]}$

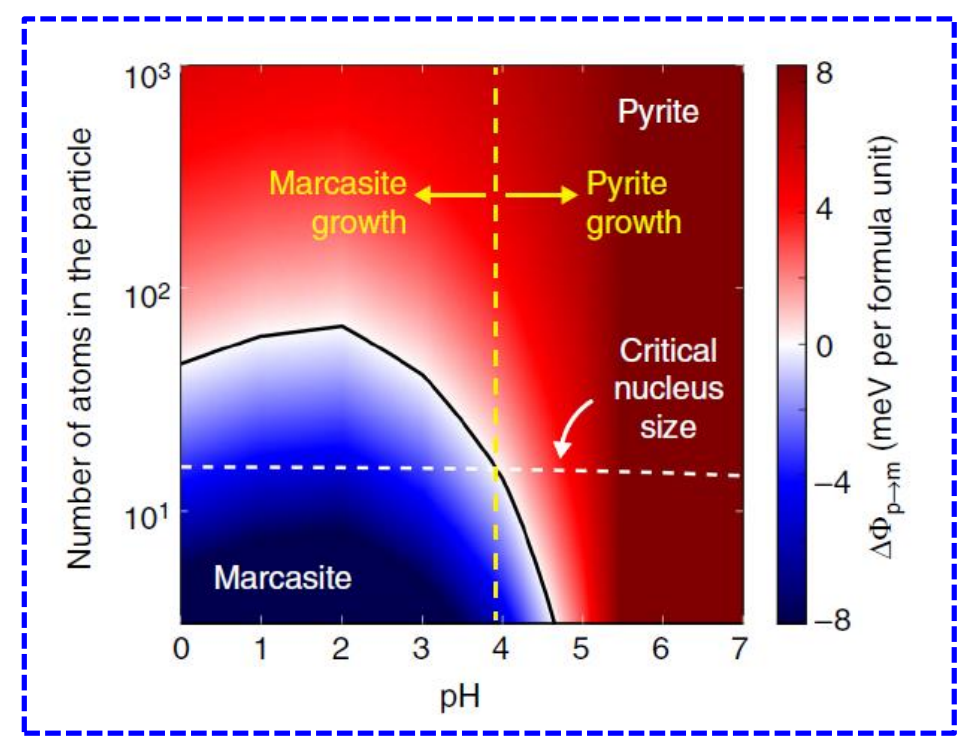

Figure 9. Thermodynamics of nanoscale $\mathrm{FeS}_{2}$. The finite-size phase diagram of $\mathrm{FeS}_{2}$ across a range of $\mathrm{pH}$ values, illustrating the low-particle size, low-pH region of thermodynamic stability for marcasite. Note that we report a single critical nucleus size based on the experimentally reported supersaturation ${ }^{[180]}$ for both pyrite and marcasite because the difference between the two is negligible. ${ }^{[179]}$ Reproduced with permission from ref. ${ }^{[179]}$. Copyright 2016 Nature Publishing Group.

The monodisperse, colloidal, spherical, and phase-pure $\mathrm{FeS}_{2} \mathrm{NCs}$ with the size of $5.5 \pm 0.3$ $\mathrm{nm}$ in diameter were synthesised using single source precursor iron diethyldithiocarbamate 


\section{WILEY-VCH}

via post digestive ripening process by Yoder et al. ${ }^{[152]}$ They proposed mechanism of two acidcatalysed steps for decomposition of the ligand that provides quantum mechanically based insight into the reaction for both hydrothermal and solvothermal reactions (Figure 10). Protonation can occur either on the carbon atom or one of the complexed sulfur atoms in the dithiocarbamate moiety $\left(-\mathrm{S}_{2} \mathrm{CNEt}_{2}\right)$.

(i) Carbon protonation that involves the weakening of both $\mathrm{C}-\mathrm{S}$ bonds by the decrease in charge density (Figure 4B).

(ii) A nucleophile $\left(\mathrm{HO}^{-}\right.$or $\left.\mathrm{HS}^{-}\right)$attacks the previously protonated carbamate carbon (the electrophilic centre causing cleavage of the $\mathrm{C}^{-} \mathrm{S}^{\prime}$ bond (Figure 4C). Following, protonation at a sulfur site $\left(\mathrm{S}^{\prime \prime}\right)$ results in degradation of the $\mathrm{Fe}-\mathrm{S}^{\prime \prime}$ bond, liberating the ligand and producing an $\mathrm{FeE}_{2} \mathrm{~S}^{\prime}$ intermediate state (Figure 4D). Followed by dimerization (Figure 4E), two liberated sulfur atoms are bridged between monomers to form an $\mathrm{S}-\mathrm{S}$ bond, i.e., the oxidation of $\mathrm{S}^{2-}$ to $\mathrm{S}_{2}{ }^{2-}$. It is believed that the protonation, nucleophilic attack, and dimerization would occur at other ligand sites and lead to the ultimate formation of $\mathrm{FeS}_{2}$ seeds and NCs. 


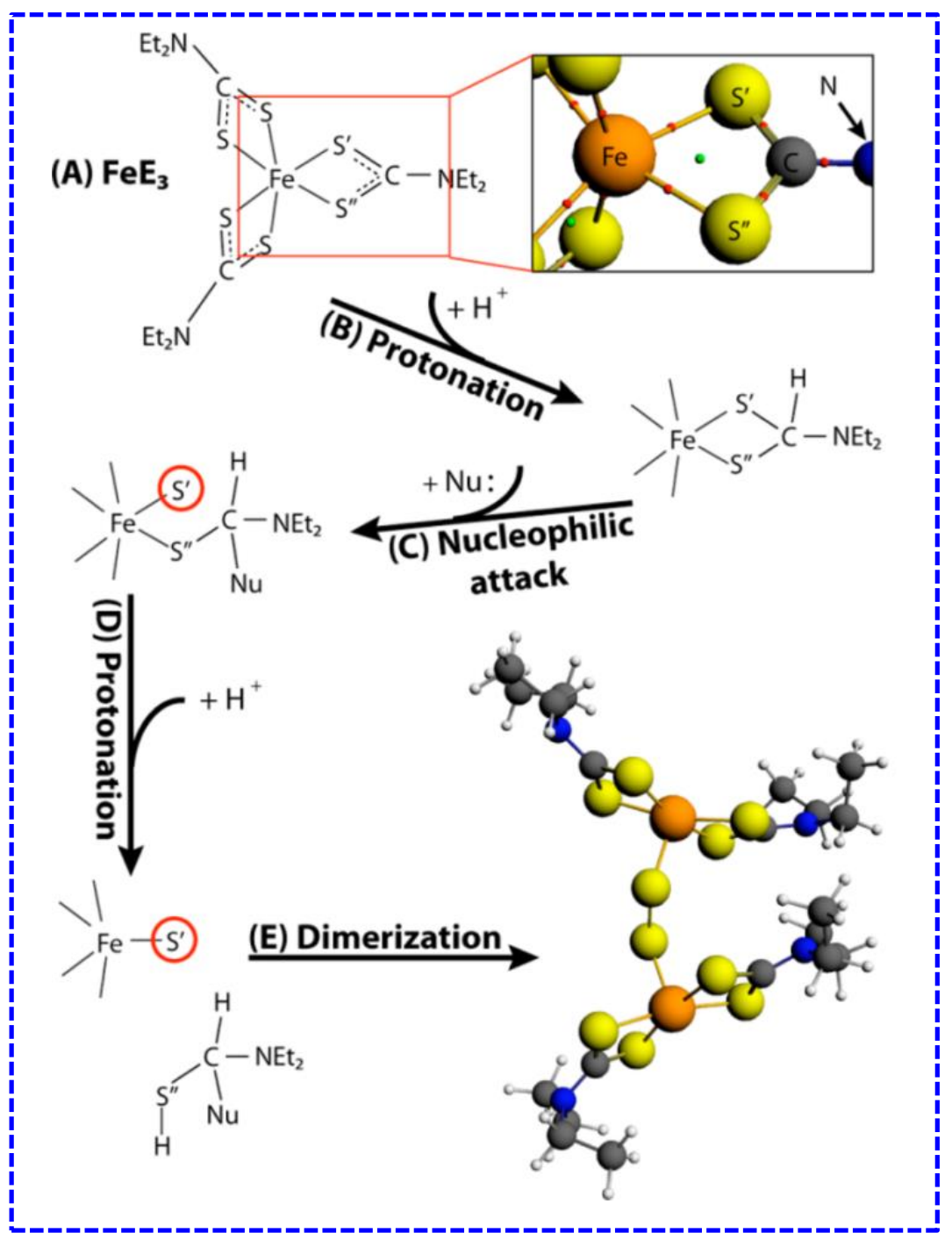

Figure 10. Reaction mechanism for the first step of $\mathrm{FeS}_{2}$ formation, proposed by the DFT computation. (A) The left side is the structure of the $\mathrm{FeE}_{3}$ precursor; the right side is a balland-stick rendering of the highlighted region shown on the left. The red spheres correspond to bond $\mathrm{CPs}$, and the green sphere represents the ring $\mathrm{CP}$ for $\mathrm{Fe}-\mathrm{S}-\mathrm{C}-\mathrm{S}-\mathrm{Fe}$. (B) Protonation of the central carbon. (C) Nucleophilic attack of the central carbon by HO- or HS-. (D) Protonation of one of the sulfur atoms in one E moiety. (E) Dimerization through bridging the free sulfurs (circled in red). ${ }^{[152]}$ Reproduced with permission from ref. ${ }^{[152]}$. Copyright 2014 American Chemical Society.

\subsection{Effect of ligands/surfactants/capping agents}

Ligands play an important role in controlling the growth (crystal structure, shape, shape distribution, and stability) of colloidal inorganic nanocrystals. Organic surfactants modify nanocrystal's shape kinetically through selective adhesion during growth. Exchange of ligands through organic surfactants ensures chemical functionalities of the physical 


\section{WILEY-VCH}

nanocrystal properties. The chemical nature and physical dimension of the ligands may influence the monomers and nanocrystals simultaneously in the growth stage. Consequently, the properties of the monomers are influential during the formation of high-quality semiconductor nanocrystals in non-coordinating solvents. Concentration and chain length of the ligand regulate the monomer reactivity (bonding strength of the anchoring group and the steric effects) in non-coordinating solvents. Hence a balance between nucleation and growth takes place that is the key for the control of size and size distribution during the synthesis of nearly monodisperse dot-shaped colloidal nanocrystals. ${ }^{[181,182]}$

\subsubsection{Morphology Control}

The morphological control of nano-colloids of $\mathrm{FeS}_{2}$ arises due to the variances in reaction conditions, crystal growth rates along different crystalline directions and selective adsorption of solvents on different crystal phases of $\mathrm{FeS}_{2}$. Selective adsorption of these polar solvents on different crystal phases of $\mathrm{FeS}_{2}$ and related modification of crystal growth rates along different crystalline plane directions may also influence the route of self-assembly of NPs into NWs, NRs, and NSs. Subsequent assembly process based on hyposulfite $\left(\mathrm{S}_{2} \mathrm{O}_{3}{ }^{2-}\right)$ selfdecomposition route transfigure metastable $\mathrm{FeS}_{2} \mathrm{O}_{3}$ nanoflats into pyrite nanowebs (densities of nanowires up to $10^{10} \mathrm{~cm}^{-2}$ ) containing interlinked nanowires (ca. diameters $40 \mathrm{~nm}$ ) in benzene as solvent without using capping agents. Benzene acts as the most complimentary solvent for the pyrite nanoweb growth, which may be related to its nonpolar nature and good thermal stability. 2D nanowebs could not be obtained when reaction media (benzene $\left(\mathrm{C}_{6} \mathrm{H}_{6}\right)$ ) interchanged with distilled water, anhydrous alcohol or carbon disulphide $\left(\mathrm{CS}_{2}\right)$; reaction temperature or reaction chemicals (sodium thiosulfate $\left(\mathrm{Na}_{2} \mathrm{~S}_{2} \mathrm{O}_{3}\right)$ ) replacement with sodium sulphide $\left(\mathrm{Na}_{2} \mathrm{~S}\right)$, sodium sulphate $\left(\mathrm{Na}_{2} \mathrm{SO}_{4}\right)$ or sodium sulfite $\left(\mathrm{Na}_{2} \mathrm{SO}_{3}\right){ }^{[130]}$ 


\section{WILEY-VCH}

Barnard et al.'s systematic modelling suggests that the morphology of pyrite nanorods is more likely to be a function of surface ligands such as EDA. ${ }^{[183]}$ Polar solvents thioglycolic acid (TGA) concentration, and EDA as a co-solvent may also affect the size controlled growth of nanoparticles (2-5 nm), nanowires (80-120 $\mathrm{nm}$ and length exceeding $5 \mu \mathrm{m})$, nanorods, and nanosheets (100-200 nm lateral dimensions and $2 \mathrm{~nm}$ thickness) ${ }^{\left[{ }^{[9]}\right.}$ The use of EDA during synthesis may be responsible for the rapid growth along \pm [111] direction, rather than the more favourable $\pm[001]$ or $\pm[011]$ directions. ${ }^{[184]}$

Carbamates, carboxylic acids, xanthates, trithiocarbonates, primary and secondary amines, and primary thiols, phenyl diamines and high-molecular weight surfactants such as PVP and TX-100 have been utilized for pyrite nanocrystals synthesis. But OLA, DDE, and TOPO are commonly used capping ligands for shape and size controlled synthesis of pyrite nanocrystals. Inter-ligand interactions influence monomer reactivity during growth of pyrite NCs. Rapid nucleation of the monomers results in large size of pyrite particles. This can be only prevented by slowing dissolution of iron monosulfides in reaction controlled conditions. Inter-ligand interaction of HDA is strong than ODA that eliminates the slow dissolution of FeS but creating irregular small particles. For controlled size and shape OLA addition limits step to pyrite nanocubes $(\sim 37 \mathrm{~nm})$ growth. ${ }^{[139]}$ An infrequent ligand, 1-hexadecanesulfonate in OLA leads to pyrite cubic nanocrystals $(80 \mathrm{~nm}) .{ }^{[143]}$ On the other hand, TOPO as a surfactant in octylamine (OCA) as a coordinating solvent caused the formation of phase pure iron pyrite nanocrystals $(70-250 \mathrm{~nm})$. Since TOPO is a stronger base than OCA and binds well with Fe, however, the phosphorous in TOPO may bind and coordinate well with sulfur, owing to its obvious attractive affinity making nanoparticle surface passivated, robust, and stable. ${ }^{[185]}$ The cubic FeS 2 nanocrystals $(70-150 \mathrm{~nm})$ were recently synthesized by HIM using 


\section{WILEY-VCH}

iron(II) bromide $\left(\mathrm{FeBr}_{2}\right)$ as a new iron precursor, elemental sulfur as the sulfur source, TOPO and diol as capping ligands, and OLA as a non-coordinating solvent during the synthesis. ${ }^{[158]}$ OCA (as coordinating agent and surfactant) yielded phase pure iron pyrite nanocrystals $(\sim 20$ $\mathrm{nm})$ without any impurity of marcasite, pyrrhotite or greigite. ${ }^{[186]}$

An unbranched polymer like PVP is also a good capping agent. PVP molecules entangle nanoparticles with partial functional group. They stick to the surface and cover it. A side group of five-membered ring and a polymer long chain of PVP structure with large steric hindrance prevent particle agglomeration. On the other hand, the oxygen atoms of PVP with two lone electron pairs strongly bind to certain crystal faces. The adsorption of iron ions to reduce the rate of chemical bond combination and effectually forms a stable dispersed system, favourable under these conditions. Consequently, PVP changes the relative growth rate of different crystal surfaces affecting the morphologies and sizes of pyrite e.g., nanopolyhedrons, nanocubes $(90-570 \mathrm{~nm})$, nanooctahedrons $(130-360 \mathrm{~nm})$ and irregular nanocrystals under different reaction conditions. ${ }^{[187]}$

\subsubsection{Size modification}

Pyrite rod like nanocrystals (diameter of $\sim 10 \mathrm{~nm}$ and a length of $\sim 20-30 \mathrm{~nm}$ ) were prepared in ODA and OLA. Quasi-cubic NC agglomerates $(\sim 200 \mathrm{~nm})$ were obtained when the reactant concentration was reduced or an additional capping agent, TOPO or diol was introduced in the reaction mixture. ${ }^{[188]}$ The indirect bandgap of rod like nanocrystals was 1.24 and $1.16 \mathrm{eV}$ for NC- ODA and NC-OLA respectively. The first and second direct transitions were 2.24 and $2.94 \mathrm{eV}$ for NC-ODA and 1.97 and $2.90 \mathrm{eV}$ for NC-OLA. The indirect bandgap of pyrite NCs observed to be larger than bulk pyrite. The size dependence of the bandgap of $\mathrm{FeS}_{2}$ nanocrystals was calculated using equation (1): ${ }^{[189]}$ 


$$
E_{g}^{N C}(R)=E_{g}^{b u l k}+\frac{h^{2} \pi^{2}}{2 R^{2}}\left[\frac{1}{m_{c}^{*}}+\frac{1}{m_{h}^{*}}\right]
$$

Where $E_{g}^{N C}=$ bulk bandgap; for pyrite $E_{g}^{N C}=0.95 \mathrm{eV}$

$R=$ radius of nanocrystals $(\mathrm{NC})$

$h=$ Plank's constant $=6.63 \times 10^{-34} \mathrm{Js}$

$m_{e}^{*}=$ effective electron mass; for pyrite $m_{e}^{*}=0.25 m_{e}$

$m_{h}^{*}=$ effective hole mass; for pyrite $m_{h}^{*}=2.2 m_{e}$

Values for pyrite are taken from literature. ${ }^{[190]}$

Bandgap modification was observed due to quantum confinement effect. Quantum confinement effect shifts the absorption edge to high energy values (blue shift) due to the reduced size of the $\mathrm{FeS}_{2}$ nanoparticles. ${ }^{[191]}$

\subsubsection{Stability enhancement}

The aging of nanomaterials under ambient conditions influence the performance of devices. Air stability of pyrite $\mathrm{NC}$ films is an important factor as its surface structure is not thermodynamically and morphologically stable. ${ }^{[192]}$ Density-functional theory (DFT) calculations for the adsorption and reactions of oxygen $\left(\mathrm{O}_{2}\right)$ and water $\left(\mathrm{H}_{2} \mathrm{O}\right)$ with the $(100)$ surface of pyrite leads to the complete oxidation of a surface sulfur to $\mathrm{SO}_{4}{ }^{2-}$ attributed to $\mathrm{O}^{2-}$ and $\mathrm{OH}^{-}$species that act as proton acceptors for water environment. The activation energies for the various steps are all in the range $20-25 \mathrm{kcal} / \mathrm{mol}$, proposing that oxidation is slow but still feasible at room temperature. ${ }^{[193]}$

Oxidation of pyrite NC thin films can be controllable using common photovoltaic ligands, capping agents and/ or passive coatings. Ligands provide a physical barrier between the NCs and the environment, thus making the nanocrystals less sensitive to environmental 


\section{WILEY-VCH}

fluctuations, surface chemistry and photo-oxidation. They provide an efficient passivation of the NC surface trap states by surrounding them as protective shell. Puthussery et al. ${ }^{[134]}$ pioneered the hot injection method for synthesis of pyrite NCs (diameters 5-20 nm). ODA observed to be an inappropriate ligand for preparing stable pyrite NCs inks. Partial ligand exchange with octadecyl xanthate $\left(\mathrm{C}_{18} \mathrm{H}_{37} \mathrm{OCS}_{2}{ }^{-}\right)$provides stable colloidal dispersions in chloroform for at least 9 months when stored in a nitrogen-filled glove box. While chloroform solutions of amine/ammonium-capped NCs without xanthate showed complete decomposition within weeks of storage in air in the dark, leaving a yellow precipitate and clear supernatant. ${ }^{[134]}$ TOPO forms stable surface structures by passivating both Fe and $\mathrm{S}$ sites on $\mathrm{FeS}_{2}$ NC surface. ${ }^{[194]}$

Nanocubes $(\sim 150 \mathrm{~nm}$; 1-octylamine: $6.0 \mathrm{~mL}$ and 1-octanol: $6.0 \mathrm{~mL}$; reaction time: 1 h), spheroidal NCs ( 50 nm; 1-octylamine: $12.0 \mathrm{~mL})$ and microspheres ( 3 $\mu \mathrm{m}$; 1-octanol $(12.0 \mathrm{~mL}))$ consisting of nanoparticles were prepared via oriented attachment via STM in 25 ml Para polyphenol-lined stainless steel autoclave at $260{ }^{\circ} \mathrm{C}$ (Figure 11). This work concluded that 1-octanol plays a key role in air-stability of $\mathrm{FeS}_{2}$ nanocubes prepared in pure 1-octylamine. ${ }^{[195]}$ 


\section{WILEY-VCH}
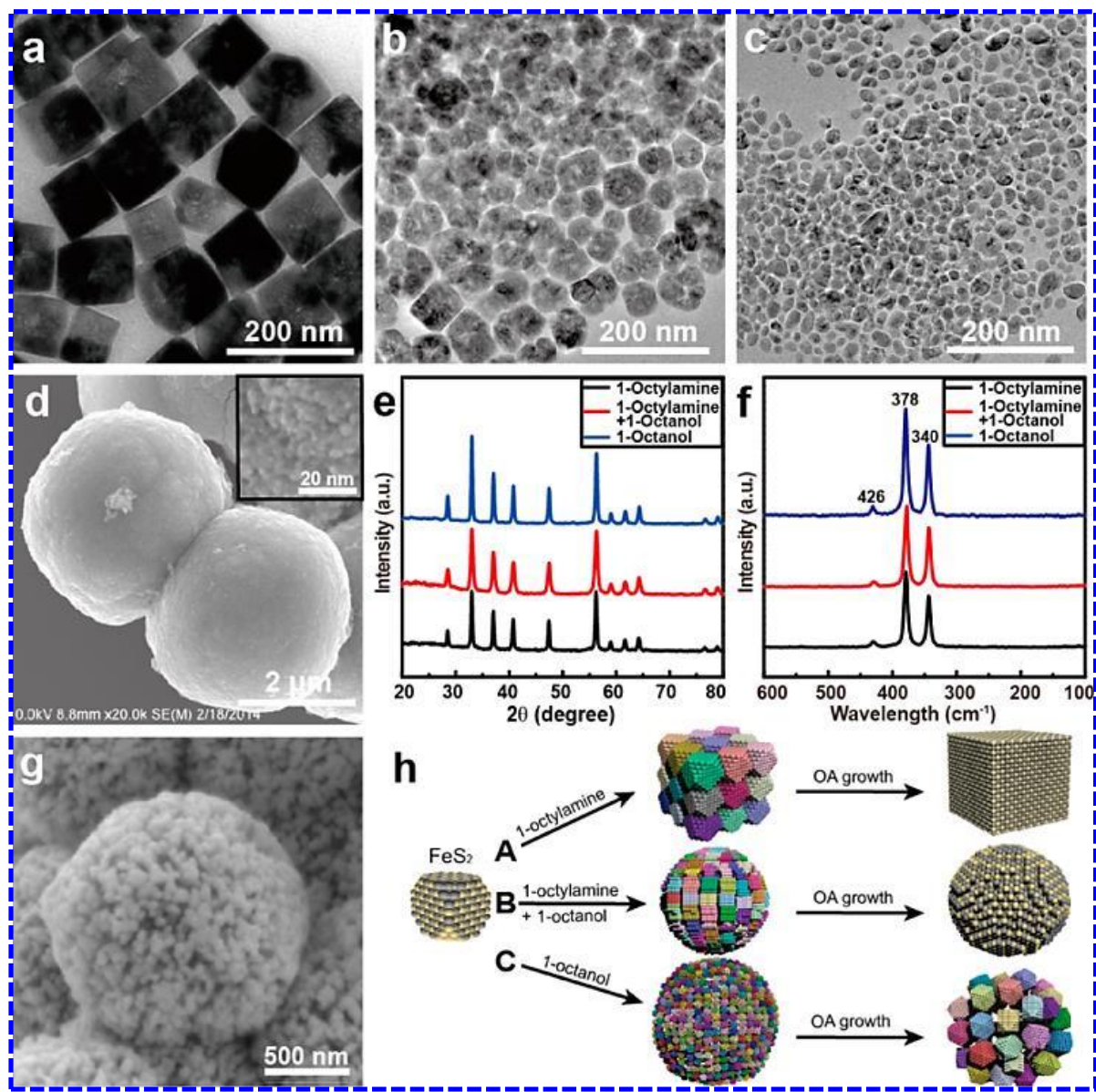

Figure 11. TEM images of $\mathrm{FeS}_{2}$ products prepared with solvents of 1-octylamine and 1-octanol in different volume ratios: (a) 12:0, (b) 8:4, and (c) 6:6. SEM images of the pyrite $\mathrm{FeS}_{2}$ microspheres prepared in pure 1-octanol after reaction for (d) $5 \mathrm{~h}$ and (g) $36 \mathrm{~h}$. (e) XRD patterns and (f) Raman spectra of $\mathrm{FeS}_{2}$ products prepared in different solvents. (h) Schematic illustration of the formation of $\mathrm{FeS}_{2}$ nanocubes, spheroidal $\mathrm{NCs}$, and microspheres (not in scale) ${ }^{[195]}$ Reproduced with permission from ref. ${ }^{195]}$. Copyright 2015 American Chemical Society.

\subsubsection{Surface functionalization}

Ligands not only influence morphology of the pyrite nano structures but also play a vital role in modification of optical and electronic properties of pyrite nanocrystal thin films by surface manipulation. Surface functionalization of pyrite nanocrystal thin films by various ligand groups implies optical shift and high conductivity by means of dielectric environment modification. The ionic liquids (Ethanedithiol (EDT), 1-hexyl-3-methylimidazolium bromide ([Hmim][Br]) and 1-butyl-3-methylimidazolium iodide (BMII)) enhance charge transport by 


\section{WILEY-VCH}

passivating the surface states of $\mathrm{FeS}_{2}$ nanomaterials (nanospheres (13.4 nm diameter) and nanocubes (47.5 nm side length) for better photocapacitors. ${ }^{[63]}$ Pyrite nanocrystals films (200 $\mathrm{nm}$ thickness) were functionalized with OLA as initial ligand and then ligand exchanged with five different ligand groups e.g., amines: ethylenediamine $\left(\mathrm{C}_{2} \mathrm{H}_{8} \mathrm{~N}_{2}\right)$, octylamine $\left(\mathrm{C}_{8} \mathrm{H}_{19} \mathrm{~N}\right)$ and dodecylamine $\left(\mathrm{C}_{12} \mathrm{H}_{27} \mathrm{~N}\right)$; thiols : ethanedithiol $\left(\mathrm{C}_{2} \mathrm{H}_{4}(\mathrm{SH})_{2}\right)$, benzenedithiol $\left(\mathrm{C}_{6} \mathrm{H}_{4}(\mathrm{SH})_{2}\right)$, 1,8-octanedithiol $\left(\mathrm{C}_{8} \mathrm{H}_{16}(\mathrm{SH})_{2}\right)$; organic acids: acetic acid $\left(\mathrm{CH}_{3} \mathrm{COOH}\right)$ and decanoic acid $\left(\mathrm{C}_{9} \mathrm{H}_{19} \mathrm{COOH}\right)$; pyridine $\left(\mathrm{C}_{5} \mathrm{H}_{5} \mathrm{~N}\right)$ and ammonium sulfide $\left(\left(\mathrm{NH}_{4}\right)_{2} \mathrm{~S}\right)$. The optical and electronic properties of $\mathrm{FeS}_{2}$ thin films were modified in terms of conductance as a function of shift in the optical absorption edge. The optical absorption edge of $\mathrm{FeS}_{2}$ nanocrystals shifted due to their polarizability and dielectric environment induced by different anchors. The anchor and bridging group together modified the conductivity and photoconductivity. Ammonium sulfide showed the largest red shift $(\sim 100 \mathrm{meV})$ and highest conductivity among different ligand groups as it provides a very short, inorganic linkage between $\mathrm{FeS}_{2}$ nanocrystals. Thiols reduced charge carrier trapping by effective passivation for sulfur vacancies on the pyrite nanocrystal surfaces. ${ }^{[196]}$

Similarly, Zhai et al. reported shift in energy level of $190 \mathrm{meV}$ in ligand capped $\mathrm{FeS}_{2}$ nanocrystals. They worked on ODA, 1,2-ethanedithiol, tetra-n-butylammonium iodide (TBAI), 3-mercaptopropionic acid (MPA), and diphenyl ether iodide and 1,2-ethanedithiol (EDT). The energy levels shifts of functionalized $\mathrm{FeS}_{2} \mathrm{NCs}$ were explained by the combined effect of two dipoles (the induced dipole at the ligand/NC interface and the ligand intrinsic dipole). TBAI and EDT capped $\mathrm{FeS}_{2} \mathrm{NCs}$ displayed the highest band edge energy shift and conductivity, respectively. FTO/capped-FeS $2 / \mathrm{Au}$ devices exhibited the conductivities three orders of magnitude under illumination. The conductivity of $\mathrm{FeS}_{2} \mathrm{NCs}$ films depend on ligand 


\section{WILEY-VCH}

molecular structures, interfaces between ligand and $\mathrm{NCs}$ and morphologies of film. $\mathrm{FeS}_{2} \mathrm{NCs}$ films also showed the less surface defect states. ${ }^{[197]}$

The surface of $\mathrm{FeS}_{2}$ nanocrystals were modified by ligand exchange from hexane $\left(\mathrm{C}_{6} \mathrm{H}_{14}\right)$ to polar formamide $\left(\mathrm{CH}_{3} \mathrm{NO}\right) . \mathrm{FeS}_{2}$ nanocrystals displayed red shift of corresponding LSPRs frequency demonstrating reduction of free carrier concentration. The photoresponse of sandwich $\mathrm{FeS}_{2}$ structure $\mathrm{FTO} / \mathrm{FeS}_{2}$ thin film (thickness of $500 \mathrm{~nm}$ ) $/ \mathrm{FTO}$ was carried out in the dark and under light of AM $1.5 \mathrm{G}$ irradiation with $100 \mathrm{~mW} \mathrm{~cm}{ }^{-2}$ power. The photocurrent of FeS2 nanocubes is better than nanoclusters due to strong optical absorption as described above. Photocurrent (at $1000 \mathrm{mV}$ ) of nanoclusters (136.8 \%) and nanocubes $(125.7 \%)$ was improved after ligand exchange. Such type of $\mathrm{FeS}_{2}$ nanocrystals with tunable LSPRs and better photocurrent can be further applied in low-cost photovoltaic applications. ${ }^{[121]}$

The surface functionalization, passivation and modification by inter-particle electronic coupling of pyrite nanocrystals using ligands can be a value-added approach for highly efficient photovoltaic devices. It requires more elaborate theoretical and experimental research on the pyrite NCs growth methods, surface, structural and electronic modification of pyrite for enhancing the open circuit voltage applicable to high efficiency pyrite cells. Pyrite NCs are particularly attractive because of the viewpoint of fabricating inexpensive, large-area photovoltaic devices by roll-to-roll deposition of NC solar ink or paint on flexible substrates. Photovoltaics based on NC-structures from solution provide an excellent scalability at very low cost comparative to conventional single-crystal and thin film approaches.

\section{Pyrite thin films for photovoltaics}

Basic construction of a thin film photovoltaic (PV) cell (pn-junction) includes two layers of different semiconducting materials e.g., a window layer (n-type) and an absorber layer (ptype), active components and substrate that is passive component. Highly efficient PV cell 


\section{WILEY-VCH}

should have high quantum and collection efficiency of excited charge carriers. Theoretical data shows efficiency of a solar cell increases as the number of junctions in a solar cell. ${ }^{[198]}$

Behaviour of individual layers of a PV cell is a significant factor affecting its efficiency. Some parameters that are influenced by types and properties of the pyrite films are as follows:

- Structural and textural (crystal structure, lattice constant, microstructure etc.)

- Physical and mechanical (expansion coefficient, mechanical adhesion, mobility etc.)

- Chemical (chemical affinity and mobility, coordination of atoms with surface etc.)

- Electrical and optical (resistivity, conductivity, absorption coefficient etc.)

In thin film technology, substrate plays a vital role as it provides base as well as support to the active components of PV cell so it should be chemically inert, mechanically stable and thermally compatible with the deposited layers. Usually wide band gap materials such as metal oxides are used as substrates that are 80-90 \% transparent to the light also known as transparent conducting oxides (TCO). Window layer is the window or path of light to the absorber layer and no photocurrent generates here. The band gap of the window layer should be high as compared to the absorber layer to provide maximum optical throughput. Lattice mismatch at the interface of two layers (at junction) is an important issue for epitaxial layers. The substrate also plays substantial role for enhancement of thin film electrical and optical properties.

Pyrite thin films have been synthesized by both physical and chemical methods (Table 3). Pyrite thin films have been fabricated directly (single step growth) by evaporating pyrite $\left(\mathrm{FeS}_{2}\right)$ or sulfur $(\mathrm{S})$ and iron $(\mathrm{Fe})$ as targets under vacuum. Secondly common method is two step growth of pyrite by sulfuration of pre-deposited thin films of iron $(\mathrm{Fe}),{ }^{[199]}$ iron(III) oxide or ferric oxide or hematite $\left(\mathrm{Fe}_{2} \mathrm{O}_{3}\right),{ }^{[200]}$ ferroferric oxide or magnetite $\left(\mathrm{Fe}_{3} \mathrm{O}_{4}\right),{ }^{[201,202]}$ iron sulfide or troilite $(\mathrm{FeS}),{ }^{[203]}$ or greigite $\left(\mathrm{Fe}_{3} \mathrm{~S}_{4}\right)^{[204]}$ (Figure 12). 


\section{WILEY-VCH}

Second most common experimental approach consists of two step fabrication of pyrite thin films via nanocrystals; (1) The synthesis of pyrite colloidal nanocrystals, (2) The deposition of pyrite thin films by drop casting, dip coating, spray or spin coating methods. Summary of these all methods is given in Table 3.

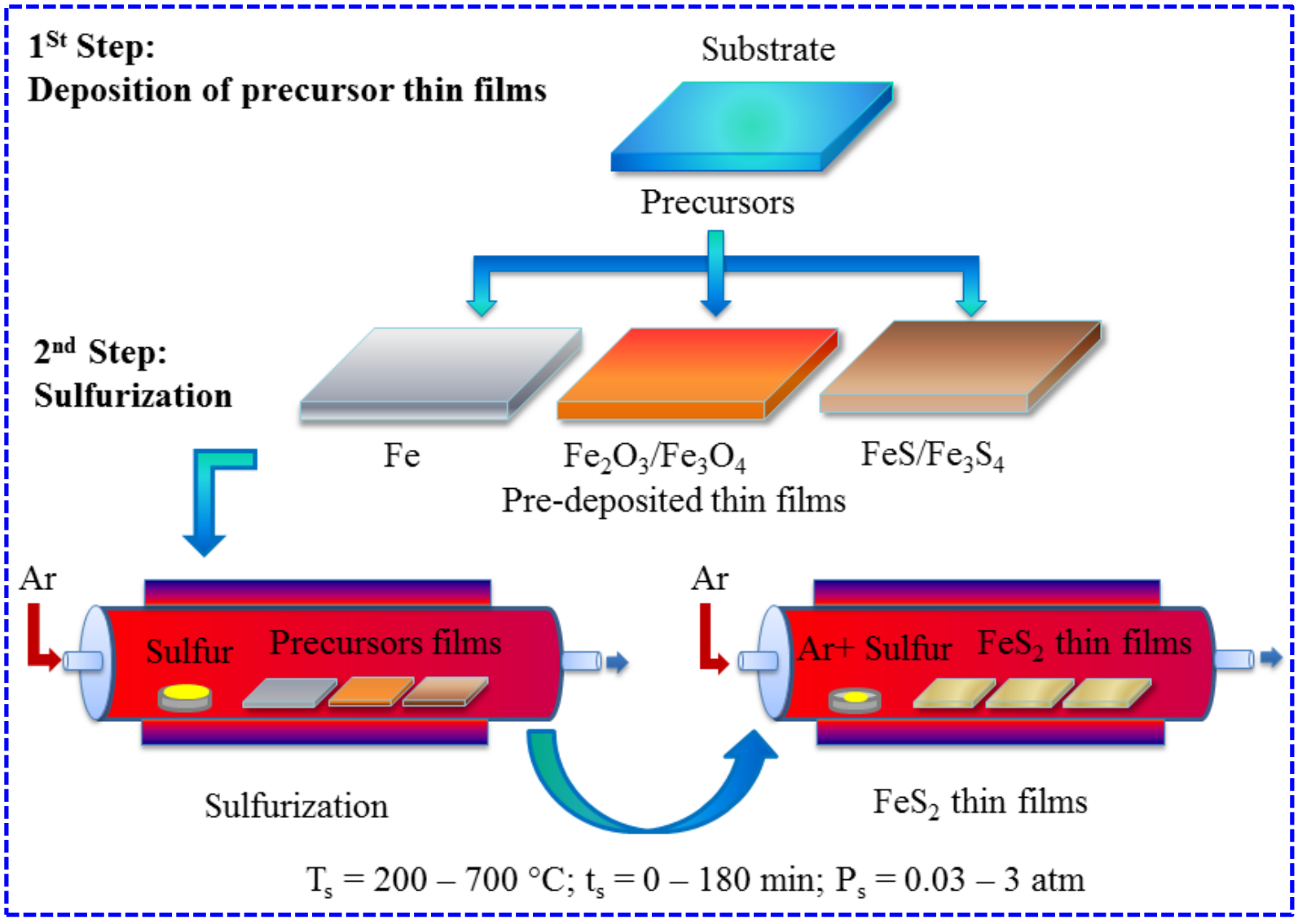

Figure 12. Schematic illustration of sulfurization process for $\mathrm{FeS}_{2}$ thin films.

In a typical spray pyrolysis technique, a precursor solution is pulverised by means of a neutral gas (e.g. nitrogen) so that it arrives at the substrate in the form of very fine droplets. The constituents react to form a chemical compound onto the substrate. The chemical reactants are selected such that the products other than the desired compound are volatile at the temperature of deposition. $^{[205]}$ 
Table 3. Pyrite thin films growth methods ${ }^{\dagger}$

\begin{tabular}{|c|c|c|c|c|}
\hline Deposition method & Single step growth & Ref. & Two step growth & Ref. \\
\hline Biosynthesis & Anaerobic & {$[206]$} & & \\
\hline \multirow{6}{*}{$\begin{array}{l}\text { Physical } \\
\text { deposition }\end{array}$} & Flash evaporation & {$[207]$} & & \\
\hline & MBE & [208] & & \\
\hline & Sputtering & [209] & Post sulfuration & [210] \\
\hline & Thermal evaporation & [211] & Post sulfuration & {$[212,213]$} \\
\hline & Laser ablation & [214] & & \\
\hline & Pulsed electron ablation & [215] & & \\
\hline \multirow{5}{*}{$\begin{array}{l}\text { Chemical } \\
\text { deposition }\end{array}$} & MOCVD & [216] & & \\
\hline & LPMOCVD & {$[217]$} & & \\
\hline & APCVD & {$[218,219]$} & & \\
\hline & AACVD & {$[220,221]$} & & \\
\hline & Pulsed PECVD & [222] & & \\
\hline \multirow[t]{13}{*}{ Chemical deposition } & Screen printing & [223] & & \\
\hline & Chemical vapour transport & [224] & & \\
\hline & Electrodeposition & & Post sulfuration & [225] \\
\hline & Chemical bath deposition & & Post sulfuration & [226] \\
\hline & Spray pyrolysis & & Post sulfuration & {$[227,228]$} \\
\hline & Solgel & & Post sulfuration & [229] \\
\hline & Spin coating & & Post sulfuration & [230] \\
\hline & Hydrothermal & [83] & & \\
\hline & Solvothermal & [231] & & \\
\hline & Hot injection method & & Spray coating & {$[138]$} \\
\hline & & & Dip coating & [194] \\
\hline & & & Spin coating & [232] \\
\hline & ALD & & & [233] \\
\hline
\end{tabular}

${ }^{\dagger}$ Metal-organic chemical vapour deposition: MOCVD, Atmospheric pressure metalorganic chemical vapour deposition: APMOCVD, Atmospheric pressure chemical vapour deposition: APCVD, Aerosol assisted chemical vapour deposition: AACVD, Pulsed plasma enhanced chemical vapour deposition : Pulsed-PECVD, Atomic layer deposition: ALD 


\section{WILEY-VCH}

Sulfur annealing of pre-deposited pyrite thin films has variety of ways. Frequently used method is annealing precursor films in sulfur atmosphere at certain atmospheric pressure in inert atmosphere. Other methods include $\mathrm{H}_{2} \mathrm{~S}$ reactive annealing, ${ }^{[234]}$ plasma assisted sulfuration, ${ }^{[235]}$ irradiation by helium-neon $(\mathrm{HeNe})$ laser (wavelength, $632.8 \mathrm{~nm}$; intensity, $6 \times$ $\left.10^{4} \mathrm{~W} / \mathrm{cm}^{2}\right),{ }^{[236]}$ neodymium-doped yttrium aluminium garnet (Nd:YAG) laser annealing. ${ }^{[237]}$ But most of the pyrite thin films have main problem of stoichiometry and phase purity. Properties and quality of pyrite thin films can be improved by using appropriate experimental method and conditions.

Cabán-Acevedo et al. ${ }^{[141]}$ reported vertically oriented single crystalline iron pyrite $\left(\mathrm{FeS}_{2}\right)$ nanowires (diameters of $4-10 \mathrm{~nm}$ and lengths of 2-6 $\left.\mu \mathrm{m}\right)$ along the [100] and [110] zone axes (ZAs) synthesized via thermal sulfidation of steel foil at $350{ }^{\circ} \mathrm{C}$ for $2 \mathrm{~h}$. They established a general scheme for Hall effect device fabrication and measurements for iron pyrite NW morphology as NWs have been especially resistant to Hall effect measurement techniques due to the repressive 1D geometry. This Hall effect measurement method was further extended to chiral magnetic MnSi nanowires. ${ }^{[238]}$ Nanowires with higher surface area (large aspect ratio) are of significant interest for energy conversion devices. ${ }^{[239]}$ Recently, Li et al. ${ }^{[151]}$ demonstrated large-scale synthesis of high-purity pyrite NWs $(\sim<20 \mathrm{~nm}$ in diameter) by sulfidation of $\sim 10 \mathrm{mg}$ of the partially dehydrated iron fluoride $\left(\alpha-\mathrm{FeF}_{3} \cdot 3 \mathrm{H}_{2} \mathrm{O}\right)$ NWs ( 30-200 $\mathrm{nm}$ in diameter) at $500{ }^{\circ} \mathrm{C}$ for $2 \mathrm{~h}$ under a sulfur atmosphere for the first time. The strong optical absorption $\left(\alpha>10^{5} \mathrm{~cm}^{-1}\right.$ for $\left.\mathrm{h} v>1.0 \mathrm{eV}\right)$ was observed by as synthesized pyrite NW film ( $500 \mathrm{~nm}$ in thickness) deposited on a borosilicate glass substrate. Previously Sunkara et al. ${ }^{[240]}$ grew $\mathrm{FeS}_{2} \mathrm{NWs}$ (diameters $20-100 \mathrm{~nm}$ ) by sulfurization $\left(25 \mathrm{sccm}\right.$ of $\mathrm{H}_{2} \mathrm{~S}$ ) of hematite $\left(\alpha-\mathrm{Fe}_{2} \mathrm{O}_{3}\right) \mathrm{NWs}(\sim$ diameters $10 \mathrm{~nm})$ at $250{ }^{\circ} \mathrm{C}$ substrate temperature in a small vacuum chamber ( $80 \mathrm{mTorr}$ ) for $1 \mathrm{~h}$. Diffusion of sulphur atoms into the lattice converting the 


\section{WILEY-VCH}

iron oxide to iron sulfide with release of oxygen atoms. Pure phase $\mathrm{FeS}_{2}$ NWs conversion solely depends on the available diffusion surface for sulphur atoms that can only be provided by NWs.

Chemical vapour deposition (CVD) has been frequently used to deposit pyrite thin films. Precursors play a vital role in CVD technique. ${ }^{[241]}$ Precursors like iron pentacarbonyl $\left[\mathrm{Fe}(\mathrm{CO})_{5}\right]$ or iron acetate $\mathrm{Fe}(\mathrm{acac})_{3}$ as iron source and hydrogen sulfide $\left(\mathrm{H}_{2} \mathrm{~S}\right)$, tert-butyl sulfide (TBS) or tert -butyl disulfide (TBDS) as the sulfur source have been used for deposition of pyrite thin films via atmospheric- or low-pressure metal-organic chemical vapour deposition (AP or LP MOCVD) respectively. ${ }^{[218,242]}$ The iron complexes of dithiocarbamates or thiobiurets as single source precursors provide single step synthesis of pyrite nanocrystals and nanocrystalline pyrite thin films. ${ }^{[243]}$

Martinolich et al. ${ }^{[244]}$ reported the salt-exchange metathesis reaction approach for the synthesis of high purity pyrite at low temperature $350{ }^{\circ} \mathrm{C}$ through intermediate pyrite phases. The significant atomic rearrangements are involved in the formation of alkali-rich metal sulfides at low temperatures following this metathesis approach. At nanoscale, Fe-S phase transformation on steel surface from sulfur deficient to iron deficient phases at low temperature $50{ }^{\circ} \mathrm{C}$ in sulfur atmosphere $\left(\mathrm{H}_{2} \mathrm{~S}\right.$ pressure $=1 \mathrm{MPa}$; reaction time $\left.=18-21 \mathrm{~h}\right)$ influenced by reaction conditions (Figure 13). The framboid-shaped cubic $\mathrm{FeS}_{2}$ crystals were observed to appear at $20 \mathrm{~h}$. The conversion of cubic $\mathrm{FeS}$ into greigite $\left(\mathrm{Fe}_{3} \mathrm{~S}_{4}\right)$ was first time observed at nanoscale. ${ }^{[245]}$ 


\section{WILEY-VCH}

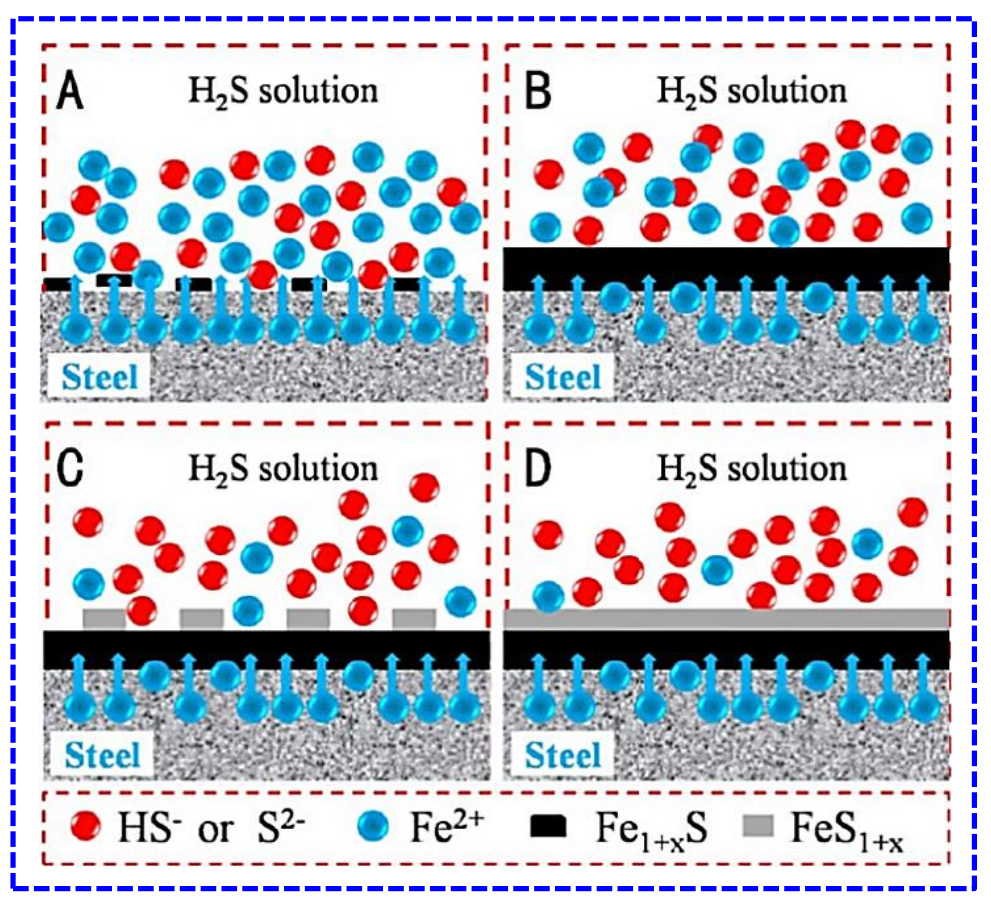

Figure 13. Schematic diagrams of the growth of iron-sulfur compounds on the steel. ${ }^{[245]}$ Reproduced with permission from ref. ${ }^{[24]}$. Copyright 2014 American Chemical Society.

Earth-abundant photovoltaic applications require pure phase pyrite thin films. Frequently used pyrite fabrication methods involve sulfuration/sulfurization of pre-deposited precursor thin films. The pure pyrite phase transformation from precursor films strongly depends on sulfurization temperature. ${ }^{[246]}$ The structural phase formation on the films occurs typically between 350 and $400{ }^{\circ} \mathrm{C}$. Relatively high temperatures and high sulfur pressures elude the phase impurities like orthorhombic $\mathrm{FeS}_{2}$ (marcasite) and monoclinic or hexagonal pyrrhotite $\left(\mathrm{Fe}_{1-} \mathrm{S}\right)$ that are frequently considered as detrimental to photovoltaic properties of pyrite. Sulfurization parameters directly influence the structural, morphological, textural, mechanical, optical and electrical properties of pyrite thin films. Lattice and thermal expansion mismatch between films and substrate contributes to tensile stress, poor adhesion and hence cracking when sulfurized thin films cools from the sulfuration temperature to room temperature. The electrical and electronic parameters are directly related to the grain size and grain boundaries and indirectly to the orientation of the grains. The grain boundaries influence the conductivity, 


\section{WILEY-VCH}

carrier concentration, carrier mobility and photo-carrier life time. Sulfurization chemistry and void-fraction engineering can support to improve microstructure i.e., crystallite size and morphology. Large crystallites can decrease carrier recombination losses at grain boundaries appealing for photovoltaic devices. The phase purity in turns properties of pyrite thin films prepared by sulfurization process are influenced by various factors, few are discussed in next sub-sections and summarised in Figure 14.

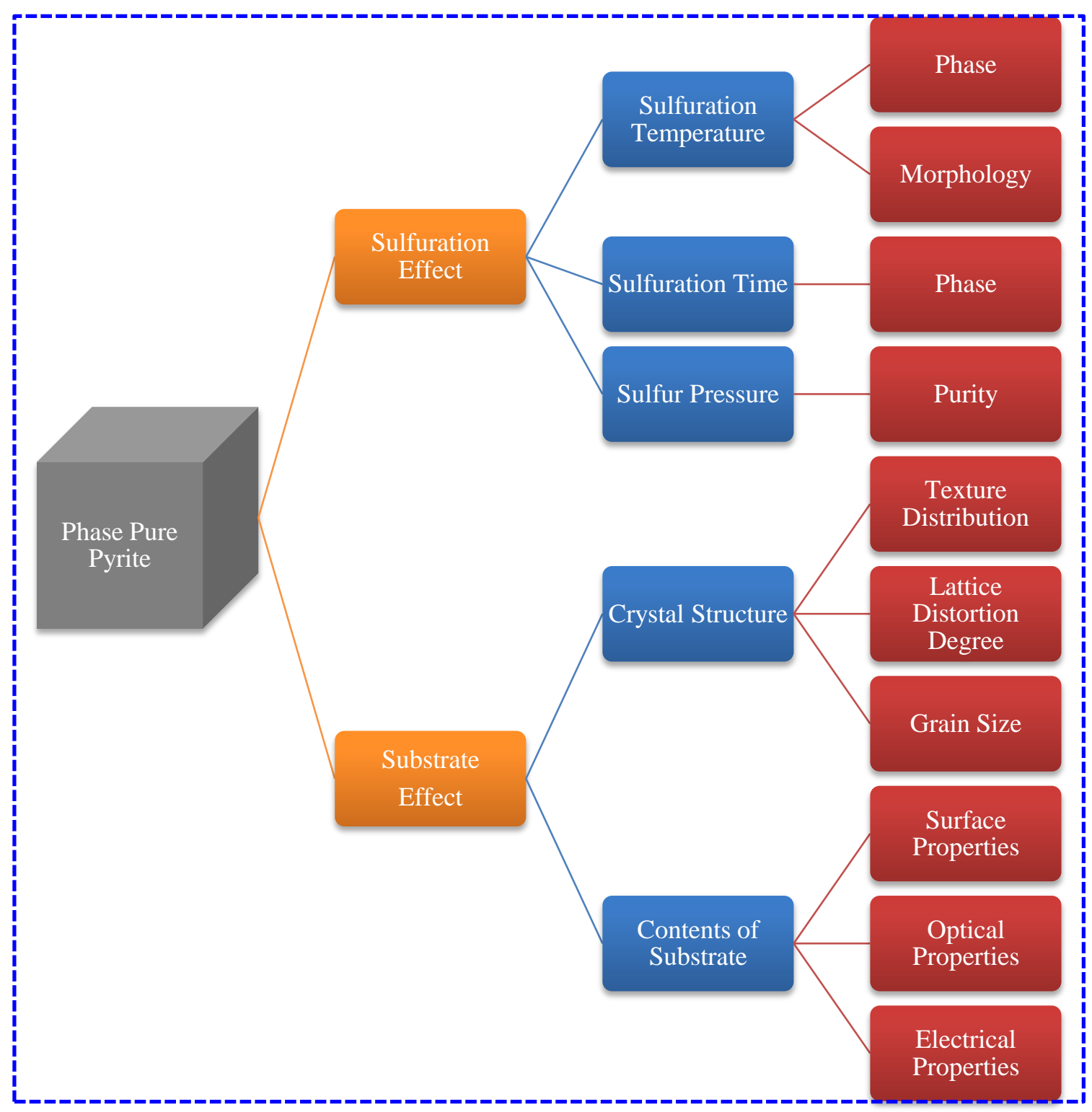

Figure 14. Factors effecting phase pure pyrite 


\section{WILEY-VCH}

\subsection{Surface and Microstructural properties}

Glass is the most frequent, financially viable and appropriate substrate for thin film deposition. Amorphous glass substrates have an insignificant effect on orientation and distribution of the film growth. ${ }^{[247]}$ Various materials have been applied as substrates for pyrite thin films e.g., glass, $\mathrm{Si}$ (100), $\mathrm{Si}$ (111), $\mathrm{SiO}_{2} / \mathrm{Si}$, ITO, FTO, $\mathrm{Al}_{2} \mathrm{O}_{3}$ (0001), Mo, Al foil, Fe foil, vitreous $\mathrm{C}$, quartz, $\mathrm{TiO}_{2}, \mathrm{CdS}, \mathrm{ZnS}, \mathrm{NaF}$, steel etc. Film texture, morphology, optical and electrical properties can be directly controlled via suitable substrates by considering energy level alignments of materials according to device design (Figure 15).

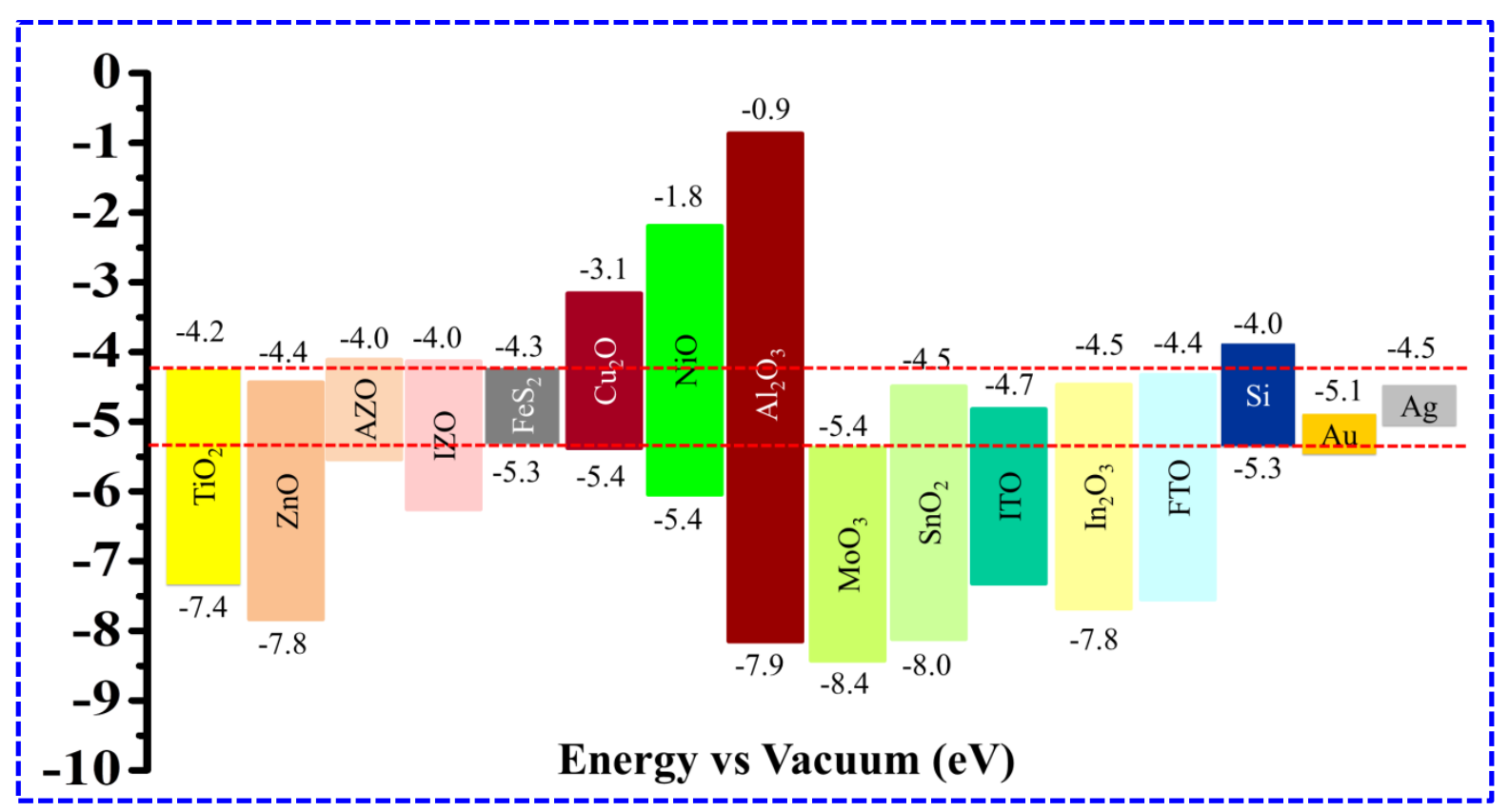

Figure 15. Schematic representation of energy level alignment between $\mathrm{FeS}_{2}$ and various materials coated glass substrates

Interfacial mismatch between substrate and thin film results in the changes of the texture distribution, lattice distortion degree and grain size. The interface strain energy, film surface energy and natural grain growth orientation altogether play a key role in the distribution of crystal orientation. The $\mathrm{Na}$ (sodium) content of the glass plays a key role in the nucleation and grain growth of pure pyrite thin films. Diffusion of $\mathrm{Na}$ (sodium leaching) from substrate also reduces marcasite impurity in pyrite thin films. It also decreases temperature and time 


\section{WILEY-VCH}

required to eradicate any residual marcasite through sulfur annealing. As the sodium content decreases in the substrate, marcasite impurity increases thus Mo-coated glass and quartz substrate showed more impurity than soda glass substrate. Similarly NaF coated quartz substrate yielded more pure pyrite thin films than uncoated quartz substrate. ${ }^{[218]}$ Marcasite impurity can be eliminated by sulfuration of as prepared pyrite thin films (Figure 16). ${ }^{[210]}$

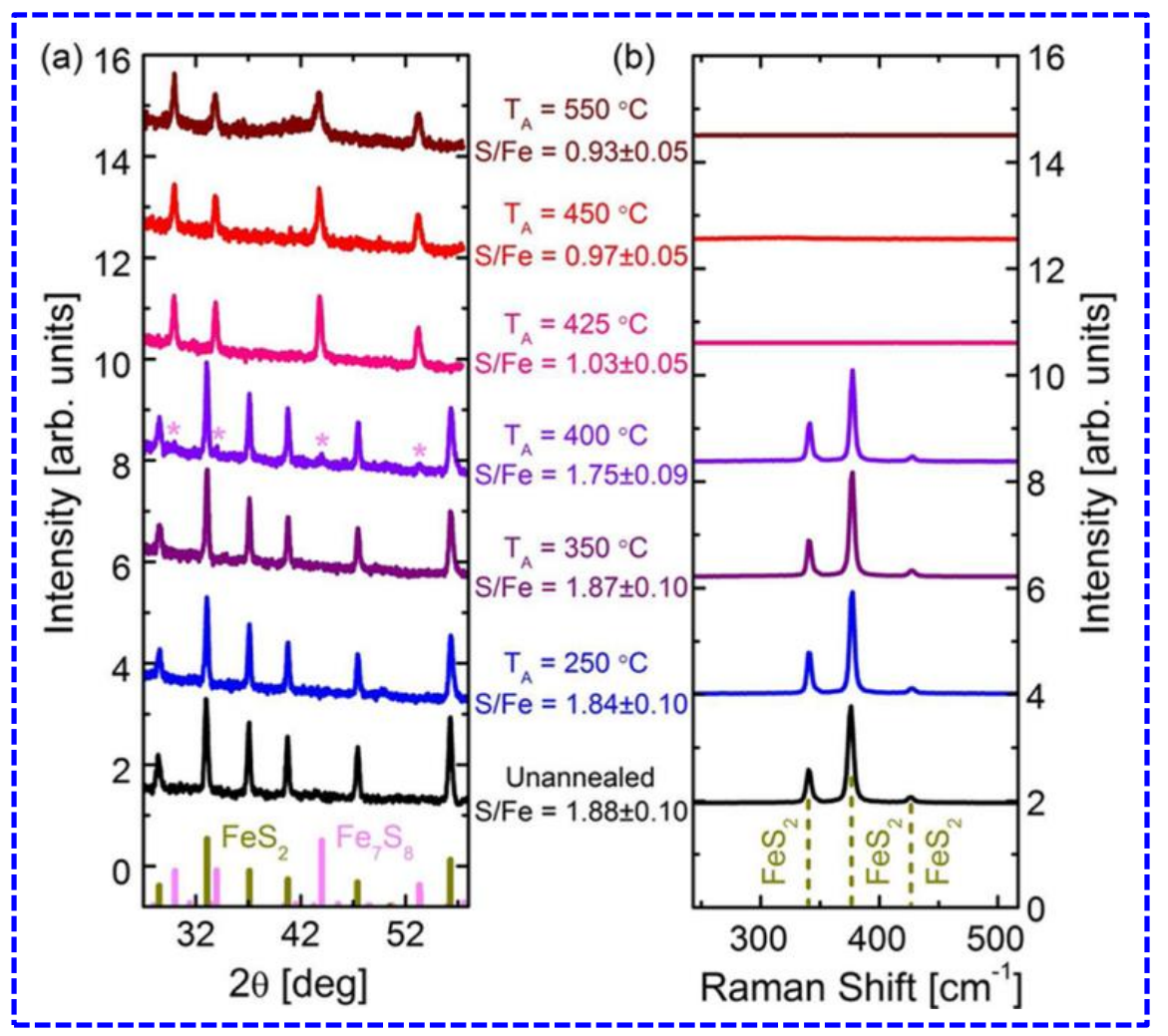

Figure 16. (a) Wide-angle $\mathrm{X}$-ray diffraction from $\mathrm{Al}_{2} \mathrm{O}_{3}(0001) / \mathrm{FeS}_{2}$ films after a $1 \mathrm{~h}$ vacuum anneal $\left(1 \times 10^{-6}\right.$ Torr $)$ at temperatures (TA) between 250 and $550{ }^{\circ} \mathrm{C}$. An unannealed film is shown for comparison. At the bottom, the green (magneta) lines show the expected pyrite $\mathrm{FeS}_{2}$ (pyrrhotite $\mathrm{Fe}_{7} \mathrm{~S}_{8}$ ) powder patterns. For $\mathrm{TA}=400{ }^{\circ} \mathrm{C}$, magneta asterisks mark reflections from pyrrhotite. (b) Raman spectra of the same films. At the bottom, the green dashed lines mark the 344, 380, and $430 \mathrm{~cm}^{-1}$ peaks expected from pyrite $\mathrm{FeS}_{2 .}{ }^{\left[{ }^{[48]}\right.}$ The pyrrhotite phase dominating at $\mathrm{TA} \geq 425^{\circ} \mathrm{C}$ is Raman inactive in this range. ${ }^{[248]}$ No marcasite $\mathrm{FeS}_{2}$ (expected peak positions $323,385,391$, and $441 \mathrm{~cm}^{-1}$ ) is detected. All plots are vertically displaced by $\sim 2$ arbitrary units for clarity. In between the panels, the S/Fe ratio from energy dispersive spectroscopy is labelled. ${ }^{[210]}$ Reproduced with permission from ref. ${ }^{[210]}$. Copyright 2015 American Chemical Society. 


\section{WILEY-VCH}

Gold substrates also showed well adhered pyrite films with uniform surface morphology and large grains. ${ }^{[53]}$ Similarly the optical properties of pyrite thin films are influenced by crystal defect density, intergranular crack amount and transformation stress level.

Larger grains of pyrite were observed on $\mathrm{Si}(100)$ and glass substrates than on $\mathrm{Al}$ and $\mathrm{TiO}_{2}$ substrates. Comparably, the distribution of the grains is more uniform in the films on $\mathrm{Si}$

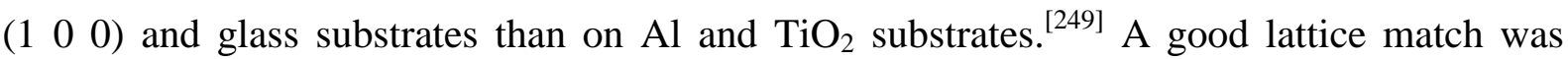
found for Si (100) substrate and large lattice distortion or high strain energy responsible for comparatively inhomogeneous microstructure for pyrite thin films deposited on $\mathrm{Al}$ and $\mathrm{TiO}_{2}$ substrates. ${ }^{[250]}$ The preferred orientation of the pyrite thin films deposited on $\mathrm{Si}$ (100), Si (111) and $\mathrm{Al}$ is along (200) plane while on $\mathrm{TiO}_{2}$ substrate preferred orientation planes were (200) and (220). $\mathrm{SiO}_{2} / \mathrm{Si}$ substrate is less reactive than $\mathrm{Al}$ substrate, so pyrite films fabricated on $\mathrm{SiO}_{2} / \mathrm{Si}$ substrate had fewer defects and smoother surfaces as compared to Al substrate. ${ }^{[214]}$ Similar results were obtained for $\mathrm{ZnS}$ substrates due to lattice mismatch or / and to somewhat low surface mobility of iron. ${ }^{[251]}$ Pyrite $\left(\mathrm{FeS}_{2}\right)$ nanocrystals (diameter $25-100 \mathrm{~nm}$ ) fabricated on indium tin oxide (ITO) substrate by using thermal reaction of iron-oleyamine complexes with sulfur in oleylamine. ${ }^{[252]}$ The changes of particle size can be attributed to the different interactions of surface energy and interface energy at different annealing temperatures. $\mathrm{FeS}_{2}$ thin films on iron foil exhibited enhanced photocurrent $\left(1.2 \mathrm{~mA} \mathrm{~cm}^{-2}\right)$ generation following light irradiation with a UV-cut off filter ranging from the visible to NIR wavelength regions. Iron foil substrate was found to be a good lattice-matched for the growth of $\mathrm{FeS}_{2}$ thin films flexibly applicable to low cost scalable photovoltaic device fabrication. ${ }^{[253]}$

Sulfurization of precursor films at high temperature improves thin film growth and the pure phase pyrite. Optimum sulfuration temperature for these films varies from 200 to $700{ }^{\circ} \mathrm{C}$. 


\section{WILEY-VCH}

The main process during pyrite formation at particular sulfuration temperature e.g., $400{ }^{\circ} \mathrm{C}$ is diffusion of sulfur into iron oxide $\left(\mathrm{Fe}_{2} \mathrm{O}_{3}\right.$, thickness of $\left.400 \mathrm{~nm}\right)$ thin film (substitution of oxygen by sulfur). The precursor $\mathrm{Fe}_{2} \mathrm{O}_{3}$ films fabricated by successive ionic layer adsorption and reaction (SILAR) transformed into $\mathrm{FeS}_{2}$ with thickness of about $500 \mathrm{~nm}$ after sulfurization. The sulfurized films with direct band gap $0.75 \mathrm{eV}$ and indirect band gap 1.19 $\mathrm{eV}$ showed a high optical absorption coefficient $\alpha>10^{5} \mathrm{~cm}^{-1}$ in visible and near-infrared regions. Hall measurements revealed that films were P-type having positive Hall coefficient with electrical resistivity of $0.58 \Omega \mathrm{cm}$, carrier concentration of $2.5 \times 10^{18} \mathrm{~cm}^{-3}$ and Hall mobility of $11.8 \mathrm{~cm}^{2} \mathrm{~V}^{-1} \mathrm{~s}^{-1}$ at $298 \mathrm{~K}$. The films exhibited strong photocurrent response with good photostability essential for photovoltaic devices. ${ }^{[254]}$

Iron pyrite films have been prepared by sulfuration of columnar iron films (thickness $=$ $200 \mathrm{~nm}$ ) grown on $\mathrm{Si}(100)$ substrate under sulfur $\mathrm{S}_{8(\mathrm{~g})}(200-250 \mathrm{mg})$ pressure of $80 \mathrm{kPa}$ at $450{ }^{\circ} \mathrm{C}$. The sulfurized films were uniform and crack-free with crystallite sizes $>100 \mathrm{~nm}$ having facetted granular microstructure. The microstructural evolution and fabrication of crack-free films are greatly influenced by inter-column spacing, deposition angle, and the film thickness. The indirect band gap of films estimated to be $0.98 \pm 0.04 \mathrm{eV}$ having resistivity of $2.2 \Omega \mathrm{cm}$ and carrier mobility on the order of $0.1 \mathrm{~cm}^{2} \mathrm{~V}^{-1} \mathrm{~s}^{-1}$ with majority carrier concentrations in the range of $10^{18} \mathrm{~cm}^{-3}$ to $10^{19} \mathrm{~cm}^{-3}$. The lifetime of photo-carriers was measured as 27 ps with ultrafast optical-pump/THz-probe as high efficiency devices require longer carrier life time. ${ }^{[255]}$

Grain boundary model ${ }^{[256,257]}$ explains the lowering of potential barrier at the grain boundaries in thicker films that is due to the decreased defect concentration. As a consequence it provides more charge carriers. Secondly thick films with fewer grain boundaries and large grain size deteriorate the confinement of charge carriers by grain 


\section{WILEY-VCH}

boundaries and results the higher carrier density and Hall mobility. The effect of film thickness on the lattice distortion can be determined by measuring lattice distortion degree given by equation (2): ${ }^{[258]}$

$$
\delta=\frac{a-a_{o}}{a_{o}}
$$

Where $a_{o}=0.5418 \mathrm{~nm}$ is lattice constant of pyrite and $a$ is the calculated lattice constant from XRD data of the films. As the film thickness increases, grain boundary area and number of vacancies increase due to increase in lattice distortion and reduce crystallite size. Carrier density and Hall mobility increase with increasing film thickness. Scanning electron microscopy (SEM) images of $\mathrm{FeS}_{2}$ films prepared by ex-situ sulfidation (sulfidation temperatures, $\mathrm{T}_{\mathrm{S}}=200-700{ }^{\circ} \mathrm{C}$ ) of Fe films (thickness $=33 \mathrm{~nm}$ ) on $\mathrm{Al}_{2} \mathrm{O}_{3}(0001)$ via D.C. magnetron sputtering from $\mathrm{Fe}$ target. At $\mathrm{T}_{\mathrm{S}}=400{ }^{\circ} \mathrm{C}$, somewhat smooth polycrystalline films were observed comprising monodisperse grains of $\sim 60 \mathrm{~nm}$ diameter. As the $\mathrm{T}_{\mathrm{S}}$ increases above $350{ }^{\circ} \mathrm{C}$, the grain size increases accompanied by increase in surface roughness. The films sulfidized at $\mathrm{T}_{\mathrm{S}}=600{ }^{\circ} \mathrm{C}$ (Figure 17d,i) are a monolayer of $\mathrm{FeS}_{2}$ grains of $\sim 100 \mathrm{~nm}$ diameter, a desirable microstructure for PV applications. The discontinuity and delamination occur at even higher $\mathrm{T}_{\mathrm{S}}=700{ }^{\circ} \mathrm{C}$ (Figures 17e,j) in the pyrite decomposition temperature range $\left(723{ }^{\circ} \mathrm{C}\right) .{ }^{[259]}$ 


\section{WILEY-VCH}

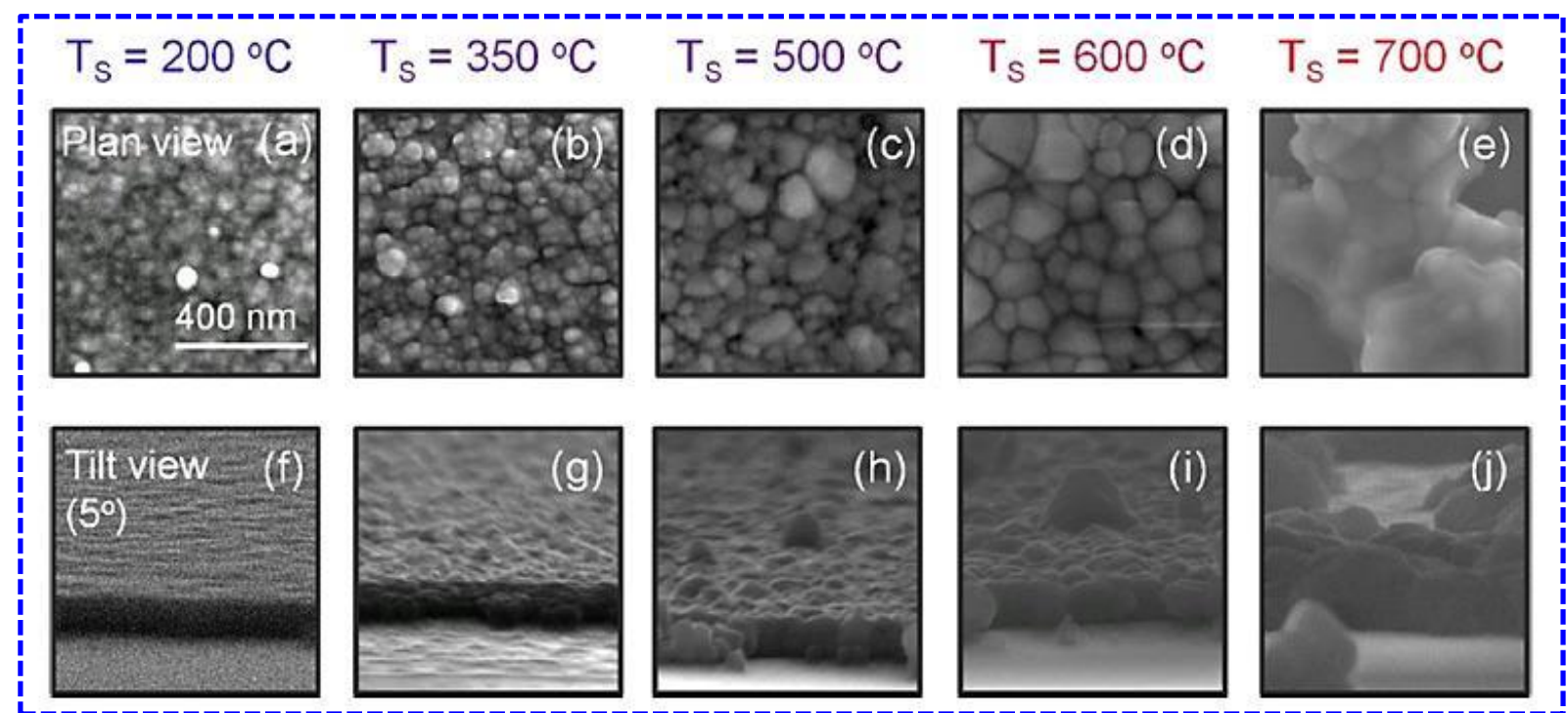

Figure 17. Scanning electron microscopy. Plan-view $(\mathrm{a}-\mathrm{e})$ and tilt-view $\left(5^{\circ}\right.$ from the substrate plane, ( $\mathrm{f}-\mathrm{j})$ ) secondary electron SEM images (15 $\mathrm{kV}$ accelerating voltage) of $\mathrm{Al}_{2} \mathrm{O}_{3}(0001) / \mathrm{Fe}$ films (original thickness $33 \mathrm{~nm}$ ) sulfidized at representative temperatures of 200, 350, 500, 600, and $700{ }^{\circ} \mathrm{C} .{ }^{[259]}$ Reproduced with permission from ref. ${ }^{[259]}$. Copyright 2013 American Chemical Society.

Pyrite thin films showed high conductivity and high carrier concentration for thin films. The carrier mobility increased as film thickness increased from 70-300 $\mathrm{nm}$ and then declined for the film with $>300 \mathrm{~nm}$ thickness. Grain growth by sulfuration of the films depends on the following parameters given by equation (3): ${ }^{[260]}$

$$
D^{n}-D_{o}^{n}=C(T) \cdot t=C_{o} \cdot t \cdot \exp ^{-\frac{E}{k T}}
$$

Where $D_{o}$ is the grain size at $\mathrm{t}=0, \mathrm{~T}$ is the temperature, $D$ is the enhanced grain size at time $\mathrm{t}$, $E$ is the activation energy of the growth process. As the sulfuration temperature $\left(T_{s}\right)$ increases the lattice expansion occur by diffusion of sulfur atoms in the pre-deposited films. Low sulfuration temperature is followed by the rapid crystallites growth. Subsequently, structural properties of pyrite thin films via sulfuration of precursor thin films are determined by sulfuration conditions e.g., sulfur pressure, temperature and time. The phase transformation from $\mathrm{Fe}_{2} \mathrm{O}_{3}$ into $\mathrm{FeS}_{2}$ tracked using Raman spectroscopy (Figure 18). The direct optical band gap reduced from $2.2 \mathrm{eV}\left(\mathrm{Fe}_{2} \mathrm{O}_{3}\right)$ to $1.2 \mathrm{eV}\left(\mathrm{FeS}_{2}\right)$ and indirect optical band gap was measured 


\section{WILEY-VCH}

between $0.95-1.0 \mathrm{eV}$. The sulfurized pyrite films exhibited ohmic behaviour with dark conductivity of $1.1 \times 10^{-4} \mathrm{Scm}^{-1}$. The conductivity can be scaled with critical parameter of grain size for high-quality solar absorbers. The conductivity of films was $2.3 \times 10^{-4} \mathrm{Scm}^{-1}$ under AM 1.5 light source illumination highlighting a promising photoresponse of pyrite as a solar absorber. ${ }^{[218,261]}$

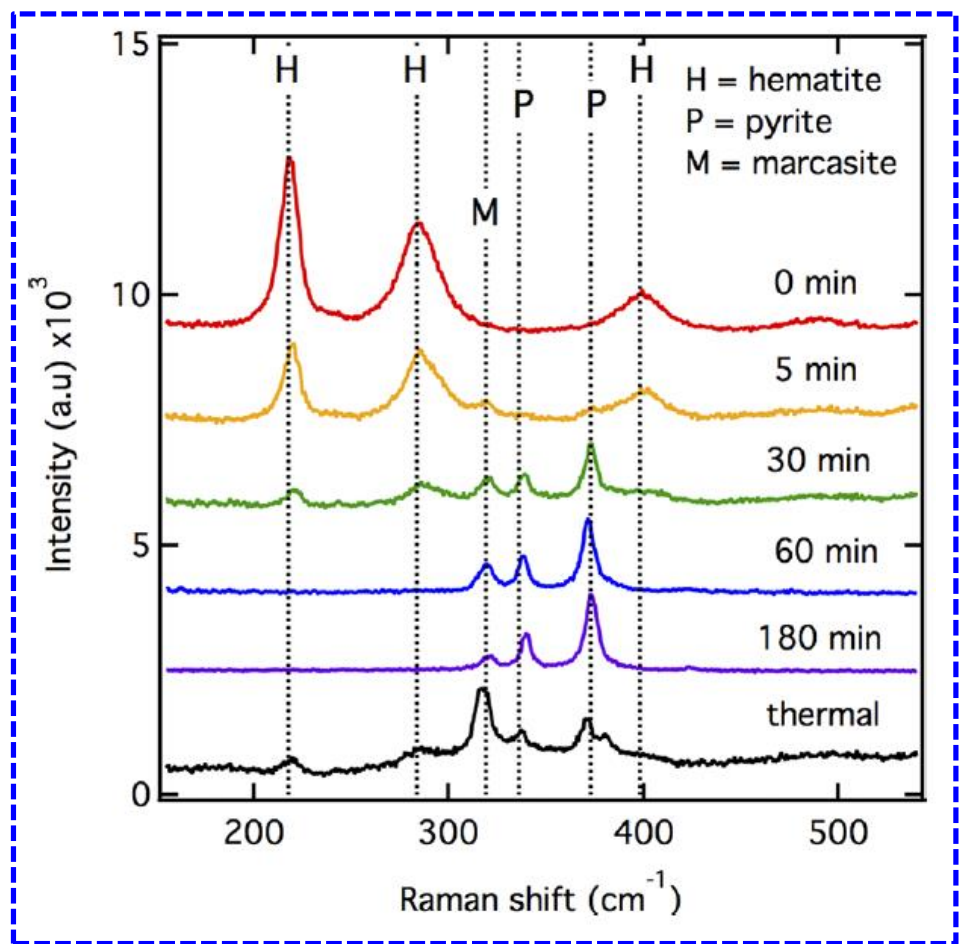

Figure 18. Raman spectra of $\mathrm{Fe}_{2} \mathrm{O}_{3}$ nanorods sulfurized at $400{ }^{\circ} \mathrm{C} .{ }^{[261]}$ Reproduced with permission from ref. ${ }^{[261]}$. Copyright 2012 American Chemical Society.

The crystal defect density is another parameter for determination of electrical properties of pyrite thin films. The crystal defect density is governed by the crystallizing status of the precursor films or the crystallinity and continuity of the pyrite films. The layer-by-layer growth of stoichiometric, single-phase pyrite thin films on heated Si (100) substrates using sequential evaporation of $\mathrm{Fe}$ under high vacuum followed by sulfidation at pressures ranging from 1 mTorr to 1 Torr revealed high-quality, defect-free pyrite grains. ${ }^{[262]}$ Moon et al. ${ }^{[228]}$ estimated the partial pressure of sulfur during sulfurization considering the ratio between the partial pressure of $\mathrm{S}$ inside the container after equilibration $\left(\mathrm{P}_{\mathrm{S}, \text { eq }}\right)$ and $\mathrm{P}_{\text {total }}$ by equation (4): 


\section{WILEY-VCH}

$$
P_{S, \text { eq,actual }}=P_{\text {total,actual }}(760 \text { torr }) \times \frac{P_{S, e q}}{P_{\text {total }}}
$$

They noticed that $\mathrm{P}_{\mathrm{S} \text {, eq,actual }}$ is same 378.5 Torr at all temperatures due to the pressure limit. $\mathrm{P}_{\text {total }}$ under background pressure $\left(\mathrm{P}_{\mathrm{N}, \mathrm{RT}}\right)$ of $10^{-3}$ Torr is lower than the pressure limit. Consequently, $\mathrm{P}_{\mathrm{S}}$, eq is equal to $\mathrm{P}_{\mathrm{S}}$, eq,actual $=206.9$ Torr at $450{ }^{\circ} \mathrm{C}$. Therefore, the phase evolution behaviour is certainly temperature dependent under the same partial pressure of S. Pyrite can be completely converted to marcasite by annealing mixed-phase $\mathrm{FeS}_{2}$ films at temperatures higher than $500{ }^{\circ} \mathrm{C}\left(500-550{ }^{\circ} \mathrm{C}\right)$ and larger sulfur partial pressures with film texturing equiaxed grains (Figure 19). Annealing at temperatures higher than $600{ }^{\circ} \mathrm{C}$ in sulfur ambient showed immoderate grain growth with surface roughening and pinhole formation. ${ }^{[218]}$

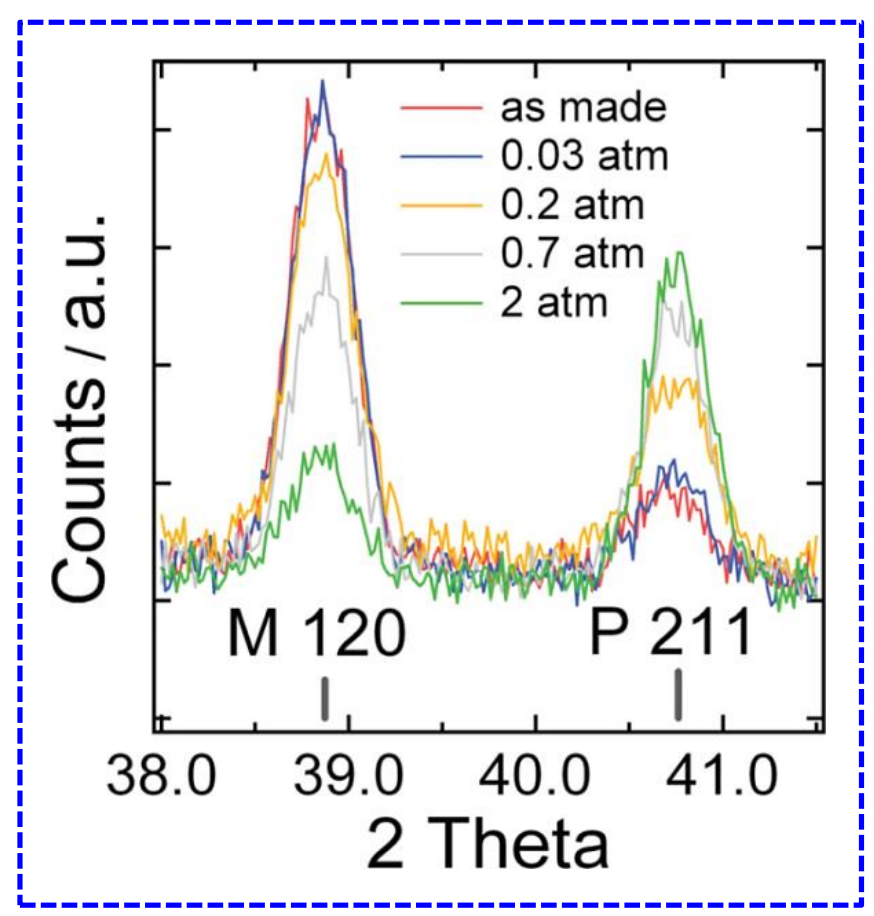

Figure 19. Effect of sulfur partial pressure on the marcasite-to-pyrite phase conversion during annealing. XRD scans $\left(2 \Theta=38.0-41.5^{\circ}\right.$, showing the marcasite 120 and pyrite 211 reflections) of five identical mixed-phase $\mathrm{FeS}_{2}$ films on quartz substrates annealed at $550{ }^{\circ} \mathrm{C}$ for $2 \mathrm{~h}$ in various pressures of sulfur vapour. Marcasite conversion to pyrite is more rapid and complete at larger sulfur partial pressures. $(\mathrm{M}=$ marcasite; $\mathrm{P}=$ pyrite. $){ }^{[218]}$ Reproduced with permission from ref. ${ }^{[218]}$. Copyright 2012 John Wiley \& Sons, Inc. 


\section{WILEY-VCH}

\subsection{Optical properties}

All chemical synthetic routes provide specific way towards nano-sized thin films fabrication. Reduction in the grain size of films results in the higher optical absorption and electrical resistivity. As the thickness of the films increases, the absorption edge shifts towards ideal values. Intergranular cracks and crystal defect density eventually affect the optical properties of pyrite thin films. ${ }^{[263]}$ Sulfurization of $\mathrm{Fe}_{3} \mathrm{~S}_{4}$ rice like nanocrystal (diameters $25-130 \mathrm{~nm}$ ) films (thickness $=500 \mathrm{~nm}$ ) yielded phase pure pyrite with two absorption edges at 0.9 (indirect) and $1.2 \mathrm{eV}$ (direct). ${ }^{[204]}$ The absorption coefficient $(\alpha)$ of the iron sulfide thin films (thickness; $\mathrm{d}=200 \mathrm{~nm}$ ) deposited on glass substrate was calculated before and after sulfurization at room temperature by equation (5):

$$
\alpha=\ln [(1-R) / T] / d
$$

Where $\mathrm{T}$ is transmittance and $\mathrm{R}$ is reflectance. Thermal sulfurization improves crystallinity, uniformity and the surface/interface smoothness of thin films consequently enhances optical properties of thin films. ${ }^{[204]}$

The optical band gap $\left(\mathrm{E}_{\mathrm{g}}\right)$ can be calculated by Tauc equation $(6):^{[264]}$

$$
\alpha h v=A\left(h v-E_{g}\right)^{n}
$$

Where $h v$ is the photon energy, $\alpha$ is the absorption coefficient, $A$ is constant, $n=2$ for an indirect allowed transition and $n=1 / 2$ for direct allowed transition. Thicker films with enlarged grain size have lower band gap values while quantum confinement effect enhances bandgap value. ${ }^{[265]}$ The pyrite absorption edge is assigned to a transition between the $\mathrm{Fe} 3 \mathrm{~d}\left(\mathrm{t}_{\mathrm{ag}}\right)$ and $\mathrm{e}_{\mathrm{g}}$ states and temperature dependent bandgap for several semiconductors given by the empirical Varshni relation (7): ${ }^{[266]}$

$$
E_{0}(T)=E_{0}(0)-a \frac{T^{2}}{T+b}
$$




\section{WILEY-VCH}

where optical absorption edge at $0 K$ for pyrite thin films associated to the direct transition calculated by using equation 7 as $E_{0}(0)=1.048 \pm 0.005 \mathrm{eV}$ and $a=5.88 \mathrm{eV} \mathrm{K}^{-1}$ \& $b=6 \times 10^{6} \mathrm{~K}$.

The second relation between $E_{0}$ and $T$ can be expressed by Bose-Einstein equation (8):

$$
E_{0}(T)=\alpha-\beta\left(1+\frac{2}{\exp (\Theta / T)-1}\right)
$$

where $\Theta$ - the strength of the electron-phonon interaction and $\mathrm{T}$ - average temperature of phonons taking part in the process.

The optical absorption edge calculated for pyrite thin films using equation 8: $E_{0}(0)=$ $1.045 \pm 0.005 \mathrm{eV}, \Theta=568+10 \mathrm{~K}$ and empirical parameters $\alpha=1.20 \mathrm{eV} \& \beta=$ $0.154 \mathrm{eV}$. Absorption edge $\left(E_{0}\right)$ values varied from 1.05 to $0.99 \mathrm{eV}$ in temperature range 100-300 K.

Recently the optical gap was found to show the same decreasing trend from $1.00 \mathrm{eV}$ at $80 \mathrm{~K}$ to $0.94 \mathrm{eV}$ at $300 \mathrm{~K}$ and $0.86 \mathrm{eV}$ at $440 \mathrm{~K}$ by Limpinsel et al. ${ }^{[267]}$ They calculated roomtemperature band gaps from the $\sigma(\mathrm{T})$ data using three different approaches. The first approach for a temperature-independent $E_{\mathrm{g}}$ used following simple relation (9):

$$
\sigma(T)=A \exp \left(\frac{-E_{g}}{2 k T}\right)
$$

The Arrhenius fits to the intrinsic region yielded band gaps. In the other two approaches employed numerical model to fit the intrinsic $\sigma(\mathrm{T})$ data to determine $\mathrm{E}_{\mathrm{g}}$ at high temperature. The temperature dependence of $\mathrm{E}_{\mathrm{g}}$ was determined by measuring the optical gap of thin polished pyrite crystals from 80 to $440 \mathrm{~K}$ using transmission spectroscopy (Figure 20). Although their calculated value is rather smaller than the optical gap $(0.94 \mathrm{eV})$, it is still large enough to support a photovoltage of $450-500 \mathrm{mV}$ in pyrite photocells. They concluded that the pyrite photovoltage is not limited to $\sim 200 \mathrm{mV}$ by a small bulk band gap. ${ }^{[267]}$ 


\section{WILEY-VCH}

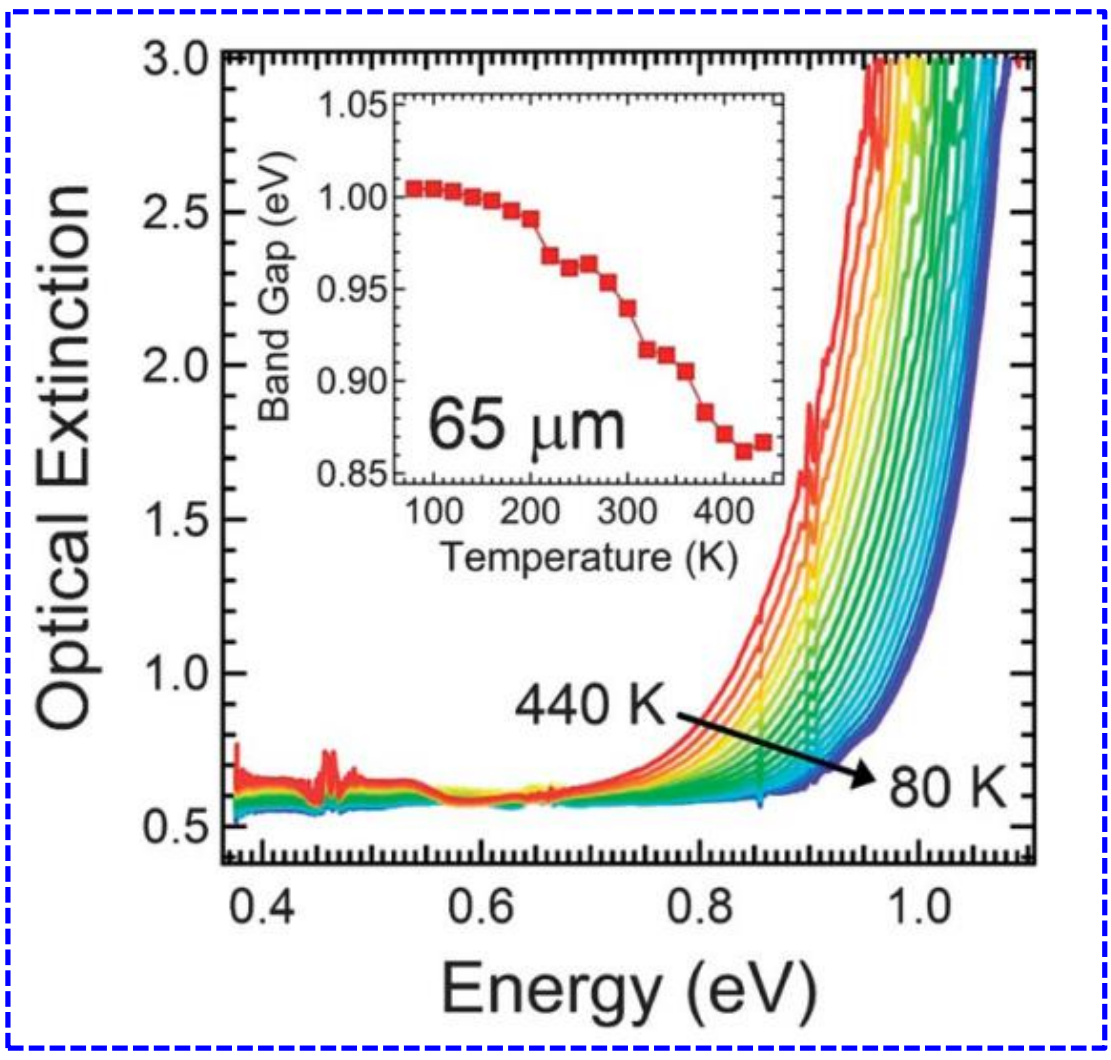

Figure 20. Optical extinction spectra of a $65 \mathrm{~mm}$ thick pyrite crystal as a function of temperature $(80-440 \mathrm{~K})$. Inset is a plot of $\mathrm{E}_{\mathrm{g}}$ versus temperature as determined by linear extrapolation of the absorption coefficient data after correcting for dispersion of the refractive index. If Tauc plots are used instead, $\mathrm{E}_{\mathrm{g}}$ is about $50 \mathrm{mV}$ higher (lower) for the direct (indirect) Tauc plot, while the temperature dependence of $E_{g}$ is unaffected. ${ }^{[26]}$ Reproduced with permission from ref. ${ }^{[267]}$. Copyright 2014 Royal Society of Chemistry.

Ferrer et al. ${ }^{[268]}$ found the lower values of real refractive index $(<3.2)$ due to light scattering effects in pyrite thin films. They estimated real refractive index $(n)$ by following equation (10): ${ }^{[269]}$

$$
n=\frac{m \lambda}{2 d}
$$

Where $m=\frac{k d}{\pi}=$ angular argument; $k=\frac{2 \pi n}{\lambda}=$ wave number,

$\lambda=$ wavelength and $d=$ thickness of the film.

Later De las Heras et al. ${ }^{[270]}$ used Cauchy expansion to evaluate refractive index of pyrite thin films given by equation (11):

$$
n=a+\frac{b}{\lambda^{2}}
$$




\section{WILEY-VCH}

They considered a hetero-structure: pyrite thin film and substrate. Refractive indices of pyrite and glass substrate are given by following relations respectively:

Real part $\quad: n=n-i k$

Imaginary part $\quad: \quad k=\frac{\alpha \lambda}{4 \pi}$

Refractive index of glass substrate $: n_{s}=1.50$

The refractive index values of pyrite thin films computed at $\lambda=1.24 \mu \mathrm{m}$ in their research work yielded values of $\mathrm{n}=3.2-3.8$ which shows clearly no dependence on growth parameters i.e., sulfuration temperature or thickness of films.

\subsection{Transport properties}

Transport properties of un-doped pyrite thin films like metallic chalcogenides are controlled by intrinsic lattice defects created during film growth. Iron (Fe) and sulfur (S) vacancies are two types of intrinsic defects in pyrite thin films. Fe vacancies act as accepters (generate holes) and S vacancies act as donors (generate electrons). ${ }^{[271]}$ Gomes et al. ${ }^{[272]}$ calculated conduction in two band system and gave formulae for Seebeck coefficient (S); equation (12), Hall coefficient $\left(\mathrm{R}_{\mathrm{H}}\right)$; equation (13) and electrical conductivity $(\sigma)$; equation (14) in terms of charge carriers and their mobilities.

$$
\begin{gathered}
S=-\frac{k_{B}}{e} \times\left\{\frac{\frac{n}{p} \frac{\mu_{n}}{\mu_{p}}-1}{\frac{n \mu_{n}}{p \mu_{p}}+1}\left(2+\frac{E_{G}}{2 k_{B} T}\right)+\frac{3}{4} \ln \frac{m_{n}}{m_{p}}-\frac{1}{2} \ln \frac{n}{p}\right\} \\
R_{H}=\frac{p \mu_{p}^{2}-n \mu_{n}^{2} e}{e\left(\mu_{p} p e-n \mu_{n} e\right)^{2}} \\
\sigma=e\left(\mu_{n} n+\mu_{p} p\right)
\end{gathered}
$$

where $n$ and $p$ are calculated charge carrier densities, $m_{n}$ and $m_{p}$ are effective masses, $\mu_{n}$ and $\mu_{p}$ are mobilities of electrons and holes respectively, $E_{G}=0.95 \mathrm{eV}$ is band gap energy, $T$ is absolute temperature, $c$ is velocity of light and e is the electron charge. 


\section{WILEY-VCH}

Arrhenius equation defines conductivity in terms of temperature and activation energy given by equation (15):

$$
\left(\frac{\sigma}{\sigma_{0}}\right)=e^{-(\Delta E / k T)}
$$

where $\sigma_{0}$ is constant, $\sigma$ is electrical conductivity, $\mathrm{k}$ is Boltzmann constant and $\mathrm{T}$ is absolute temperature. Grain boundary theory developed by different researchers led to the law of conductivity variation with the reciprocal temperature as given by (16):

$$
\sigma T^{n} \alpha e^{(-q \phi / k T)}
$$

where $\phi$ is the barrier hight at grain boundary and $n$ varies from $1 / 2$ to 1 for grain models developed by Seto ${ }^{[256]}$ and Baccarini. ${ }^{[273]}$ The activation energy varies with temperature and depends on pyrite thin films thickness, deposition method, and composition of thin films. According to these models thermionic emission is responsible for the diffusion of carriers through potential barrier and thus for crossing the barrier at high temperatures. Ouretani et $a l .^{[274]}$ reported hopping mechanism in pyrite thin films at low temperatures due to small activation energy. At low temperatures two type of hopping conduction mechanisms are possible: Mott model $\left(\mathrm{T}^{-4} \text { law }\right)^{[275]}$ and Efros model $\left(\mathrm{T}^{-1 / 2}\right.$ law). ${ }^{[276]}$ On the other hand grain distribution also affects conduction mechanism. ${ }^{[277]}$

Seebeck coefficient of pyrite thin films determines the type of thin films (n or p-type) while the sign of the Hall coefficient explain the conduction type. Reduced grain size with more grain boundaries result in the high electrical resistivity $(\rho)$. Ares et al. ${ }^{[278]}$ reported resistivity of non-stoichiometric pyrite thin films follow Arrhenius trend at temperatures higher than room temperature (RT) and can be expressed in terms of Gaussian distribution of energy levels assuming $\left[\mathrm{V}_{\mathrm{s}}<\mathrm{V}_{\mathrm{Fe}}\right]$ given by (17):

$$
\rho=\rho_{o} \exp \left[\frac{E_{m}}{k}\left(\frac{1}{T}\right)-\frac{\sigma_{E}^{2}}{2 k^{2}}\left(\frac{1}{T}\right)^{2}\right]
$$




\section{WILEY-VCH}

where $E_{m}$ is the mean energy of the level band created by iron vacancies ranging from $\sim 0.10$ $\mathrm{eV}-\sim 0.15 \mathrm{eV}$ depending on film fabrication conditions and $\sigma_{E}$ is the standard deviation which is $\sim 0.05$. He also proposed that conductivity of pyrite thin films at high temperature is primarily controlled by thermally excited electrons from valence band to the noncompensated iron vacancy accepter levels and at low temperature some hopping mechanism is involved.

Morsli et al. ${ }^{[279]}$ measured electrical conductivity $\left(\sigma \approx 0.7 \Omega^{-1} \mathrm{~cm}^{-1}\right.$ at $300 \mathrm{~K}$ with activation energy, $\left.E_{a}=90 \mathrm{meV}\right)$ and thermoelectric power, Seebeck coefficient $(\mathrm{S}=-100$ $\mu \mathrm{VK}^{-1}$ at $\left.300 \mathrm{~K}\right)$. They explained their findings in low and high temperature range on the basis of two band model. Later Cabán-Acevedo et al. ${ }^{[280]}$ investigated the temperature dependence of resistivity in two different conduction regimes explained below. Similar results were found as before: high temperature regime is dominated by thermal activation of majority carriers (18):

$$
\rho=\rho_{0} \exp \left(E_{a} / k_{B} T\right)
$$

where activation energy, $E_{a}=226 \pm 6 \mathrm{meV}$

and the Hall coefficient at room temperature is (19):

$$
R_{H}=1 / N \cdot e
$$

where bulk free electron concentration, $\mathrm{N}=1.1 \times 10^{15} \mathrm{~cm}^{-3}$

The density of donor states $\left(\mathrm{N}_{\mathrm{D}}\right)$ using the classical assumption that the ionization of donor states $\left(\mathrm{N}_{\mathrm{D}}^{+}\right)$follows a Fermi-Dirac distribution (20):

$$
N_{D}^{+}\left(E_{F}\right)=\frac{N_{D}}{1+g_{D} \exp \left(\left(E_{F}-E_{D}\right) / k_{B} T\right)}
$$

where $E_{F}=$ bulk Fermi level,

degeneracy of the donor states, $g_{D}=4$ 
the effective density of states at the conduction band edge, $N_{C}=3 \times 10^{18} \mathrm{~cm}^{-3}$

the energetic position of the donor state below the conduction band edge, $E_{D}=452 \pm$ $12 \mathrm{meV}$

the density of donor states, $N_{D}=(7.6 \pm 3.3) \times 10^{19} \mathrm{~cm}^{-3}$

for singly degenerated deep donor state, $N_{D}=(1.14 \pm 0.49) \times 10^{20} \mathrm{~cm}^{-3}$ or triply degenerated deep donor state, $N_{D}=(3.8 \pm 1.6) \times 10^{19} \mathrm{~cm}^{-3}$

Hoping conduction in the low temperature regime can be expressed in terms of resistivity (21):

$$
\rho=\rho_{0} \exp \left(\frac{T_{0}}{T}\right)^{\frac{1}{4}}
$$

Where $T_{0}=4.8 \times 10^{6} \mathrm{~K}=$ characteristic temperature

$\rho_{0}=$ constant or weakly temperature dependent factor

Low temperature Hall coefficient $\left(R_{H}\right)$ can be determined in terms of conduction band $\left(\sigma_{c}, R_{c}\right)$ or hopping $\left(\sigma_{h}, R_{h}\right)(22)$ :

$$
R_{H}=\frac{\sigma_{c}^{2} R_{c}-\sigma_{h}^{2} R_{h}}{\left(\sigma_{c}+\sigma_{h}\right)^{2}}
$$

As reported by Seefeld et al. ${ }^{[230]}$, the $\mathrm{FeS}_{2}$ nanocrystal films behave according to the Werner model $^{[281]}$ based on a Gaussian distribution of barrier heights as follows (23):

$$
P(\Phi)=\frac{1}{\sigma_{\Phi} \sqrt{2 \pi}} \exp \left(-\frac{(\bar{\Phi}-\Phi)}{2 \sigma_{\Phi}^{2}}\right)
$$

where $\bar{\Phi}=$ mean barrier height

and $\sigma=$ standard deviation.

The Werner model explains that the transport properties in polycrystalline films are limited by thermionic emission across inhomogeneous grain boundaries. Thus the temperature dependent resistivity can also be expressed as (24): 


\section{WILEY-VCH}

$$
\rho=\rho_{o} \exp \left[q\left(\frac{\Phi}{k T}-\frac{q \sigma_{\Phi}^{2}}{2 k^{2} T^{2}}\right)\right]
$$

Resistivity as a function of temperature for before (mixed phase: pyrite with marcasite impurity) and after sulfur annealing (pure pyrite) is shown in Figure 21. ${ }^{[230]}$

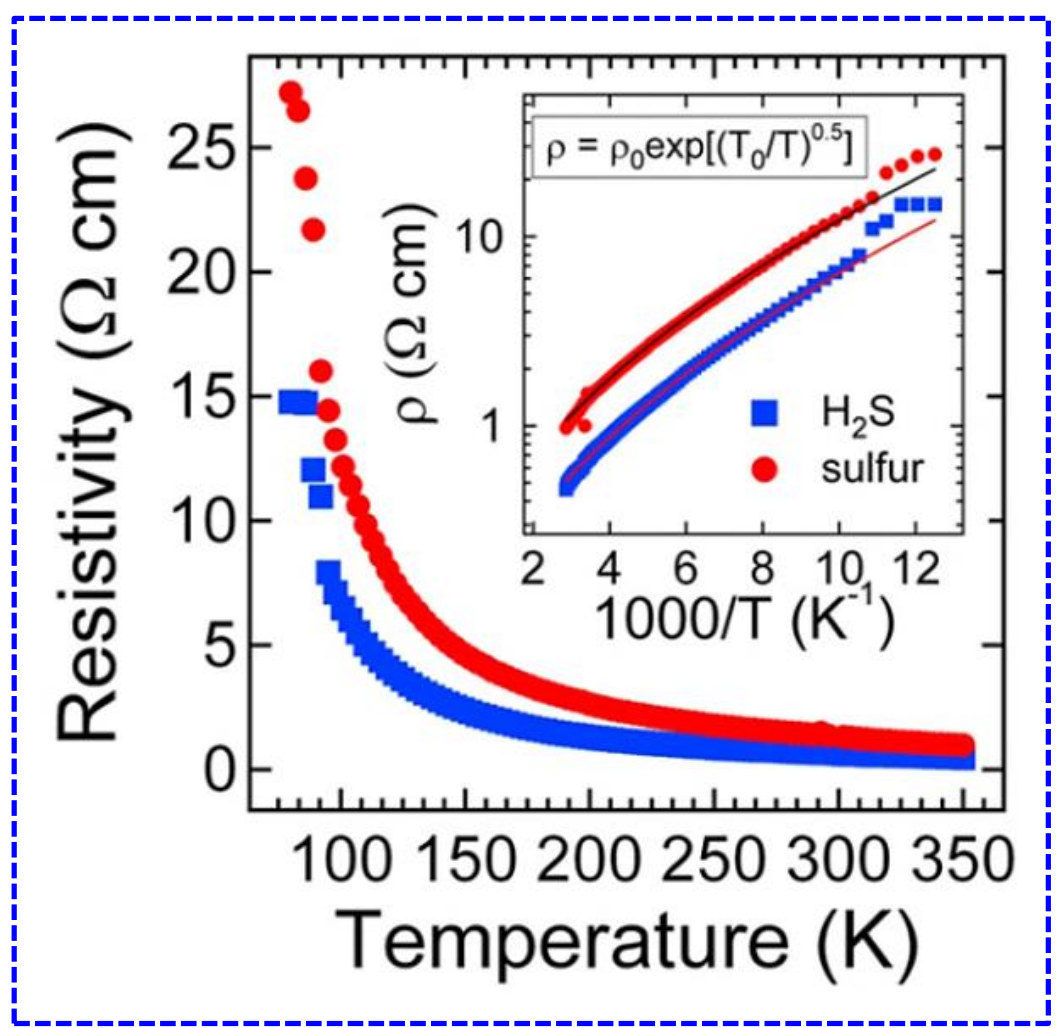

Figure 21. Electrical resistivity of pyrite and mixed-phase $\mathrm{FeS}_{2}$ films. Resistivity as a function of temperature $(80-350 \mathrm{~K})$ for representative $320 \mathrm{~nm}$ thick films on quartz substrates before sulfur annealing (blue squares) and after sulfur annealing (red circles). The room temperature resistivity of the two films is 0.64 and $1.35 \Omega \mathrm{cm}$, respectively. Inset is a $\log$-linear plot of the resistivity versus inverse temperature. The data are nonlinear and fit well to $\rho=\rho_{0} \exp \left[\left(\mathrm{T}_{0} / \mathrm{T}\right)^{\mathrm{a}}\right]$ with $\mathrm{a}=0.5 .{ }^{[230]}$ Reproduced with permission from ref. ${ }^{[230]}$. Copyright 2013 American Chemical Society.

Bhandari et al. ${ }^{[158]}$ calculated using equations barrier height for $p$-type films (carrier concentration; $\mathrm{n} \sim 1 \times 10^{19} \mathrm{~cm}^{-3}$, mobility; $\mu<1 \mathrm{~cm}^{-2} \mathrm{~V}^{-1} \mathrm{~s}^{-1}$ ) with different thickness as:

$\Phi=45-18 \mathrm{meV}$; thickness of $\mathrm{NC} \mathrm{Fe} S_{2}$ film $=486 \mathrm{~nm}$

$\Phi=51-20 \mathrm{meV}$; thickness of $\mathrm{NC} \mathrm{Fe} S_{2}$ film $=850 \mathrm{~nm}$

They found a good agreement between the Werner theory and the experimental results in the low temperature range of $300 \mathrm{~K}$ to $80 \mathrm{~K}$ although the standard deviation is relatively large 


\section{WILEY-VCH}

with work function values $3.3 \mathrm{eV}-3.5 \mathrm{eV}$. Similarly, thermoelectric properties of cobalt doped pyrite thin films were also observed to be influenced by temperature. ${ }^{[282]}$

\subsection{Marcasite and photovoltaic properties}

Kim et al. ${ }^{[283]}$ investigated the effect sulfurization temperatures $\left(350\right.$ and $\left.400{ }^{\circ} \mathrm{C}\right)$ on the phase transformation of marcasite to pure pyrite. The uniform grains with well-defined grain boundaries facilitate current along the grain boundaries. The impure pyrite thin films having marcasite-pyrite phases develop surface currents and a positively charged potential develops near the grain boundaries. The higher conductivity was observed in impure films due lower band gap of marcasite as compared to pure pyrite with larger current area. Pyrite thin film has a single work function peak at around $4.63 \mathrm{eV}$. The optical bandgaps of pure and impure pyrite films were estimated to be $0.86 \mathrm{eV}$ and $0.94 \mathrm{eV}$ with high refractive index of 3.2 at 0.5 $\mathrm{eV}$. They inferred the pure pyrite phase as better light absorber in solar cells. On the other hand, Wu et al. explored the beneficial role of marcasite in iron sulfide-based photoelectrochemical (PEC) applications. The pyrite-marcasite phase junctions showed dramatic improved photoresponse. The band alignment of $\mathrm{p} / \mathrm{m}-\mathrm{FeS} \mathrm{S}_{2}$ phase junctions at the phase boundary is shown in Figure 22. They observed enhanced charge separation and transfer across the $\mathrm{p} / \mathrm{m}-\mathrm{FeS}_{2}$ interface. Subsequently, the electrons movement to the pyrite phase resulted in the stability of more efficient pyrite-based PEC solar cells. ${ }^{[284]}$ Concisely, pyrite cannot simply be compared with and developed along the line of classical semiconductor compounds. More complementary research approach is required for improved photovoltaics properties of pyrite to scale up from lab to practical devices. 


\section{WILEY-VCH}

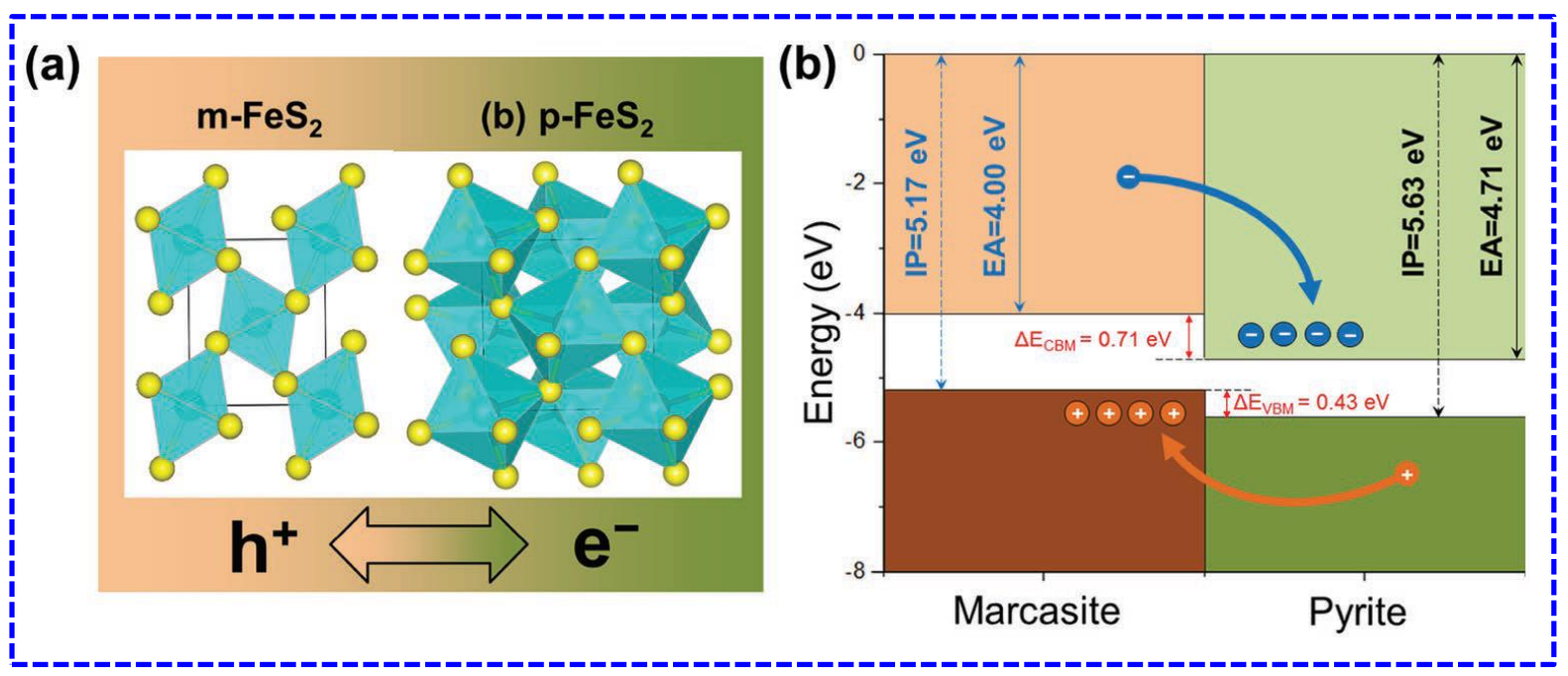

Figure 22. a) Structure of marcasite (left) and pyrite (right) in terms of $\mathrm{FeS}_{6}$ octahedra. b) Schematic of the band alignment between marcasite and pyrite. IP and EA denote ionization potential and electron affinity, respectively. The electron affinity is calculated by subtracting the band gaps from the calculated ionization potentials. $\triangle \mathrm{EVBM}$ and $\triangle \mathrm{ECBM}$ are the valence band offsets and conduction band offsets, respectively. ${ }^{[284]}$ Reproduced with permission from ref. ${ }^{[284]}$. Copyright 2016 John Wiley \& Sons.

Marcasite has a strong tendency to form simultaneously with pyrite, forming a mixed-phase structure in which pyrite crystals are surrounded by nanocrystalline marcasite boundaries. ${ }^{[280]}$ Optically, marcasite was found to have a bandgap of $0.85-0.88 \mathrm{eV}$, which is not as small as $0.4 \mathrm{eV}$ (a value frequently referred to as the bandgap of this phase) and only slightly smaller than the bandgap of pyrite $(0.96 \mathrm{eV})$ with a higher absorption coefficient than pyrite. Marcasite boundaries in the mixed film provided an efficient path for diffusion of photogenerated holes, leading to the higher photocurrent obtained for the mixed film than the photocurrent obtained for the phase-pure pyrite film in the photoelectrochemical measurement. These results suggest that it is strongly unlikely that the existence of marcasite in the pyrite matrix is the possible origin of the reportedly low or non-existent photovoltage of the state-ofthe-art pyrite-based solar cells. It is worth considering the application of phase-pure marcasite or a properly controlled marcasite/pyrite mixture as a new photoactive electrode material. 


\section{WILEY-VCH}

\section{Doped Pyrite for Photovoltaics}

Energy conversion efficiency of photovoltaic devices can be improved through engineering nanomaterials by introducing one or more energy levels within the bandgap. ${ }^{[285,286]}$ Quantum dot photovoltaic devices have revealed excellent external quantum efficiencies (EQEs) more than $100 \%$ because of multiple exciton generation (MEG) and quantum confinement effect. ${ }^{[287]}$ Large short-circuit current densities and strong photoactivity were observed by photoelectrochemical and solid-state Schottky pyrite devices. ${ }^{[37,288,289]}$ Nevertheless, low open-circuit voltage $\left(\mathrm{V}_{\mathrm{OC}}\right)$ of pyrite photovoltaic devices is still the main obstacle. Electrochemical, photoelectrochemical, optoelectronic and/ or spin properties of pyrite can be modified by alloying (substitutional doping) or by constructing $\mathrm{FeS}_{2}$ hybrid structures (composites). Obviously phase purity, stoichiometry and surface and interface chemistry of pyrite are of main concerns. ${ }^{[290]}$

Introducing dopant atoms into nanocrystals by synthetic control improve physical and chemical properties of materials by triggering energy levels at nano level. ${ }^{[291]}$ Substituting cations or anions with isovalent elements or compensated dimers is an extensively used methodology for tuning the band gaps of semiconductors. Recent advancement in nanotechnology has proved that nanostructured metal chalcogenides (MCs) are favourable nominees for efficient ECS systems based on their exceptional physical and chemical properties. ${ }^{[292]}$ Ternary metal chalcogenides systems have been widely applied in organic and inorganic p-n junctions as $\mathrm{TMS}_{2}$ such as $\mathrm{CuInS}_{2}, \mathrm{AgInS}_{2}, \mathrm{AgBiS}_{2}$ etc. thin films where they show improved properties ${ }^{[293]}$ than undoped metal sulfide thin films.

Sun et al. ${ }^{[44]}$ investigated alloying pyrite $\left(\mathrm{FeS}_{2}\right)$ for bandgap tuning by using density functional theory (DFT). Band gap of pyrite can be increased slightly by replacing some Fe by ruthenium $(\mathrm{Ru})$ or osmium (Os) to form $\mathrm{Fe}_{1-\mathrm{x}} \mathrm{Ru}_{\mathrm{x}} \mathrm{S}_{2}$ and $\mathrm{Fe}_{1-\mathrm{x}} \mathrm{Os}_{\mathrm{x}} \mathrm{S}_{2}$ compounds or by 


\section{WILEY-VCH}

alkaline earth metals elements $(\mathrm{Be}, \mathrm{Mg}, \mathrm{Ca}, \mathrm{Sr}, \mathrm{Ba})$ and $\mathrm{Cd} . \mathrm{Ru}$ and $\mathrm{Os}^{[32]}$ alloyed pyrite systems revealed bandgap enhancement practically but their incorporation into pyrite may be restricted by the large positive enthalpy of mixing. Recently, the first-principles calculations showed the increment in band gap of pyrite by alloying with oxygen $(\mathrm{O})$ or selenium $(\mathrm{Se}){ }^{[27]}$ Alongside they found bandgap narrowing by substitutional incorporation of zinc in $\mathrm{Z}_{\mathrm{x}} \mathrm{Fe}_{1-\mathrm{x}} \mathrm{S}_{2}$ alloys. ${ }^{[294]}$ Up till now, numerous dopants have been investigated $\left(\mathrm{Mn},{ }^{[295]} \mathrm{Co},{ }^{[296-298]} \mathrm{Ni},{ }^{[299]}\right.$ $\mathrm{Cu},{ }^{[300,301]} \mathrm{Zn},{ }^{[302]} \mathrm{Ti}^{[303]}{ }^{[3 e},{ }^{[304]} \mathrm{Sn},{ }^{[305]} \mathrm{Al}, \mathrm{P}, \mathrm{As},{ }^{[306]} \mathrm{Sb},{ }^{[307]} \mathrm{Cr}, \mathrm{Au},{ }^{[308]}, \mathrm{Ru},{ }^{[309]} \mathrm{Nd},{ }^{[310]}$ for modification and improvement of iron pyrite properties. $\mathrm{M}_{\mathrm{x}} \mathrm{Fe}_{1-\mathrm{x}} \mathrm{S}_{2}$ ternaries exhibit enhanced properties than $\mathrm{FeS}_{2}$, which can make the materials attractive as window material in heterojunction photovoltaic devices: pyrite organic, inorganic and hybrid solar cells. Recently, Mao et al. observed more than five times reduction of dark currents in the $\mathrm{Zn}_{\mathrm{x}} \mathrm{Fe}_{1-\mathrm{x}} \mathrm{S}_{2}$ photoconductor. $^{[147]}$

Lately, Cabán-Acevedo et al. ${ }^{[280]}$ carried out detailed investigation on $\{100\}$ - faceted n-type iron pyrite single crystals to explore its limited photovoltage and poor photoconversion efficiency and revealed that the ionization of high-density bulk deep donor states. These states may result from bulk/intrinsic sulfur vacancies that generate interrupted charge distribution and a very narrow surface space charge region thus limiting the total barrier height. Hence the literature suggests that the photovoltage/photocurrent and photoconversion efficiency of iron pyrite thin film solar cells can be improved by controlling and passivating bulk defects and intrinsic surface states. ${ }^{[311]}$

O'Brien and co-workers recently studied the properties of transition metal doped iron pyrite thin films $\left(\mathrm{M}_{x} \mathrm{Fe}_{1-x} \mathrm{~S}_{2}\right.$ where $\mathrm{M}=\mathrm{Co}, \mathrm{Ni}, \mathrm{Cu}$, or $\left.\mathrm{Zn}\right)$ deposited by aerosol-assisted chemical vapour deposition (AACVD) on various substrates including glass, (100) silicon and 


\section{WILEY-VCH}

indium tin oxide (ITO). The influence of transition metal doping on the structure (Figure 23) and phase transformation was significant in copper doped pyrite thin films. ${ }^{[221]}$

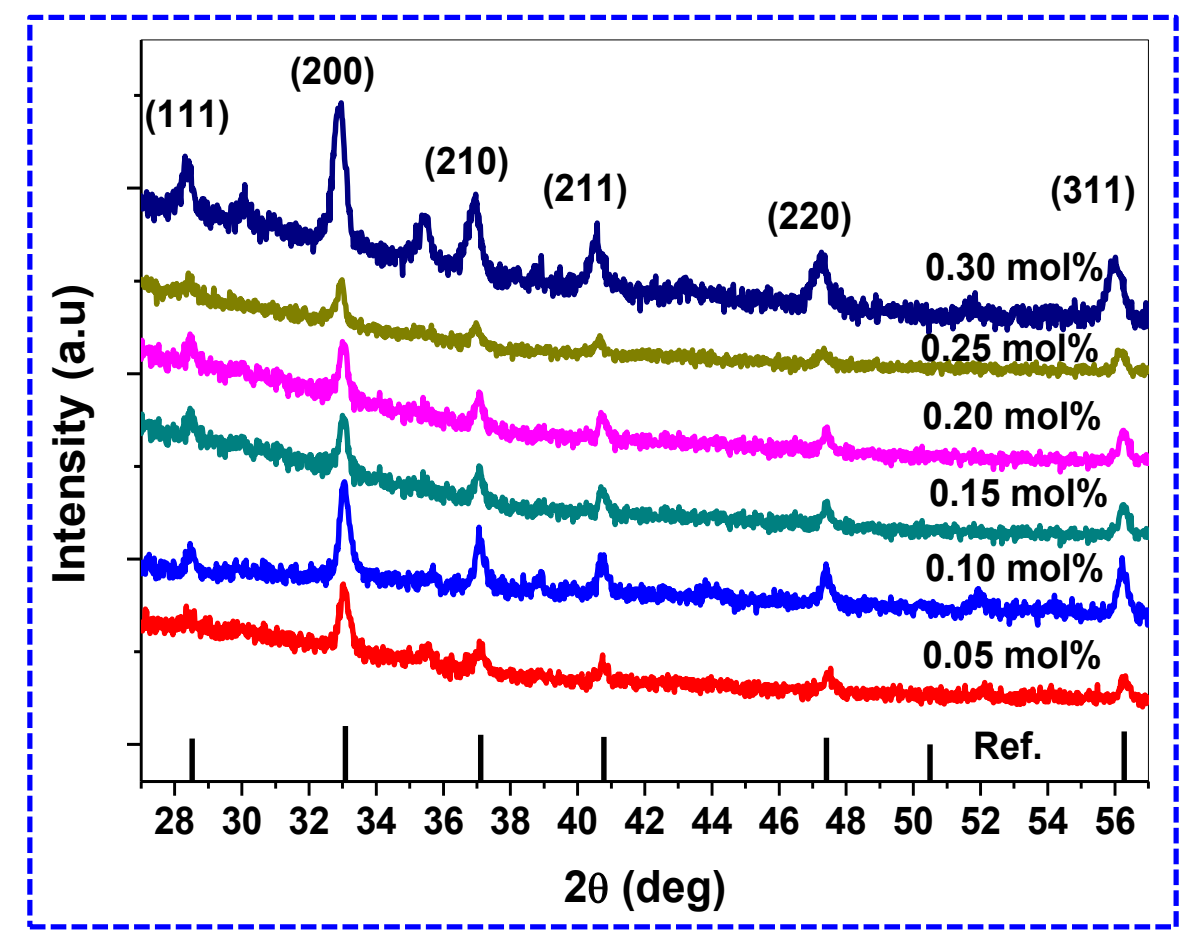

Figure 23. p-XRD patterns of cobalt doped iron sulfide $\mathrm{Co}_{x} \mathrm{Fe}_{1-x} \mathrm{~S}_{2}$ thin films deposited from complexes (1)and (2) at $350{ }^{\circ} \mathrm{C}$ on glass substrate synthesised by AACVD with different starting ratio of cobalt complex (2). ${ }^{[221]}$ Reproduced with permission from ref. ${ }^{[221]}$. Copyright 2015 Royal Society of Chemistry.

The height-profiling of $\mathrm{M}_{x} \mathrm{Fe}_{1-x} \mathrm{~S}_{2}$ films with atomic force microscopy (AFM) displayed average crystallite heights in the ranges $200-400 \mathrm{~nm}, 33-182 \mathrm{~nm}, 130-100 \mathrm{~nm}$ and $120-$ $140 \mathrm{~nm}$ with uniform distribution of particles. ${ }^{[221]}$ Optical studies revealed the increase in the bandgap of $\mathrm{M}_{x} \mathrm{Fe}_{1-x} \mathrm{~S}_{2}$ thin films by increasing the transition metal content. These findings can be further manipulated to improve doped pyrite layers for photovoltaic devices. ${ }^{[312]}$

\section{Recent trends: Pyrite Photovoltaics}

Although reported lab scale efficiency of pyrite base devices is not very high yet it has a potential for future pyrite solar cells; thanks to its suitable bandgap to sustain a photovoltage > $200 \mathrm{mV}$. Recent advances in nanotechnology have enabled the fabrication of economically 


\section{WILEY-VCH}

viable photovoltaic devices. Development of synthetic techniques to various nanostructured materials is potentially worthwhile in photovoltaic applications. In the last ten years, solution-processed (colloidal) pyrite thin films comprising nanocrystals have demonstrated excellent optoelectronic performance because of the quantum confinement effect summarized in a chapter by Alec et al. ${ }^{[313]}$ Mostly pyrite thin films show low majority carrier concentrations $\sim 10^{18} \mathrm{~cm}^{-3}$. Therefore pyrite thin film photovoltaic cells should be highly doped with carrier concentration of $10^{19} \mathrm{~cm}^{-3}$. Ferrer et $a l .{ }^{[314]}$ concluded by modelling that pyrite with $\mathrm{E}_{\mathrm{g}}=1.0 \mathrm{eV}$ based thin film solar cell can have $\mathrm{V}_{\mathrm{OC}}$ of the order of $500 \mathrm{mV}$ with efficiencies 20\% (Figure 24).

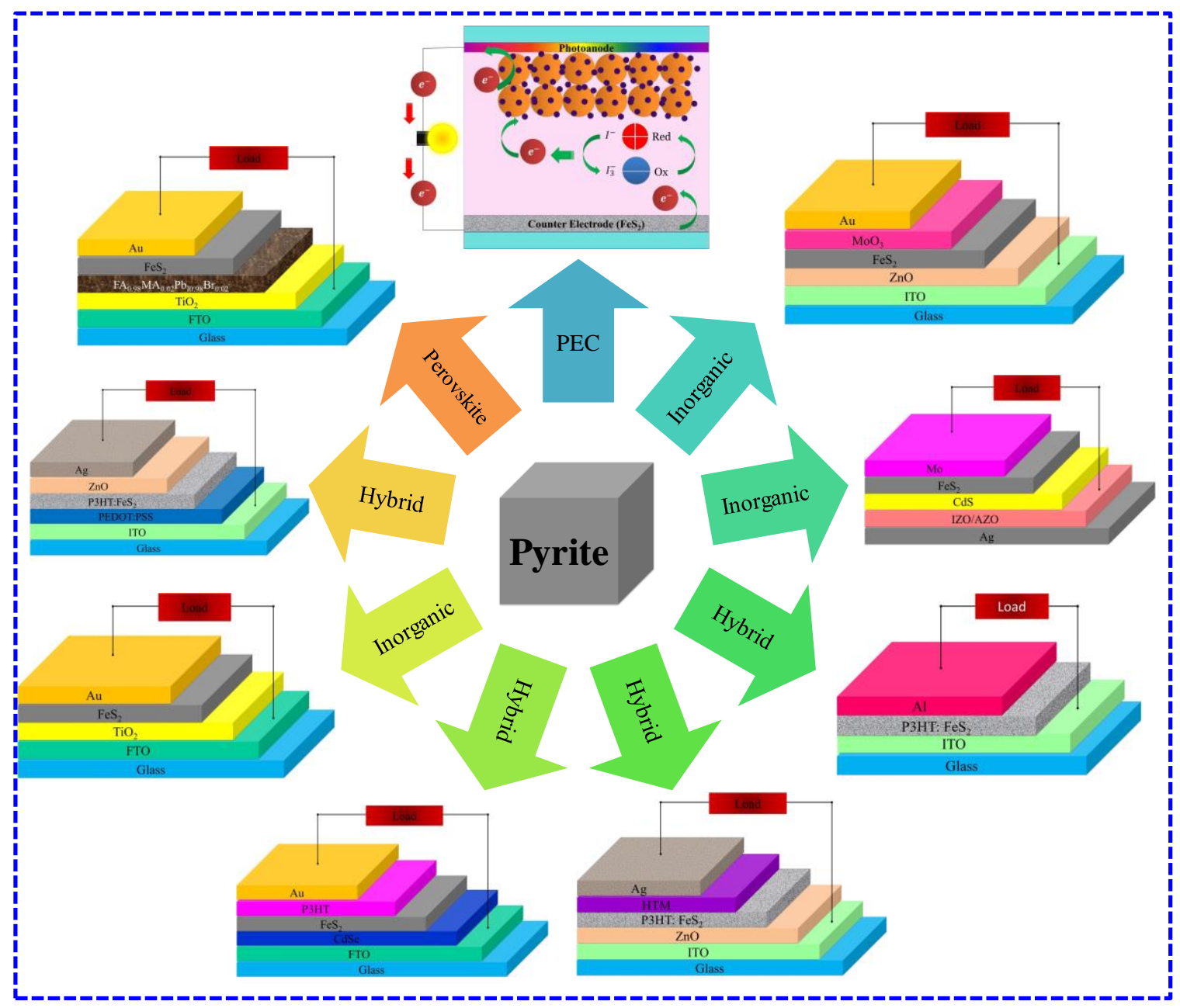

Figure 24. Schematic representation of the various configurations of solar cells containing $\mathrm{FeS}_{2}$ layers 


\section{WILEY-VCH}

\subsection{As absorber layer}

Limpinsel et al. ${ }^{[315]}$ investigated pn-heterojunctions thin film solar cell with configuration: glass/Mo/ $\mathrm{MoS}_{2} / \mathrm{FeS}_{2} / \mathrm{ZnS} / \mathrm{ZnO} / \mathrm{AZO}$ where $\mathrm{Al}$-doped $\mathrm{ZnO}$ (AZO) as top contact, $\mathrm{Mo} / \mathrm{MoS}_{2}$ bilayer ((typically $\sim 1500 \mathrm{~nm})$ ) as back contact, ZnO \& n-type cubic $\mathrm{ZnS}$ as window layer and p-type $\mathrm{FeS}_{2}$ as absorber layer. Open circuit voltage of $410 \mathrm{meV}$ (610 meV after aging in air) and short-circuit current of $5 \mu \mathrm{A} / \mathrm{cm}^{2}$ under AM1.5G radiations at power of $50 \mathrm{~mW} / \mathrm{cm}^{2}$ using intense halogen light $\left(30 \mu \mathrm{A} / \mathrm{cm}^{2}\right)$ were obtained. Cubic $\mathrm{ZnS}$ was the favourable candidate as window layer with $\mathrm{FeS}_{2}$ that displayed rectifying pn-junctions. Higher values of photovoltage or $\mathrm{V}_{\mathrm{OC}}$ require low reverse current (photocurrent) and larger photocurrent densities $\mathrm{J}_{\mathrm{SC}}$ require high forward current. Low photocurrent was generated by high-energy photons was attributed to high surface recombination velocities or a conduction band offset to $\mathrm{ZnS}$ as open-circuit photovoltage depends on band alignment of junction.

\subsection{As counter electrode}

Dye-sensitized solar cells (DSSCs) have attracted great interest for the fabrication of low-cost large area photovoltaic devices as an alternative to conventional inorganic solar cells. ${ }^{[316]} \mathrm{A}$ typical DSSC consists of the working electrode (semiconductor-photoanode) to activate electronic conduction, dye to enhance light absorption, electrolyte solution with a redox mediator effecting dye-regenerating, and the counter electrode (noble metal, graphene typically platinum $(\mathrm{Pt})$ ) to facilitate electron collection. Although Pt has excellent capability for catalyzing the $\mathrm{I}^{-}$regeneration from the $\mathrm{I}_{3}{ }^{-}$species in the redox couple yet its high cost and rarity affirm interest in exploring platinum free counter electrodes for DSSCs. ${ }^{[317]}$

Wang et al. ${ }^{[318]}$ demonstrated the DSSC device with the low cost CE using the solution-processable and semi-transparent $\mathrm{FeS}_{2} \mathrm{NC}$ thin film (thickness $=100 \mathrm{~nm}$ ) exhibits promising power conversion efficiency of $7.31 \%$ comparable to that of Pt-CE (7.52\%). $\mathrm{FeS}_{2}$ 


\section{WILEY-VCH}

NC also exhibits significant electrochemical stability of greater than 500 consecutive cycle scans. Solution-processable $\mathrm{FeS}_{2} \mathrm{NC}$ ink can be printed onto various substrates such as ITO/PET (Indium tin oxide coated polyethylene terephthalate substrate) and FTO (fluorine doped tin oxide glass substrate) which are heat sensitive or flexible for large-area roll-to-roll

production. ${ }^{[318]}$ Recently Wei et al. ${ }^{[120]}$ demonstrated $\mathrm{FeS}_{2}$ nanochain networks as efficient CE with high power conversion (6.26\% on PET-ITO substrate and 7.16\% on FTO substrate) for DSSCs. As-prepared pyrite nanochain network exhibited high catalytic activity with no significant decay even after 2000 cycles.

To reduce degradation effects and low efficiency of DSSCs, the tandem DSSCs could be attractive devices for the improved power conversion efficiency of solar modules. In tandem dye sensitized solar cells Pt cathode is replaced by photocathode to absorb more solar energy. ${ }^{[319,320]}$ The fill factor $(F F)^{[321]}$ and photovoltaic efficiency $(\eta)^{[322]}$ are given by following equations $(25,26)$ :

$$
\begin{gathered}
F F=\frac{I_{\max } V_{\max }}{I_{S C} V_{O C}} \\
\eta(\%)=\frac{I_{\max } V_{\max }}{P_{h}}
\end{gathered}
$$

where $\boldsymbol{I}_{\max }$ and $\boldsymbol{V}_{\text {max }}$ are current and voltage at maximum power point on the power output curve and $\boldsymbol{I}_{\boldsymbol{S C}}$ is short circuit current, $\boldsymbol{V}_{\boldsymbol{O} \boldsymbol{C}}$ is open circuit voltage and $\boldsymbol{P}_{\boldsymbol{h}}$ is the power density of incident light. The counter electrode of $\mathrm{FeS}_{2}$ nanorod arrays synthesized on FTO substrate by sulfurizing precursor nanorods of $\mathrm{FeO}(\mathrm{OH})$ showed excellent power conversion efficiency than the $\mathrm{FeS}_{2}$ film and Pt film due to their active facets and lower interface resistance as tested for DSSCs. It helps to achieve a high short-circuit photocurrent density (Jsc) of DSSCs. ${ }^{[323]}$ Recently, $\mathrm{FeS}_{2}$ thin films (200 $\pm 50 \mathrm{~nm}$ thickness) were prepared by sulfuration $\left(400{ }^{\circ} \mathrm{C}\right.$ for 30 minutes) of pre-deposited films. The precursor films were fabricated by spray pyrolysis of 


\section{WILEY-VCH}

$\mathrm{FeCl}_{3} \cdot 6 \mathrm{H}_{2} \mathrm{O}$ and $\left(\mathrm{NH}_{2}\right)_{2} \mathrm{CS}$ on glass substrate in ratio (1:6) of iron and sulfur precursors. The $\mathrm{FeS}_{2}$ films displayed comparable photoconversion efficiency $(8.0 \%)$ to $\mathrm{Pt}(7.5 \%)$ in $\mathrm{I}_{3} / \mathrm{I}$ while efficiency of $\mathrm{FeS}_{2}$ and PEDOT (poly(3,4-ethylenedioxythiophene)) was found to be same 6.3 $\%$ in $\mathrm{Co}(\mathrm{III}) / \mathrm{Co}(\mathrm{II})$ electrolytes (Figure 25). ${ }^{[324]}$

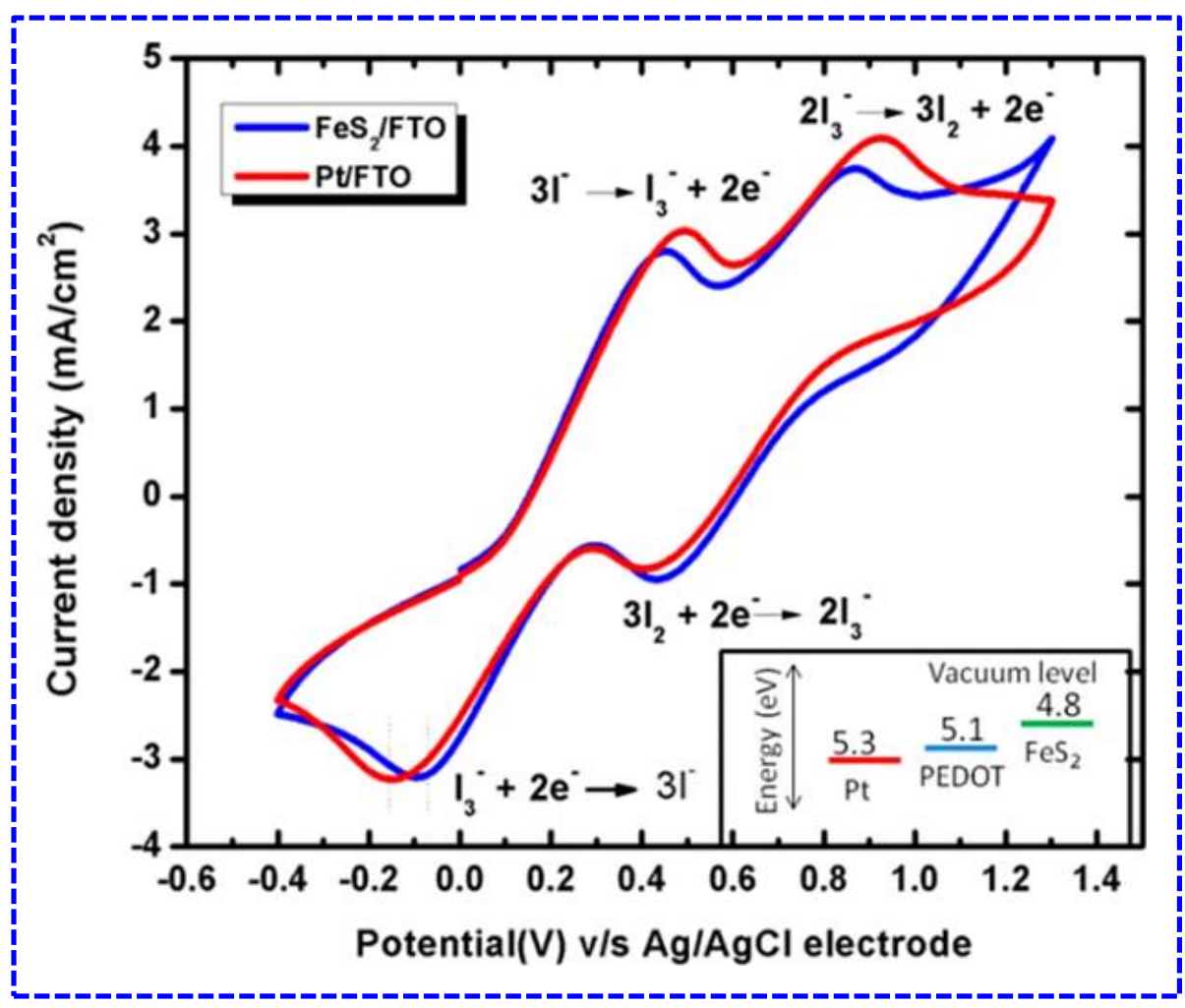

Figure 25. Cyclic voltammetry of $\mathrm{FeS}_{2}$ and $\mathrm{Pt}$ electrodes with an iodine/tri-iodide redox electrolyte. Inset: work function of Pt, PEDOT, and $\mathrm{FeS}_{2} \cdot{ }^{[324]}$ Reproduced with permission from ref. ${ }^{[324]}$. Copyright 2014 American Chemical Society.

A tandem device structure is a practical way to enhance the efficiency of solar cell by harvesting a wider spectrum of solar radiations. $\mathrm{TiO}_{2}-\mathrm{FeS}_{2}$ tandem solar cell with thin n-type $\mathrm{FeS}_{2}$ nanosheets (thicknesses 30-50 $\mathrm{nm}$ and flower-like morphology) as photocathode and $\mathrm{n}$ type $\mathrm{TiO}_{2}$ nanorod film as the photoanode was investigated by $\mathrm{Hu}$ et al. The photovoltaic parameters were calculated using above equations are $I_{S C}=2.04 \frac{\mathrm{mA}}{\mathrm{cm}^{2}}, V_{O C}=0.38 \mathrm{~V}$, $F F=0.40, \eta=0.93 \%$ for $\mathrm{TiO}_{2}-\mathrm{FeS}_{2}$ tandem DSSC. ${ }^{[131]}$ 


\section{WILEY-VCH}

Recently, Batmunkh et al. ${ }^{[325]}$ investigated sulfur doped graphene with $\mathrm{FeS}_{2}$ microspheres $\left(\mathrm{SGN}-\mathrm{FeS}_{2}\right)$ based hybrid electrocatalysts as a counter electrode alternative to platinum in DSSCs. The bifunctional hybrid electrocatalyst-based device displayed power conversion efficiency (PCE) of $8.1 \%$ comparable to $8.3 \%$ of traditional Pt CE-based DSSC, while also exhibiting excellent stability in ambient conditions.

Similarly, Kilic et al. observed the increased the power conversion efficiency from $1.56 \%$ to $3.14 \%$ in graphene/copper oxide urchin-like nanostructures (thickness around 30 $\mu \mathrm{m})$ as photocathode and $\mathrm{PtFeS}_{2}$ (cubic-shaped nanostructures about 20-40 nm) as CE in ptype DSSCs. High catalytic activity of $\mathrm{FeS}_{2} \mathrm{CE}$ due to large effective surface area leaded to low-charge transfer resistance. The graphene/copper oxide urchin-like nanostructures exhibited an enhancement of photon-to-current conversion efficiency (IPCE). IPCE shifted upward in DSSCs in presence of $\mathrm{FeS}_{2} \mathrm{CE}$ as compared to Pt CE. The overall improved results were attributed to the synergetic combination of electrodes. ${ }^{[326]}$

\subsection{Pyrite as quantum dot inorganic semiconducting dye}

Recent trend in development of DSSCs is environment friendly green quantum dot dye sensitized solar cell (QDSSC). The only physical difference between the DSSC and (QDSSC) is the quantum dot inorganic semiconducting dye. ${ }^{[327]}$ Modifications in the physical dimensions of the inorganic semiconductor nanoparticle changes band gap, as compared to the band gap of bulk semiconductors due to quantum confinement effect. ${ }^{[328]}$ Inorganic semiconductors have been considered as ideal next-generation sensitizers to overcome the limited DSSCs efficiency. By engineering quantum-dot size, high absorption coefficient, high carrier mobilities and multiple carrier generation can together play a role for exceeding the

Schottkye-Queisser limit. ${ }^{[329]}$ Surface modification of $\mathrm{TiO}_{2}$ with $\mathrm{FeS}_{2}$ quantum dots for 


\section{WILEY-VCH}

photoelectrochemical cell yielded maximum incident photon-to-photocurrent efficiency (IPCE) about $23 \%$ at $400 \mathrm{~nm}$ excitation determined from the equation (27): ${ }^{[330]}$

$$
\operatorname{IPCE}(\%)=100 \cdot \frac{1240 I_{S C}}{I_{\text {inc }} \lambda}
$$

where $\mathrm{I}_{\mathrm{sc}}$ is the short-circuit current $\left(\mathrm{A} / \mathrm{cm}^{2}\right), \mathrm{I}_{\mathrm{inc}}$ is the incident light intensity $\left(\mathrm{W} / \mathrm{cm}^{2}\right)$, and $\lambda$ is the excitation wavelength (nanometers).

The photocurrent and open-circuit potential measurements under the AM 1.5 light illumination revealed high light-harvesting efficiency of ca. $3.8 \mathrm{wt} \%$ pyrite $\left(\mathrm{FeS}_{2}\right)$ sensitized titania $\left(\mathrm{TiO}_{2}\right)$ nanotube (NT) arrays. The inner diameter of titania nanotubes (TNTs) was ca. $100 \mathrm{~nm}$ and the wall thickness was ca. $15 \mathrm{~nm}^{[331]}$ The pyrite is found to be an effective sensitizer for titania nanotube arrays to assist the photodegradation of rhodamine B in water under solar light illumination following the pseudo-first order reaction (28).

$$
\ln \frac{c_{o}}{c}=k t
$$

where is $c_{o} / c$ the normalized rhodamine $\mathrm{B}$ concentration, $t$ is the illumination time, and $k$ is the apparent reaction rate in terms of time $\min ^{-1}$.

A blue shift was observed in absorption edge of $\mathrm{TiO}_{2}(20 \mathrm{~nm}), \mathrm{ZnO}$ nanoparticulate (diameter 2-5 nm), and $\mathrm{ZnO}$-nanorod ( $8 \mu \mathrm{m}$ in length and $300 \mathrm{~nm}$ in diameter) electrodes sensitized with $\mathrm{FeS}_{2}$ (pyrite) nanoparticles $(50-70 \mathrm{~nm})$. Quantum size effect is manifested in both absorption (band gap 1.6 -2.0 eV) and photocurrent action spectra. The photoinduced absorption (PIA) spectra indicate long-live charge separated state occurring in the quantum dot sensitized metal oxides. Highest long-live charge separation was observed for $\mathrm{FeS}_{2}$ modified $\mathrm{ZnO}$ nanorods. However multiphase $\mathrm{FeS}_{2}$ affects performance of the electrodes so there is need to develop phase pure and stoichiometric pyrite for promising quantum dot solar cells. ${ }^{[332]}$ 


\section{WILEY-VCH}

A dispersion of $\mathrm{FeS}_{2} \mathrm{NCs}$ (nanocubes of size $80 \pm 5 \mathrm{~nm}$ and quantum dots of size $15 \pm 3$ $\mathrm{nm}$ ) in CdS QDs (4 nm) matrix showed stronger interfacial interaction between $\mathrm{FeS}_{2} \mathrm{NCs}$ and CdS QDs due to the formation of continuous donor/acceptor phases at interface. In the bulk heterojunction solar cell (BHJ) photoactive film, layer-by-layer and sequential ligand exchange treatment can greatly enhance charge separation and transport efficiency, which is essential for all inorganic BHJ solar cells in comparison to the $\mathrm{FeS}_{2} / \mathrm{CdS}$ bi-layer heterostructures. The BHJ device comprising $\mathrm{FeS}_{2} / \mathrm{CdS}$ heterostructures showed open circuit voltage, $\mathrm{V}_{\mathrm{OC}}=0.79 \mathrm{~V}$ and power conversion efficiency, $\rho=1.1 \%$ under AM 1.5 solar illumination. Amplified charge separation efficiency and the enhanced charge collection efficiency is facilitated by the bicontinuous percolated nanomorphology that provides more effective transport pathways for both electrons and holes. ${ }^{[333]}$

The BHJ device (ITO/PEDOT:PSS/P3HT:PCBM:FeS 2 QDs/Al) loaded with $20 \mathrm{wt} \%$ of $\mathrm{FeS}_{2}$ QDs $(5 \mathrm{~nm})$ revealed an improved conversion efficiency of $3.62 \%\left(\mathrm{~J}_{\mathrm{SC}}=16.31 \mathrm{~mA} / \mathrm{cm}^{2}\right.$, $\left.\mathrm{V}_{\mathrm{OC}}=0.58, \mathrm{FF}=56 \%\right)$ from the normal BHJ device efficiency of $2.32 \%\left(\mathrm{~J}_{\mathrm{SC}}=8.1 \mathrm{~mA} / \mathrm{cm}^{2}\right.$, $\left.\mathrm{V}_{\mathrm{OC}}=0.60, \mathrm{FF}=41 \%\right) .{ }^{[149]}$ The external quantum efficiency $48 \%$ attributed to the effect of QDs addition leading to strong visible $(800 \mathrm{~nm})$ and infrared light $(900 \mathrm{~nm})$ absorption and fast and balanced electronic mobility due to inorganic nature of quantum dots photoactive $\mathrm{FeS}_{2}$ layer. ${ }^{[149]}$

\subsection{Pyrite as hole transport layer}

Organic-inorganic hybrid solar cells combine organic (normally conjugated polymers-electron donor) and inorganic nanoparticles $\left(\mathrm{TiO}_{2}, \mathrm{ZnO}\right.$ and $\mathrm{CdSe}$-electron accepters). Power conversion efficiencies (PCE) beyond 3\% have been reported for polymer-inorganic hybrid solar cells. ${ }^{[334]}$ A typical bulk heterojunction (BHJ) solar cell consists of conjugated polymers (poly-3-hexyl thiophene (P3HT), phenyl- $\mathrm{C}_{61}$-butyric acid methyl ester (PCBM) etc.) 


\section{WILEY-VCH}

incorporated with semiconductor nanocrystals $\left(\mathrm{TiO}_{2}, \mathrm{ZnO}, \mathrm{PbS}, \mathrm{CdS}\right.$ etc. $)$ sandwiched between a transparent metal oxide electrode, generally, indium tin oxide (ITO) and a low work function metal, generally, aluminium (Al). ${ }^{[335]}$ Lin et al. ${ }^{[232]}$ investigated hybrid solar cell based on pyrite nanocrystals $(10 \mathrm{~nm})$. Thickness of active $\mathrm{P} 3 \mathrm{HT} / \mathrm{FeS}_{2} \mathrm{NC}$ hybrid layer was $80-100 \mathrm{~nm}$ with device area $0.05 \mathrm{~cm}^{2}$. Absorption edge shifted from $650 \mathrm{~nm}$ to $900 \mathrm{~nm}$ as compared to pristine P3HT. A high photoresponse with PCE $0.16 \%$ was observed in this polymer based pyrite solar cell. ${ }^{[232]}$

Buffer layer of acidic PEDOT:PSS (Poly(3,4-ethylenedioxythiophene : Polystyrene sulfonate) layer proves to be unfavourable to active polymer layer P3HT:PCBM (poly-3hexyl thiophene : phenyl-C61-butyric acid methyl ester), and oxidation and degradation of the low work function metal cathode (Al) are the major instability problem of organic solar cells (OSCs). ${ }^{[336]}$ It is dynamically more favourable to contact such a layer to a less air sensitive metal such as Ag or Au. ${ }^{[337]}$ Inverted organic solar cells structure was discovered to overcome above deficiencies. Inverted organic solar cells consist of high work function metal or metal oxide as the top electrode and low work function metal as the bottom anode. This inverted configuration has improved OSCs's life time by controlling oxidation of the top electrode with an impressive PCE of $4.4 \% .^{[338]}$

Hole transport layer blocks electrons and extracts holes efficiently. Consequently improves device performance by enhancing open circuit voltage. $\mathrm{FeS}_{2}$ nanocrystals with an average radius of $27 \mathrm{~nm}$ (concentration varied from 0 to $\sim 4 \mathrm{wt} \%$ ) were utilized to form inverted ternary hybrid BHJ solar. Photocurrent enhancement up to $20 \%$ was observed by adding $\mathrm{FeS}_{2} \mathrm{NCs}$ up to $\sim 0.5 \mathrm{wt} \%$ in the films. Pyrite NCs enhance the film morphology increasing charge generation and transport. Fill factor, open-circuit voltage and PCE up to 


\section{WILEY-VCH}

$28 \%$ enhanced after 28 days exposure of these hybrid devices to air compared to the control device with no $\mathrm{FeS}_{2}{ }^{[339]}$

Nickel doped pyrite thin films $\left(\mathrm{Ni}_{\mathrm{x}} \mathrm{Fe}_{1-\mathrm{x}} \mathrm{S}_{2}\right) \mathrm{NCs}(\mathrm{x}=0$ to 0.1$)$ have been applied as the hole transport layer (HTL) in the CdS/CdTe solar cells. $\mathrm{Ni}_{0.05} \mathrm{Fe}_{0.95} \mathrm{~S}_{2}$ NC-based HTL improved the CdS/CdTe device efficiency by $\sim 5 \%$ and it may play a significant role in energy harvesting applications (Figure 26). ${ }^{[340]}$

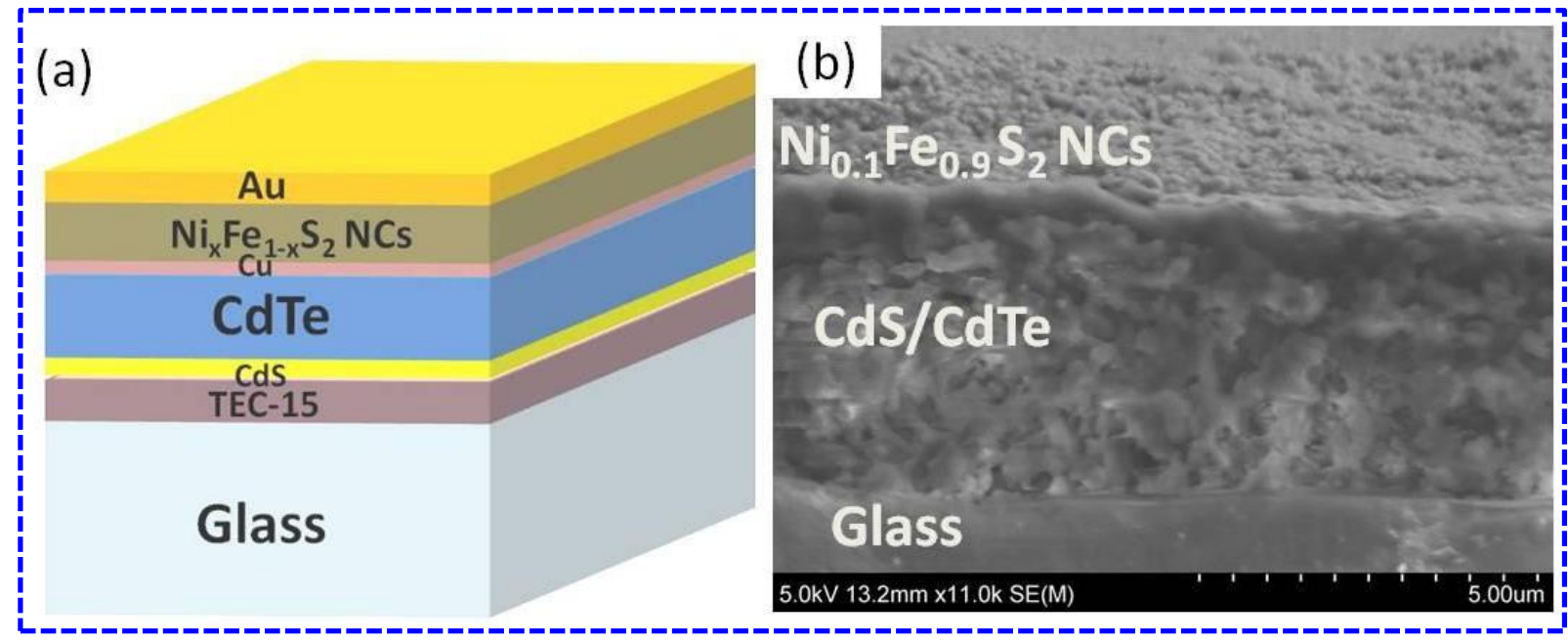

Figure 26. Device structure of CdTe solar cell using $\mathrm{Ni}_{x} \mathrm{Fe}_{1-x} \mathrm{~S}_{2}$ as back contact material (a) schematic diagram of the device structure (b) cross-sectional SEM image of CdS/CdTe solar cells with $\mathrm{Ni}_{0.1} \mathrm{Fe}_{0.9} \mathrm{~S}_{2}$ NCs as interface layer. ${ }^{[340]}$ Reproduced with permission from ref. ${ }^{[340]}$. Copyright 2017 Royal Society of Chemistry.

Bhandari et al. demonstrated that the $\mathrm{FeS}_{2}$ thin film inclusion in $\mathrm{CdS} / \mathrm{CdTe}$ solar cells as a hole transport layer improved $\mathrm{V}_{\mathrm{OC}}$ by $2.1 \%(817 \mathrm{mV})$ and $\mathrm{FF}$ by $8.3 \%$ relative $(74.7 \%)$ as compared to $\mathrm{CdS} / \mathrm{CdTe}$ devices without $\mathrm{FeS}_{2}$ layer. CdS/CdTe devices with $\mathrm{FeS}_{2}$ layer at 100 $\mathrm{mA} / \mathrm{cm}^{2}$ simulated AM1.5G and $25^{\circ} \mathrm{C}$ showed a conversion efficiency $\eta$ as high as $13.3 \%$ - a relative increase in $\eta$ of $\sim 10 \%$ over our current laboratory standard back contact. ${ }^{[341]}$

\subsection{Pyrite as electron acceptor layer}

Photogenerated excitons are dissociated efficiently at the bulk-heterojunction interface of P3HT:FeS ${ }_{2}$ hybrid, displaying the favourable role of electrons acceptor of $\mathrm{FeS}_{2}$ QDs 


\section{WILEY-VCH}

inorganic/inorganic hybrid solar cells. The mercaptopropanoic acid (MPA) treated hybrid thin film enables further improvement in solar cell performance compared to pyridine exchange because of suppressed reverse dark current as well as increased charge collection. ${ }^{[342]}$

Steinhagen et al. ${ }^{[138]}$ has explored various device architectures for pyrite nanocrystals, including Schottky junction, heterojunction, and hybrid organic/nanocrystal devices. But none of the devices exhibited photovoltaic response that appears to derive from the highly conductive surface-related defects in pyrite. ${ }^{[343,344]}$ Wang et al. ${ }^{[345]}$ demonstrated a photodiode device based on pyrite $\mathrm{FeS}_{2} \mathrm{NCs} /$ metal oxide heterojunctions with a ITO/ $\mathrm{ZnO}(80 \mathrm{~nm}) / \mathrm{FeS}_{2}$ $\mathrm{NC}(100 \mathrm{~nm}) / \mathrm{MoO}_{3}(15 \mathrm{~nm}) / \mathrm{Au}$ structure. Excellent photoresponse with a high photocurrent/dark current ratio, and spectral response ranging from visible to NIR wavelengths of up to $1150 \mathrm{~nm}$ of solution processable $\mathrm{FeS}_{2} \mathrm{NCs}$ offers extensive potential for development of photovoltaic industry.

Possible pyrite formation pathways are still to be explored via low temperature synthetic procedures. The performance of iron pyrite solar cell can be improved by blocking the fast carrier localization process originating from the intrinsic defects (such as sulfur vacancies). Shukla et al. presented photocarrier generation and relaxation model by comprehensive analysis that explains the rapid carrier relaxation before collection. ${ }^{[346]}$

Parabukanthan et al. demonstrated 3 mole $\% \mathrm{Co}^{2+}$ doped $\mathrm{FeS}_{2}$ nanocrystalline thin film showed improved physicochemical properties. The solar cell device structure ITO/3 mole\% $\mathrm{Co}-\mathrm{FeS}_{2} / \mathrm{ZnSe} / \mathrm{Au}$ exhibited the JSC $=10.71\left(\mathrm{~mA} / \mathrm{cm}^{2}\right), \mathrm{V}_{\mathrm{OC}}=0.83 \mathrm{~V}, \mathrm{FF}=0.61 \%$ and PCE $=5.42 \%$ with power intensity $100 \mathrm{~mW} / \mathrm{cm}^{2} \cdot[347]$

Surface optimization is key perspective for improvement of pyrite thin film based solar cells. Primarily, surface/interface effects such as inversion layer at the surface and deep donor defect states in the bulk determine the transport properties of polycrystalline pyrite 


\section{WILEY-VCH}

films and hence the properties of the photovoltaic device. The structural defects at interface can increase trap-assisted surface recombination resulting in low open circuit voltage of the photovoltaic device. The trap density can be decreased by surface functionalization, passivation and post annealing. ${ }^{[21,267,348,349]}$ In short, rational device design and appropriate band alignment between $\mathrm{FeS}_{2}$ and various materials (Figure 27) can improve the efficiency of the device e.g., inverted architecture of BHJ solar cells can also help reduce leakage current and prevent shorting in hybrid devices.

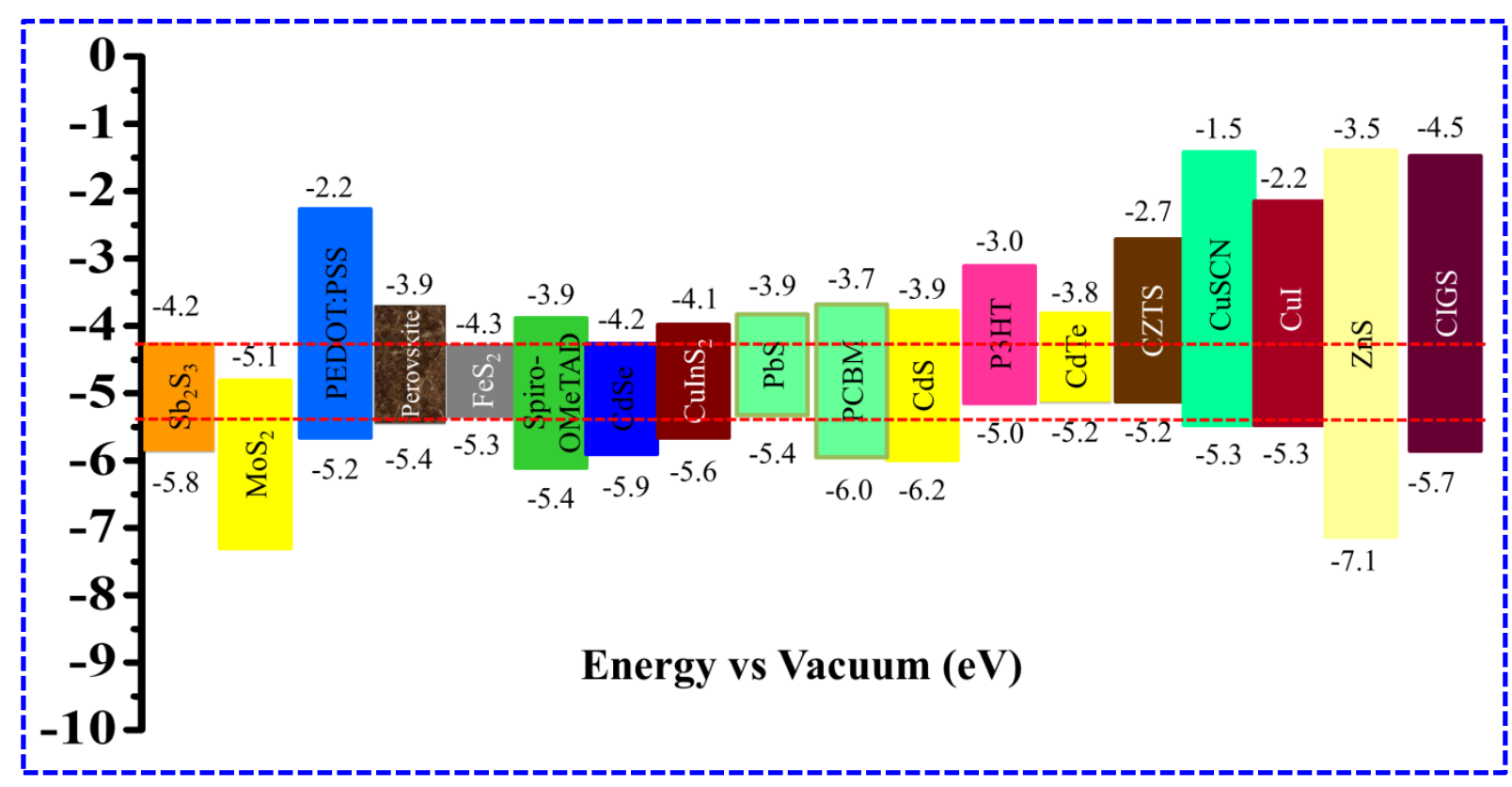

Figure 27. Schematic representation of energy level alignment between $\mathrm{FeS}_{2}$ and various materials.

Recently, Zhang et al. ${ }^{[350]}$ revealed three main findings about behaviour of conductivity in pyrite: (i) $n$-type conductivity in both crystals and thin films with the highest mobility was observed by Hall effect and thermo-power measurements. (ii) The mobility decreased followed by an apparent crossover from $n$ to $p$ type that can be attributed to crossover from diffusive to hopping transport. (iii) Both crystals and films showed a universal behaviour of $n$ dopant possibly due to sulfur vacancies. 


\section{WILEY-VCH}

Succinctly, all problems associated with pyrite should be solved to harvest sunlight efficiently. Many issues can be resolved by doping, alloying or combining properties of pyrite with other systems forming composites. Synthesis of pyrite at nanoscale also offers great opportunity for tuning its properties so that sustainable, scalable and commercialized pyrite based photovoltaic devices can endeavours their services for mankind. 
Table 4. Summary of pyrite photovoltaics $\uparrow$

\begin{tabular}{|c|c|c|c|c|c|c|c|c|}
\hline $\begin{array}{l}\text { Sr. } \\
\#\end{array}$ & Layers configuration & $\begin{array}{l}\mathrm{FeS}_{2} \\
\text { Layer } \\
(\mathrm{nm})\end{array}$ & $\begin{array}{l}\text { Irradiatio } \\
\text { n Light }\end{array}$ & $\begin{array}{l}\mathbf{I}_{\mathrm{SC}} \text { or } \mathbf{J}_{\mathrm{SC}} \\
\left(\mathrm{mA} / \mathbf{c m}^{2}\right)\end{array}$ & $\mathbf{V}_{\text {oC }}(\mathbf{V})$ & FF & Efficiency $(\%)$ & Ref. \\
\hline 1 & $\mathrm{ITO} / \mathrm{FeS}_{2} \mathrm{NCs} / \mathrm{Al}$ & 400 & AM1.5 & - & - & - & - & [194] \\
\hline 2 & ITO/P3HT:PCBM:FeS 2 NCs/Al & 100 & AM1.5 & $6.69-7.63$ & 0.66 & $47 \%$ & 2.30 (PCE) & [351] \\
\hline \multirow[t]{4}{*}{3} & $\mathrm{Au} / \mathrm{FeS}_{2} \mathrm{NC} / \mathrm{Al}$ & 2500 & AM1.5 & - & - & - & - & {$[138]$} \\
\hline & $\mathrm{Au} / \mathrm{FeS}_{2} \mathrm{NC} / \mathrm{CdS} / \mathrm{ZnO} / \mathrm{ITO}$ & & AM1.5 & 0.03 & $11 \mathrm{mV}$ & 0.174 & 0 & [138] \\
\hline & $\mathrm{TiO}_{2} / \mathrm{FeS}_{2} \mathrm{NC} / \mathrm{Au}$ & & AM1.5 & - & - & - & 0 & {$[138]$} \\
\hline & PEDOT:PSS/P3HT:FeS $2 / \mathrm{Al}$ & & AM1.5 & 0.007 & $41 \mathrm{mV}$ & 0.25 & 0 & {$[138]$} \\
\hline 3 & $\mathrm{FeS}_{2}$ nanoplates/P3HT & 140 & AM1.5 & - & 0.78 & & 0.03 (PCE) & [140] \\
\hline \multirow[t]{3}{*}{4} & $\mathrm{FeS}_{2} / \mathrm{CdS}$ & 500 & $\mathrm{AM} 1.5$ & 0.02 & & & 0.00025 (PCE) & [333] \\
\hline & $\mathrm{FeS}_{2} / \mathrm{CdS}(1: 2)$ & & & 1.9 & 0.65 & 0.28 & 0.346 (PCE) & [333] \\
\hline & $\mathrm{FeS}_{2} / \mathrm{CdS}(1: 1)$ & & & 3.9 & 0.79 & 0.36 & 1.1 (PCE) & [333] \\
\hline 5 & $\mathrm{ITO} / \mathrm{ZnO} / \mathrm{FeS}_{2} \mathrm{NC} / \mathrm{MoO}_{3} / \mathrm{Au}$ & 100 & AM1.5 & & & & $1-4.5$ (EQE) & [345] \\
\hline 6 & $\mathrm{Fe} / \mathrm{FeS}_{2} \mathrm{NCs}$ & 5000 & UV, NIR & 1.2 & - & - & - & [253] \\
\hline \multirow[t]{4}{*}{7} & $\mathrm{ITO} / \mathrm{FeS}_{2} \mathrm{NCs} / \mathrm{Pt}$ & 100 & AM1.5 & 15.37 & 0.71 & 0.69 & 7.52 (PCE) & [318] \\
\hline & $\mathrm{ITO} / \mathrm{FeS}_{2} \mathrm{NCs} / \mathrm{Pt}$ & & AM1.5 & 12.63 & 0.71 & 0.64 & 5.74(PCE) & {$[318]$} \\
\hline & $\mathrm{ITO} / \mathrm{FeS}_{2} \mathrm{NCs} / \mathrm{Pt}$ & & AM1.5 & 15.14 & 0.71 & 0.68 & 7.31(PCE) & [318] \\
\hline & (with EDT treatment) & & & & & & & \\
\hline \multirow[t]{2}{*}{8} & $\mathrm{FeS}_{2} \mathrm{QDs} / \mathrm{CdS}$ & & AM1.5 & - & 1 & - & $1.64 \times 10^{4}(\mathrm{EQE})$ & [352] \\
\hline & $\mathrm{FeS}_{2}$ cubes/ CdS & & AM1.5 & & & & $1.97 \times 10^{4}(\mathrm{EQE})$ & [352] \\
\hline \multirow[t]{2}{*}{9} & P3HT:PCBM:FeS & 0.3 & AM1.5 & $8.65 \pm 0.11$ & $0.60 \pm 0.01$ & $53.6 \pm 1.4$ & $2.79 \pm 0.11$ (PCE) & [339] \\
\hline & (28 days air exposure) & $\mathrm{wt} \%$ & & & & & & \\
\hline
\end{tabular}




\section{WILEY-VCH}

\begin{tabular}{|c|c|c|c|c|c|c|c|}
\hline \multirow[t]{2}{*}{10} & ITO/PEDOT:PSS/ & White & 0.130 & 0.72 & 0.52 & 0.062 (ECE) & [353] \\
\hline & MEHPPV:FeS $2 / \mathrm{Al}$ & \multicolumn{6}{|l|}{ light } \\
\hline \multirow[t]{2}{*}{11} & $\mathrm{FeS}_{2}$-chain-CEs & AM1.5 & $15.3 \pm 0.1$ & $0.72 \pm 0.01$ & $0.65 \pm 0.01$ & $7.16 \pm 0.25$ (PCE) & [120] \\
\hline & $\mathrm{FeS}_{2}$-MN-CEs & AM1.5 & $10.4 \pm 0.2$ & $0.70 \pm 0.02$ & $0.58 \pm 0.01$ & $4.22 \pm 0.30(\mathrm{PCE})$ & [120] \\
\hline \multirow[t]{2}{*}{12} & $\mathrm{~s}-\mathrm{FeS}_{2} / \mathrm{FTO}$ & AM1.5 & 13.00 & 0.746 & 0.361 & 3.50 (PCE) & [154] \\
\hline & $\mathrm{m}-\mathrm{FeS}_{2} / \mathrm{FTO}$ & AM1.5 & 13.58 & 0.743 & 0.387 & 3.90 (PCE) & [154] \\
\hline 13 & $\mathrm{FeS}_{2} / \mathrm{FTO}$ & AM1.5 & 16.86 & 0.77 & 0.56 & 7.27 (IPCE) & [354] \\
\hline \multirow[t]{2}{*}{14} & $\mathrm{Cu} / \mathrm{Ni}_{0.05} \mathrm{Fe}_{0.95} \mathrm{~S}_{2} \mathrm{NCs} / \mathrm{Au}$ & AM1.5 & $19.7 \pm 0.3$ & $0.835 \pm$ & $70.8 \pm 1.8$ & $11.8 \pm 0.3(\mathrm{PCE})$ & [340] \\
\hline & & & & 0.003 & \multicolumn{3}{|l|}{$(\%)$} \\
\hline
\end{tabular}

\section{Conclusion}

This review has discussed in detail the issues and the possible remedies to address those issues which have recently been mentioned in the brief review by Shukla et al, ${ }^{[21]}$ regarding the use of pyrite in photovoltaic. Pyrite based photovoltaic is still in the research and development stage where low open-circuit voltage $\left(\mathrm{V}_{\mathrm{OC}} \leq 187 \mathrm{mV}\right)$ and solar conversion efficiency $<3 \%$ are the foremost challenges. The reasons for this low open circuit values are: Although synthesis of pyrite NCs or thin films by synthetic routes; hot injection, solvothermal/ hydrothermal methods have been observed to yield high quality pyrite NCs but surface stability of pyrite is still challenging especially for NCs. Surface defects at the grain boundaries are the main barrier in pyrite photovoltaics whether the films are polycrystalline or nanocrystalline. The accumulation of hole charge carriers at these boundaries leads to fast carrier recombination and consequently low photovoltage. Appropriate band alignment 


\section{WILEY-VCH}

(conduction offset) of individual layers while designing pyrite solar cell can resolve small photocurrent related issues.

Synthetic approaches and the type of precursors used are important factor to control the iron to sulphur ratio and to improve the structural, morphological, surface, optical and electrical properties of pyrite nanocrystals or thin films. The surface passivation of pyrite NCs or thin films can reduce surface oxidation and surface defect states either by ligands or by surface encapsulation. The deep donor defect states causing disruption in charge carrier flow can be minimized by alloying, doping or by making hybrid structures of pyrite. Interface engineering by hole transport layer or by electron transport layer or by both can passivate interface traps to reduce recombination. Nano-engineering of pyrite structures can also reduce grain boundaries effects e.g., aligned nanowires (1D nano pyrite). The synthesis of pyrite single crystals can offer a better prospect towards pyrite with less sulfur vacancies without bulk deep states. Phase pure pyrite thin films obtained via single source precursor approach is a synthetic route without impurity problems and it does not require any post annealing or expensive or sophisticated equipment or toxic materials or surfactants or long reaction time. This approach has the potential to scale up for the production of high quality material for device fabrication. The ultimate goal is to enhance the photovoltaic properties of pyrite.

Every cloud has a silver lining; it is not afar when the mysterious fool's gold will prove itself more than gold to the research community. Pyrite research forum is open for development and improvements (Figure 28). 


\section{WILEY-VCH}

Iron to sulphur ratio and the surface defects are major issues hindering the commercial use of pyrite. Synthetic approaches are important factor to control the iron to sulphur ratio and to improve the structural, morphological, surface, optical and electrical properties of pyrite nanocrystals or thin films. The ultimate goal is to enhance the photovoltaic properties of pyrite.

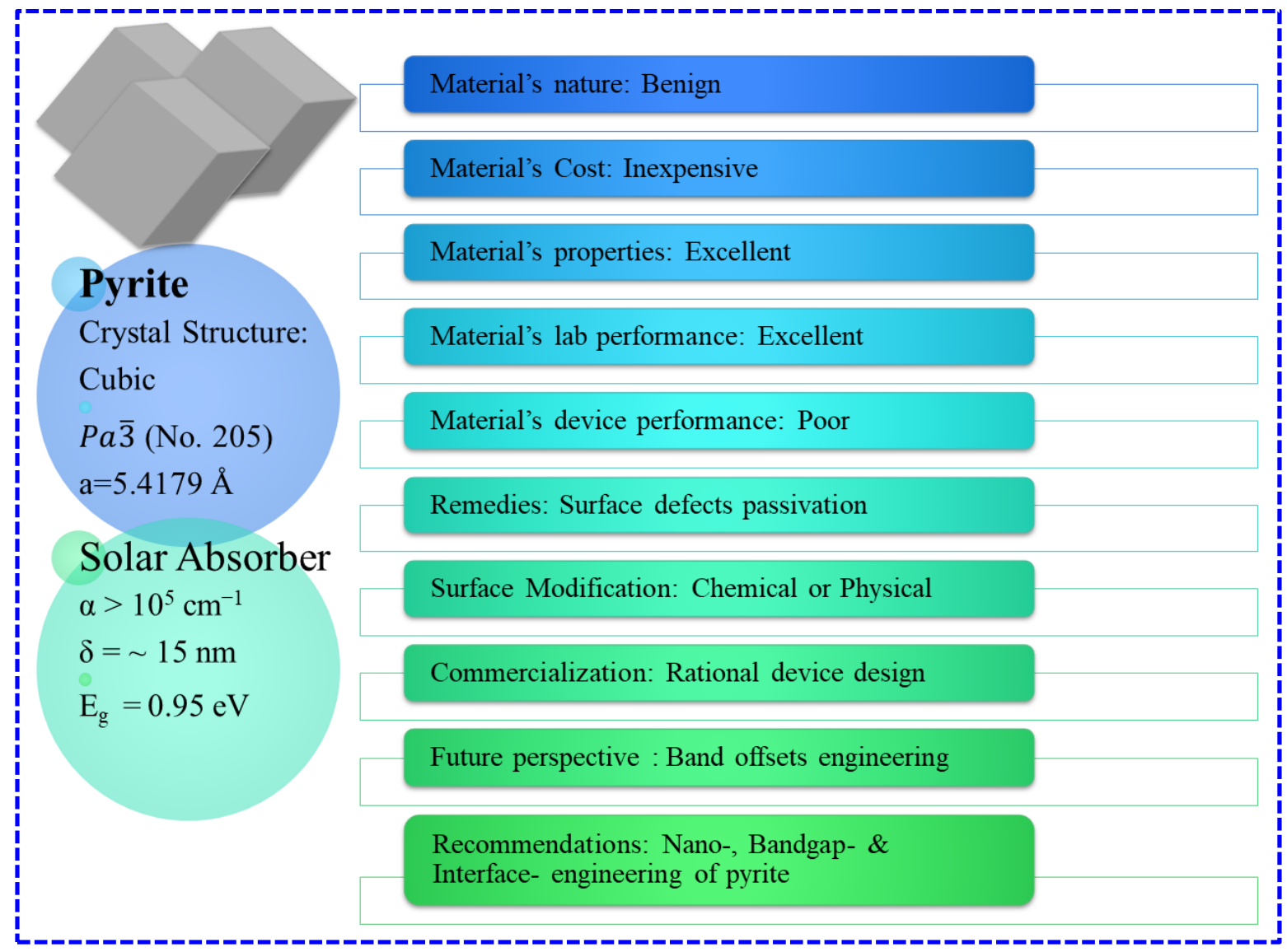

Figure 28. Pyrite photovoltaics 


\section{WILEY-VCH}

\section{Acknowledgements}

SK thanks the Higher Education Commission of Pakistan for an IRSIP scholarship and Nanoscience and Technology Department (NS\&TD), National Centre for Physics (NCP) Islamabad, Pakistan for providing research facilities as hosted researcher.

Keywords: Iron pyrite, nanocrystals, optical properties, photovoltaics, thin films.

\section{References}

[1] C. S. Tao, J. Jiang, and M. Tao, Sol. Energy Mater. Sol. Cells 2011, 95, 3176.

[2] L. M. Peter, Philos. Trans. R. Soc., A 2011, 369, 1840.

[3] S. Binetti, M. Acciarri, A. Le Donne, M. Morgano, and Y. Jestin,Int. J. Photoenergy 2013, 2013.

[4] S. Hänni, G. Bugnon, G. Parascandolo, M. Boccard, J. Escarré, M. Despeisse, F. Meillaud, and C. Ballif, Prog. Photovoltaics 2013, 21, 821.

[5] O. Shevaleevskiy, Pure Appl. Chem. 2008, 80, 2079.

[6] P. K. Nayak, J. Bisquert, and D. Cahen, Adv. Mater. 2011, 23, 2870.

[7] M. A. Green, A. Ho-Baillie, and H. J. Snaith, Nat. Photonics 2014, 8, 506.

[8] H. S. Jung and N. G. Park, Small 2015, 11, 10.

[9] B. Parida, S. Iniyan, and R. Goic, Renewable Sustainable Energy Rev. 2011, 15, 1625.

[10] L. El Chaar and N. El Zein, Renewable Sustainable Energy Rev. 2011, 15, 2165.

[11] F. Alharbi, J. D. Bass, A. Salhi, A. Alyamani, H.-C. Kim, and R. D. Miller, Renewable energy 2011, 36, 2753.

[12] K. Chopra, P. Paulson, and V. Dutta, Prog. Photovoltaics 2004, 12, 69.

[13] C. Wadia, A. P. Alivisatos, and D. M. Kammen, Environ. Sci. Technol. 2009, 43, 2072. 


\section{WILEY-VCH}

[14] Z. Abdin, M. Alim, R. Saidur, M. Islam, W. Rashmi, S. Mekhilef, and A. Wadi, Renewable Sustainable Energy Rev. 2013, 26, 837.

[15] C. Clavero, Nat. Photonics 2014, 8, 95.

[16] M. A. Green, K. Emery, Y. Hishikawa, W. Warta, and E. D. Dunlop, Prog. Photovoltaics 2015, 23, 1.

[17] A. Ennaoui, S. Fiechter, C. Pettenkofer, N. Alonso-Vante, K. Büker, M. Bronold, C. Höpfner, and H. Tributsch, Sol. Energy Mater. Sol. Cells 1993, 29, 289.

[18] A. Ennaoui and H. Tributsch, Sol. cells 1984, 13, 197.

[19] J. Kalowekamo and E. Baker, Sol. Energy 2009, 83, 1224.

[20] T. Unold and H.-W. Schock, Annu. Rev. Mater. Res. 2011, 41, 297.

[21] S. Shukla, J. W. Ager, Q. Xiong, and T. Sritharan, Energy Technology 2018, 6, 8.

[22] D. J. Vaughan and J. R. Craig, Mineral chemistry of metal sulfides. Vol. 493. 1978: Cambridge University Press Cambridge.

[23] G. Zhao, J. Callaway, and M. Hayashibara, Phys. Rev. B 1993, 48, 87937.

[24] W. Folkerts, G. Sawatzky, C. Haas, R. De Groot, and F. Hillebrecht, J. Phys. C: Solid State Phys. 1987, 20, 4135.

[25] R. T. Lowson, Chem. Rev. 1982, 82, 461.

[26] M. S. Schmokel, L. Bjerg, S. Cenedese, M. R. V. Jorgensen, Y.-S. Chen, J. Overgaard, and B. B. Iversen, Chem. Sci. 2014, 5, 1408.

[27] J.-Y. Zhao and J.-M. Zhang, J. Phys. Chem. C, 2017, 121, 19334.

[28] T. A. Bither, R. J. Bouchard, W. H. Cloud, P. C. Donohue, and W. J. Siemons, Inorg. Chem. 1968, 7, 2208.

[29] M. Birkholz, S. Fiechter, A. Hartmann, and H. Tributsch, Phys. Rev. B 1991, 43, 11926. 


\section{WILEY-VCH}

[30] C. Ho, Y. Huang, and K. Tiong, J. Alloys Compd. 2006, 422, 321.

[31] O. Kuvandikov, K. O. Shakarov, Z. Shodiev, and G. Rabbimova, J. Commun. Technol. Electron. 2007, 52, 1062.

[32] J. Hu, Y. Zhang, M. Law, and R. Wu, J. Am. Chem. Soc. 2012, 134, 13216.

[33] D. Pridmore and R. Shuey, Am. Mineral. 1976, 61, 248.

[34] P. Abraitis, R. Pattrick, and D. Vaughan, Int. J. Miner. Process. 2004, 74, 41.

[35] Y.-Q. Li, J.-H. Chen, Y. Chen, and J. Guo, Trans. Nonferrous Met. Soc. China 2011, 21, 1887.

[36] R. Sun, M. Chan, S. Kang, and G. Ceder, Phys. Rev. B 2011, 84, 035212.

[37] A. Ennaoui, S. Fiechter, W. Jaegermann, and H. Tributsch, J. Electrochem. Soc. 1986, $133,97$.

[38] I. Ferrer, D. Nevskaia, C. De las Heras, and C. Sanchez, Solid State Commun. 1990, $74,913$.

[39] D. Rickard and G. W. Luther, Chem. Rev. 2007, 107, 514.

[40] S. Kissin and S. Scott. Phase relations of intermediate pyrrhotites. in Economic Geology. 1972: ECONOMIC GEOLOGY PUBL CO 5808 SOUTH RAPP ST, STE 209, LITTLETON, CO 80120-1942.

[41] H. Zoka, L. A. Taylor, and S. Takeno, J. Sci. Hiroshima Univ. Serv 1973, 7, 37.

[42] S. A. Kissin, Phase relations in a portion of the Fe-S system 1974, Thesis (Ph. D.)-University of Toronto.

[43] L. Taylor, Carnegie Inst. Washington Yearbook 1970, 68, 259.

[44] R. Sun, M. Chan, and G. Ceder, Phys. Rev. B 2011, 83, 235311. 


\section{WILEY-VCH}

[45] S. Khalid, E. Ahmed, Y. Khan, S. Nawaz, M. Ramzan, N. Khalid, and W. Ahmed, Iron Pyrite $\left(\mathrm{FeS}_{2}\right)$ : Sustainable Photovoltaic Material, in Micro and Nanomanufacturing Volume II. 2018, Springer. p. 281-318.

[46] G. Lee and M. Kang, Curr. Appl. Phys. 2013, 13, 1482.

[47] A. Raturi, S. Waita, B. Aduda, and T. Nyangonda, Renewable energy 2000, 20, 37.

[48] Y. Zhu, L. Suo, T. Gao, X. Fan, F. Han, and C. Wang, Electrochem. Commun. 2015, $54,18$.

[49] Y. Xin, Z. Li, W. Wu, B. Fu, and Z. Zhang, ACS Sustainable Chem. Eng. 2016, 4, 6659.

[50] C. Julien and G. Nazri, Solid state batteries: materials design and optimization. Vol. 271. 1994: Springer.

[51] S. S. Zhang and D. T. Tran, J. Electrochem. Soc. 2016, 163, A792.

[52] J. M. Whiteley, S. Hafner, S. S. Han, S. C. Kim, K. H. Oh, and S. H. Lee, Adv. Energy Mater. 2016, 6.

[53] H. Siyu, L. Xinyu, L. QingYu, and C. Jun, J. Alloys Compd. 2009, 472, L9.

[54] T. A. Yersak, H. A. Macpherson, S. C. Kim, V. D. Le, C. S. Kang, S. B. Son, Y. H. Kim, J. E. Trevey, K. H. Oh, and C. Stoldt, Adv. Energy Mater. 2013, 3, 120.

[55] S. S. Zhang and D. T. Tran, J. Mater. Chem. A 2016, 4, 4371.

[56] K. Sun, C. A. Cama, R. A. DeMayo, D. C. Bock, X. Tong, D. Su, A. C. Marschilok, K. J. Takeuchi, E. S. Takeuchi, and H. Gan, J. Electrochem. Soc. 2017, 164, A6039.

[57] Z. Shadike, Y.-N. Zhou, F. Ding, L. Sang, K.-W. Nam, X.-Q. Yang, and Z.-W. Fu, J. Power Sources 2014, 260, 72.

[58] K. Zhang, M. Park, L. Zhou, G. H. Lee, J. Shin, Z. Hu, S. L. Chou, J. Chen, and Y. M. Kang, Angew. Chem., Int. Ed. 2016, 55, 12822. 


\section{WILEY-VCH}

[59] A. Douglas, R. Carter, L. Oakes, K. Share, A. P. Cohn, and C. L. Pint, ACS Nano 2015, 9, 11156.

[60] S. Cheng, J. Wang, H. Lin, W. Li, Y. Qiu, Z. Zheng, X. Zhao, and Y. Zhang, J. Mater. Sci. 2017, 52, 2442.

[61] W. Ma, X. Liu, X. Lei, Z. Yuan, and Y. Ding, Chem. Eng. J. 2018, 334, 725.

[62] A. Dubey, S. K. Singh, B. Tulachan, M. Roy, G. Srivastava, D. Philip, S. Sarkar, and M. Das, RSC Adv. 2016, 6, 16859.

[63] M. Gong, A. Kirkeminde, N. Kumar, H. Zhao, and S. Ren, Chem. Commun. 2013, 49, 9260.

[64] C. Uhlig, E. Guenes, A. S. Schulze, M. T. Elm, P. J. Klar, and S. Schlecht, J. Electron. Mater. 2014, 43, 2362.

[65] C. Wang, Y. Niu, J. Jiang, Y. Chen, H. Tian, R. Zhang, T. Zhou, J. Xia, Y. Pan, and S. Wang, Nano Energy, 2018, 45, 432.

[66] X. Liu, J. Y. Ho, M. Wong, H. S. Kwok, and Z. Liu, RSC Adv. 2016, 6, 8290.

[67] B. Kolb and A. M. Kolpak, Phys. Rev. B 2013, 88, 235208.

[68] S. Liu, J. Wu, P. Yu, Q. Ding, Z. Zhou, H. Li, C.-c. Lai, Y.-L. Chueh, and Z. Wang, Nanoscale Res. Lett. 2014, 9, 1.

[69] Y. Zhang, J. Hu, M. Law, and R. Wu, Phys. Rev. B 2012, 85, 085314.

[70] S. Bae, D. Kim, and W. Lee, Appl. Catal., B 2013, 134, 93.

[71] S. Liu, M. Li, S. Li, H. Li, and L. Yan, Appl. Surf. Sci. 2013, 268, 213.

[72] G. Kaur, B. Singh, P. Singh, K. Singh, A. Thakur, M. Kumar, R. Bala, and A. Kumar, ChemistrySelect 2017, 2, 2166.

[73] Y. Duan, D. S. Han, B. Batchelor, and A. Abdel-Wahab, Colloids Surf., A 2016, 490, 326. 


\section{WILEY-VCH}

[74] C. Gil-Lozano, A. Davila, E. Losa-Adams, A. Fairén, and L. Gago-Duport, Sci. Rep. 2017, 7, 43703.

[75] J. R. Morse, J. F. Callejas, A. J. Darling, and R. E. Schaak, Chem. Commun. 2017, 53, 4807.

[76] B. Chakraborty, B. Show, S. Jana, B. C. Mitra, S. K. Maji, B. Adhikary, N. Mukherjee, and A. Mondal, Electrochim. Acta 2013, 94, 7.

[77] G. Srivastava, A. Das, T. S. Kusurkar, M. Roy, S. Airan, R. K. Sharma, S. K. Singh, S. Sarkar, and M. Das, Mater. Express 2014, 4, 23.

[78] C. K. Das, G. Srivastava, A. Dubey, S. Verma, M. Saxena, M. Roy, N. K. Sethy, K. Bhargava, S. K. Singh, S. Sarkar, D. Philip, and M. Das, RSC Adv. 2016, 6, 67029.

[79] Y. Bai, J. Yeom, M. Yang, S.-H. Cha, K. Sun, and N. A. Kotov, J. Phys. Chem. C 2013, 117, 2567.

[80] M. Leser, J. Pegan, M. El Makkaoui, J. C. Schlatterer, M. Khine, M. Law, and M. Brenowitz, Lab Chip 2015, 15, 1646.

[81] Q. Jin, J. Liu, W. Zhu, Z. Dong, Z. Liu, and L. Cheng, ACS Appl. Mater. Interfaces, 2018, 10,332 .

[82] J. Zong, Y. Zhu, J. Shen, X. Yang, and C. Li, J. Colloid Interface Sci. 2013, 402, 50.

[83] A. Layek, S. Middya, and P. P. Ray, J. Renewable Sustainable Energy, 2013, 5, 031601.

[84] A. M. Golsheikh, N. Huang, H. Lim, C. Chia, I. Harrison, and M. Muhamad, Chem. Eng. J. 2013, 218, 276.

[85] M. Wang, D. Xue, H. Qin, L. Zhang, G. Ling, J. Liu, Y. Fang, and L. Meng, Mater. Sci. Eng., B 2016, 204, 38. 


\section{WILEY-VCH}

[86] M. Gong, R. Sakidja, Q. Liu, R. Goul, D. Ewing, M. Casper, A. Stramel, A. Elliot, and J. Z. Wu, Adv. Opt. Mater. 2018, 6, 1701241.

[87] S. Nazir and U. Schwingenschlögl, RSC Adv. 2013, 3, 4518.

[88] A. J. McGrath, C. Yu, H. Fiedler, J. Butkus, J. M. Hodgkiss, and J. E. Halpert, J. Phys. Chem. C 2017, 121, 8220.

[89] W. Zhang, G. Xu, Y. Cheng, L. Chen, Q. Huo, and S. Liu, Dalton Trans. 2018, 47, 5217.

[90] L. Liu, Z. Yuan, C. Qiu, and J. Liu, Solid State Ionics, 2013, 241, 25.

[91] Y. Zhu, X. Fan, L. Suo, C. Luo, T. Gao, and C. Wang, ACS Nano 2016, 10, 1529.

[92] X. Wen, X. Wei, L. Yang, and P. K. Shen, J. Mater. Chem. A 2015, 3, 2090.

[93] W. Qiu, J. Xia, H. Zhong, S. He, S. Lai, and L. Chen, Electrochim. Acta 2014, 137, 197.

[94] F. Cao, G. Pan, J. Chen, Y. Zhang, and X. Xia, J. Power Sources, 2016, 303, 35.

[95] X. Xu, J. Liu, Z. Liu, J. Shen, R. Hu, J. Liu, L. Ouyang, L. Zhang, and M. Zhu, ACS Nano, 2017, 11, 9033.

[96] Y. Zhong, J. Liu, Z. Lu, and H. Xia, Mater. Lett. 2016, 166, 223.

[97] W. Chen, S. Qi, L. Guan, C. Liu, S. Cui, C. Shen, and L. Mi, J. Mater. Chem. A 2017, $5,5332$.

[98] W. Zhao, C. Guo, and C. M. Li, J. Mater. Chem. A 2017, 5, 19195.

[99] Z. Liu, T. Lu, T. Song, X.-Y. Yu, X. W. Lou, and U. Paik, Energy Environ. Sci. 2017, $10,1576$.

[100] Y. Chen, X. Hu, B. Evanko, X. Sun, X. Li, T. Hou, S. Cai, C. Zheng, W. Hu, and G. D. Stucky, Nano Energy 2018, 46, 117.

[101] L. Pei, Y. Yang, H. Chu, J. Shen, and M. Ye, Ceram. Int. 2016, 42, 5053. 


\section{WILEY-VCH}

[102] D. T. Pham, J. P. Baboo, J. Song, S. Kim, J. Jo, V. Mathew, M. H. Alfaruqi, B. Sambandam, and J. Kim, Nanoscale 2018, 10, 5938.

[103] G. Kaur, D. Pooja, M. Kumar, A. Thakur, R. Bala, and A. Kumar, Phys. Chem. Chem. Phys. 2017, 19, 32412.

[104] W. Gao, R. Razavi, and A. Fakhri, Int. J. Biol. Macromol. 2018, 114, 357.

[105] J. Rashid, S. Saleem, S. U. Awan, A. Iqbal, R. Kumar, M. Barakat, M. Arshad, M. Zaheer, M. Rafique, and M. Awad, RSC Adv. 2018, 8, 11935.

[106] M. Lashgari and P. Zeinalkhani, Nano Energy 2018, 48, 361.

[107] M. S. Faber, M. A. Lukowski, Q. Ding, N. S. Kaiser, and S. Jin, J. Phys. Chem. C 2014, 118, 21347.

[108] D.-Y. Wang, M. Gong, H.-L. Chou, C.-J. Pan, H.-A. Chen, Y. Wu, M.-C. Lin, M. Guan, J. Yang, and C.-W. Chen, J. Am. Chem. Soc. 2015, 137, 1587.

[109] M. Barawi, I. J. Ferrer, E. Flores, S. Yoda, J. R. Ares, and C. Sánchez, J. Phys. Chem. C 2016, $120,9547$.

[110] D.-Y. Wang, C.-H. Li, S.-S. Li, T.-R. Kuo, C.-M. Tsai, T.-R. Chen, Y.-C. Wang, C.W. Chen, and C.-C. Chen, Sci. Rep. 2016, 6, 20397.

[111] S. Zhao, S. Guo, C. Zhu, J. Gao, H. Li, H. Huang, Y. Liu, and Z. Kang, RSC Adv. 2017, 7, 1376.

[112] Y. Fan, D. Wang, D. Han, Y. Ma, S. Ni, Z. Sun, X. Dong, and L. Niu, Nanoscale 2017, 9, 5887.

[113] Z.-H. Diao, X.-R. Xu, D. Jiang, G. Li, J.-J. Liu, L.-J. Kong, and L.-Z. Zuo, J. Hazard. Mater. 2017, 327, 108 .

[114] M. Gong, Q. Liu, R. Goul, D. Ewing, M. Casper, A. Stramel, A. Elliot, and J. Z. Wu, ACS Appl. Mater. Interfaces 2017, 9, 27801. 


\section{WILEY-VCH}

[115] N. Gupta, G. Alapatt, R. Podila, R. Singh, and K. Poole,Int. J. Photoenergy 2009, 2009.

[116] M. L. Brongersma, Y. Cui, and S. Fan, Nat. Mater. 2014, 13, 451.

[117] H. Ramsurn and R. B. Gupta, ACS Sustainable Chem. Eng. 2013, 1, 779.

[118] H. Xian, J. Zhu, X. Liang, and H. He, RSC Adv. 2016, 6, 31988.

[119] Z. He, S. H. Yu, X. Zhou, X. Li, and J. Qu, Adv. Funct. Mater. 2006, 16, 1105.

[120] Z. Wei, Y. Qiu, H. Chen, K. Yan, Z. Zhu, Q. Kuang, and S. Yang, J. Mater. Chem. A 2014, 2, 5508 .

[121] X. Zhang, Y. Xu, G. Guo, C. Ji, H. Tao, L. Shen, and N. Bao, J. Mater. Sci.: Mater. Electron. 2017, 28, 12717.

[122] N. T. K. Thanh, N. Maclean, and S. Mahiddine, Chem. Rev. 2014, 114, 7610.

[123] J. J. De Yoreo and P. G. Vekilov, Rev. Mineral. Geochem. 2003, 54, 57.

[124] W. Ostwald, Z. Phys. Chem 1897, 22, 289.

[125] V. K. L. Mer, Ind. Eng. Chem. 1952, 44, 1270.

[126] V. K. LaMer and R. H. Dinegar, J. Am. Chem. Soc. 1950, 72, 4847.

[127] X. Zhang, Y. Xu, G. Guo, C. Ji, H. Tao, L. Shen, and N. Bao, J. Mater. Sci.: Mater. Electron. 2017, 28, 12717.

[128] J. M. Rhodes, C. A. Jones, L. B. Thal, and J. E. Macdonald, Chem. Mater. 2017, 29, 8521.

[129] X. Chen, Z. Wang, X. Wang, J. Wan, J. Liu, and Y. Qian, Inorg. Chem. 2005, 44, 951.

[130] P. Gao, Y. Xie, L. Ye, Y. Chen, and Q. Guo, Cryst. Growth Des. 2006, 6, 583.

[131] Y. Hu, Z. Zheng, H. Jia, Y. Tang, and L. Zhang, J. Phys. Chem. C 2008, 112, 13037.

[132] C. Wadia, Y. Wu, S. Gul, S. K. Volkman, J. Guo, and A. P. Alivisatos, Chem. Mater. 2009, 21, 2568. 


\section{WILEY-VCH}

[133] D.-W. Wang, Q.-H. Wang, and T.-M. Wang, CrystEngComm 2010, 12, 755.

[134] J. Puthussery, S. Seefeld, N. Berry, M. Gibbs, and M. Law, J. Am. Chem. Soc. 2010, $133,716$.

[135] W. Li, M. Döblinger, A. Vaneski, A. L. Rogach, F. Jäckel, and J. Feldmann, J. Mater. Chem. 2011, 21, 17946.

[136] D. Wang, M. Wu, Q. Wang, T. Wang, and J. Chen, Ionics, 2011, 17, 163.

[137] M.-L. Li, Q.-Z. Yao, G.-T. Zhou, X.-F. Qu, C.-F. Mu, and S.-Q. Fu, CrystEngComm 2011, 13, 5936.

[138] C. Steinhagen, T. B. Harvey, C. J. Stolle, J. Harris, and B. A. Korgel, J. Phys. Chem. Lett. 2012, 3, 2352.

[139] H. A. Macpherson and C. R. Stoldt, ACS Nano 2012, 6, 8940.

[140] A. Kirkeminde, B. A. Ruzicka, R. Wang, S. Puna, H. Zhao, and S. Ren, ACS Appl. Mater. Interfaces 2012, 4, 1174.

[141] M. Cabán-Acevedo, M. S. Faber, Y. Tan, R. J. Hamers, and S. Jin, Nano Lett. 2012, $12,1977$.

[142] M. Cabán-Acevedo, D. Liang, K. S. Chew, J. P. DeGrave, N. S. Kaiser, and S. Jin, ACS Nano 2013, 7, 1731.

[143] J. M. Lucas, C.-C. Tuan, S. D. Lounis, D. K. Britt, R. Qiao, W. Yang, A. Lanzara, and A. P. Alivisatos, Chem. Mater. 2013, 25, 1615.

[144] M. Akhtar, M. A. Malik, F. Tuna, and P. O'Brien, J. Mater. Chem. A 2013, 1, 8766.

[145] M. Gong, A. Kirkeminde, and S. Ren, Sci. Rep. 2013, 3, 2092.

[146] D. Zhang, G. Wu, J. Xiang, J. Jin, Y. Cai, and G. Li, Mater. Sci. Eng., B 2013, 178, 483. 


\section{WILEY-VCH}

[147] B. Mao, Q. Dong, Z. Xiao, C. L. Exstrom, S. A. Darveau, T. E. Webber, B. D. Lund, H. Huang, Z. Kang, and J. Huang, J. Mater. Chem. A 2013, 1, 12060.

[148] M. Alam Khan, M. O. Manasreh, and Y.-M. Kang, Mater. Lett. 2014, 126, 181.

[149] M. Alam Khan and Y.-M. Kang, Mater. Lett. 2014, 132, 273.

[150] J. Wu, L. Liu, S. Liu, P. Yu, Z. Zheng, M. Shafa, Z. Zhou, H. Li, H. Ji, and Z. M. Wang, Nano Lett. 2014, 14, 6002.

[151] L. Li, M. Caban-Acevedo, S. N. Girard, and S. Jin, Nanoscale 2014, 6, 2112.

[152] T. S. Yoder, J. E. Cloud, G. J. Leong, D. F. Molk, M. Tussing, J. Miorelli, C. Ngo, S. Kodambaka, M. E. Eberhart, R. M. Richards, and Y. Yang, Chem. Mater. 2014, 26, 6743.

[153] L. Zhu, B. J. Richardson, and Q. Yu, Nanoscale 2014, 6, 1029.

[154] J. Xu, H. Xue, X. Yang, H. Wei, W. Li, Z. Li, W. Zhang, and C. S. Lee, Small 2014, 10,4754 .

[155] X. Shi, A. Tian, X. Xue, H. Yang, and Q. Xu, Mater. Lett. 2015, 141, 104.

[156] Z. Hu, Z. Zhu, F. Cheng, K. Zhang, J. Wang, C. Chen, and J. Chen, Energy Environ. Sci. 2015, 8, 1309.

[157] T. S. Yoder, M. Tussing, J. E. Cloud, and Y. Yang, J. Power Sources 2015, 274, 685.

[158] K. P. Bhandari, P. J. Roland, T. Kinner, Y. Cao, H. Choi, S. Jeong, and R. J. Ellingson, J. Mater. Chem. A 2015, 3, 6853.

[159] W. Liu, L. Xu, X. Li, C. Shen, S. Rashid, Y. Wen, W. Liu, and X. Wu, RSC Adv. 2015, $5,2449$.

[160] M. Walter, T. Zünd, and M. V. Kovalenko, Nanoscale 2015, 7, 9158.

[161] B. Li, L. Huang, M. Zhong, Z. Wei, and J. Li, RSC Adv. 2015, 5, 91103.

[162] M. Khabbaz and M. H. Entezari, J. Colloid Interface Sci. 2016, 470, 204. 


\section{WILEY-VCH}

[163] R. Miao, B. Dutta, S. Sahoo, J. He, W. Zhong, S. A. Cetegen, T. Jiang, S. P. Alpay, and S. L. Suib, J. Am. Chem. Soc. 2017, 139, 13604.

[164] Z. Wang, The Journal of Physical Chemistry B 2000, 104, 1153.

[165] A. Barnard and S. Russo, J. Mater. Chem. 2009, 19, 3389.

[166] A. Kirkeminde and S. Ren, J. Mater. Chem. A 2013, 1, 49.

[167] H. T. Kim, T. P. N. Nguyen, C.-d. Kim, and C. Park, Mater. Chem. Phys. 2014, 148, 1095.

[168] F. Jiang, L. T. Peckler, and A. J. Muscat, Cryst. Growth Des. 2015, 15, 3565.

[169] L. Zhu, B. J. Richardson, and Q. Yu, Chem. Mater. 2015, 27, 3516.

[170] T. K. Trinh, V. T. H. Pham, N. T. N. Truong, C. D. Kim, and C. Park, J. Cryst. Growth 2017, 461, 53.

[171] W. Shi, S. Song, and H. Zhang, Chem. Soc. Rev. 2013, 42, 5714.

[172] O. Schäf, H. Ghobarkar, and P. Knauth, Hydrothermal Synthesis of Nanomaterials, in Nanostructured Materials, Knauth P. and Schoonman J., Editors. 2002, Springer US. p. 23-41.

[173] C. Yanhua, Z. Yufeng, Z. Xiaogang, S. Yanfei, and D. Youzhong, Sci. China, Ser. G: Phys., Mech. Astron. 2005, 48, 188.

[174] L. Zhu, B. Richardson, J. Tanumihardja, and Q. Yu, CrystEngComm 2012, 14, 4188.

[175] J. Xia, J. Jiao, B. Dai, W. Qiu, S. He, W. Qiu, P. Shen, and L. Chen, RSC Adv. 2013, 3, 6132.

[176] M. Baghbanzadeh, L. Carbone, P. D. Cozzoli, and C. O. Kappe, Angew. Chem., Int. Ed. 2011, 50, 11312.

[177] J. Wu, Y. Liang, P. Bai, S. Zheng, and L. Chen, RSC Adv. 2015, 5, 65575.

[178] P. Kush, N. Mehra, and S. Deka, Science of Adv. Mater. 2013, 5, 788. 


\section{WILEY-VCH}

[179] D. A. Kitchaev and G. Ceder, Nat. Commun. 2016, 7, 13799.

[180] M. A. A. Schoonen and H. L. Barnes, Geochim. Cosmochim. Acta 1991, 55, 1495.

[181] W. W. Yu and X. Peng, Angew. Chem., Int. Ed. 2002, 41, 2368.

[182] Y. Yin and A. P. Alivisatos, Nature 2005, 437, 664.

[183] A. S. Barnard and S. P. Russo, Nanotechnology 2009, 20, 115702.

[184] A. Barnard and S. Russo, J. Phys. Chem. C 2007, 111, 11742.

[185] S. Mangham, M. Alam Khan, M. Benamara, and M. Manasreh, Mater. Lett. 2013, 97, 144.

[186] M. A. Khan, S. A. Little, Y. Makablah, S. Mangham, S. Lee, and M. Manasreh, MRS Online Proc. Libr. 2013, 1545, mrss13-1545-k03-17.

[187] Y. Liang, P. Bai, J. Zhou, T. Wang, B. Luo, and S. Zheng, CrystEngComm 2016, 18, 6262.

[188] L. Zhu, B. J. Richardson, and Q. Yu, Nanoscale 2014, 6, 1029.

[189] A. Sahu, A. Khare, D. D. Deng, and D. J. Norris, Chem. Commun. 2012, 48, 5458.

[190] P. P. Altermatt, T. Kiesewetter, K. Ellmer, and H. Tributsch, Sol. Energy Mater. Sol. Cells, 2002, 71, 181

[191] J. Wilcoxon, P. Newcomer, and G. Samara, Solid State Commun. 1996, 98, 581.

[192] A. Barnard and S. Russo, J. Phys. Chem. C 2009, 113, 5376.

[193] P. H.-L. Sit, M. H. Cohen, and A. Selloni, J. Phys. Chem. Lett. 2012, 3, 2409.

[194] Y. Bi, Y. Yuan, C. L. Exstrom, S. A. Darveau, and J. Huang, Nano Lett. 2011, 11, 4953.

[195] B.-B. Yu, X. Zhang, Y. Jiang, J. Liu, L. Gu, J.-S. Hu, and L.-J. Wan, J. Am. Chem. Soc. 2015, 137, 2211.

[196] W. Li, T. Dittrich, F. Jäckel, and J. Feldmann, Small 2014, 10, 1194. 


\section{WILEY-VCH}

[197] G. Zhai, R. Xie, H. Wang, J. Zhang, Y. Yang, H. Wang, X. Li, X. Liu, and B. Xu, J. Alloys Compd. 2016, 674, 9.

[198] M. A. Green, Prog. Photovoltaics, 2012, 20, 472.

[199] Y. Liu, L. Meng, and L. Zhang, Thin Solid Films 2005, 479, 83.

[200] Z. Luan, L. Huang, F. Wang, and L. Meng, Appl. Surf. Sci. 2011, 258, 1505.

[201] G. Smestad, A. Ennaoui, S. Fiechter, H. Tributsch, W. Hofmann, M. Birkholz, and W. Kautek, Sol. Energy Mater. 1990, 20, 149.

[202] T. Li, H. Liu, Z. Wu, Y. Liu, Z. Guo, and H. Zhang, Nanoscale 2016, 8, 11792.

[203] X. Wang, G. Wang, J. Chen, X. Zhu, J. Tian, C. Jiang, Y. Zhang, X. Liu, and R. Wang, Mater. Lett. 2013, 110, 144.

[204] H. Liu and D. Chi, J. Vac. Sci. Technol., A 2012, 30, $04 \mathrm{D} 102$.

[205] P. S. Patil, Mater. Chem. Phys. 1999, 59, 185.

[206] L. MacLean, T. Tyliszczak, P. Gilbert, D. Zhou, T. Pray, T. Onstott, and G. Southam, Geobiology 2008, 6, 471.

[207] C. De las Heras, I. Ferrer, and C. Sanchez, J. Appl. Phys. 1993, 74, 4551.

[208] M. Bronold, S. Kubala, C. Pettenkofer, and W. Jaegermann, Thin Solid Films 1997, $304,178$.

[209] A. Baruth, M. Manno, D. Narasimhan, A. Shankar, X. Zhang, M. Johnson, E. Aydil, and C. Leighton, J. Appl. Phys. 2012, 112, 054328.

[210] X. Zhang, T. Scott, T. Socha, D. Nielsen, M. Manno, M. Johnson, Y. Yan, Y. Losovyj, P. Dowben, and E. S. Aydil, ACS Appl. Mater. Interfaces 2015, 7, 14130.

[211] Y. Sasaki, A. Sugii, and K. Ishii, J. Mater. Sci. letters 1999, 18, 1193. 


\section{WILEY-VCH}

[212] J. Clamagirand, J. Ares, I. Ferrer, and C. Sánchez. Near room temperature power factor of metal sulfides films. in 9TH EUROPEAN CONFERENCE ON THERMOELECTRICS: ECT2011. 2012: American Institute of Physics.

[213] A. Pascual, S. Yoda, M. Barawi, J. M. Clamagirand, J. R. Ares, I. J. Ferrer, and C. Sánchez, J. Phys. Chem. C 2014, 118, 26440.

[214] D. Yokoyama, K. Namiki, and Y. Yamada, J. Radioanal. Nucl. Chem. 2006, 268, 283.

[215] R. Henda, O. Al-Shareeda, A. McDonald, and A. Pratt, Appl. Phys. A 2012, 108, 967.

[216] A. Clayton, S. Irvine, V. Barrioz, W. Brooks, G. Zoppi, I. Forbes, K. D. Rogers, D. W. Lane, K. Hutchings, and S. Roncallo, Thin Solid Films 2011, 519, 7360.

[217] B. Meester, L. Reijnen, A. Goossens, and J. Schoonman, Chem. Vap. Deposition 2000, $6,121$.

[218] N. Berry, M. Cheng, C. L. Perkins, M. Limpinsel, J. C. Hemminger, and M. Law, Adv. Energy Mater. 2012, 2, 1124.

[219] L. Samad, M. Cabán-Acevedo, M. J. Shearer, K. Park, R. J. Hamers, and S. Jin, Chem. Mater. 2015, 27, 3108.

[220] M. Akhtar, A. L. Abdelhady, M. Azad Malik, and P. O'Brien, J. Cryst. Growth 2012, $346,106$.

[221] S. Khalid, E. Ahmed, M. Azad Malik, D. J. Lewis, S. Abu Bakar, Y. Khan, and P. O'Brien, New J. Chem. 2015, 39, 1013.

[222] C. D. Sentman, M. O'Brien, and C. A. Wolden, J. Vac. Sci. Technol., A 2013, 32, 021201.

[223] V. Antonucci, A. Arico, N. Giordano, P. Antonucci, U. Russo, D. Cocke, and F. Crea, Sol. cells, 1991, 31, 119.

[224] J. Zavašnik and A. Rečnik, J. Cryst. Growth 2013, 367, 18. 


\section{WILEY-VCH}

[225] Z. Luan, Y. Wang, F. Wang, L. Huang, and L. Meng, Thin Solid Films 2011, 519, 7830.

[226] D. Mazón-Montijo, M. Nair, and P. Nair, ECS J. Solid State Sci. Technol. 2013, 2, P465.

[227] A. Yamamoto, M. Nakamura, A. Seki, E. Li, A. Hashimoto, and S. Nakamura, Sol. Energy Mater. Sol. Cells 2003, 75, 451.

[228] D. G. Moon, A. Cho, J. H. Park, S. Ahn, H. Kwon, Y. S. Cho, and S. Ahn, J. Mater. Chem. A 2014, 2, 17779.

[229] Z. Luan, F. Wang, D. Yao, L. Huang, and L. Meng, Mater. Res. Bull. 2011, 46, 1577.

[230] S. Seefeld, M. Limpinsel, Y. Liu, N. Farhi, A. Weber, Y. Zhang, N. Berry, Y. J. Kwon, C. L. Perkins, and J. C. Hemminger, J. Am. Chem. Soc. 2013, 135, 4412.

[231] A. M. Sajimol, P. B. Anand, K. M. Anilkumar, and S. Jayalekshmi, Polym. Int. 2013, $62,670$.

[232] Y.-Y. Lin, D.-Y. Wang, H.-C. Yen, H.-L. Chen, C.-C. Chen, C.-M. Chen, C.-Y. Tang, and C.-W. Chen, Nanotechnology 2009, 20, 405207.

[233] Z. Guo and X. Wang, Angew. Chem., Int. Ed. 2018, 57, 5898.

[234] G. Pimenta and W. Kautek, Thin Solid Films 1994, 238, 213.

[235] S. Bausch, B. Sailer, H. Keppner, G. Willeke, E. Bucher, and G. Frommeyer, Appl. Phys. Lett. 1990, 57, 25.

[236] M. Teo, S. Kulinich, O. Plaksin, and A. Zhu, J. Phys. Chem. A 2010, 114, 4173.

[237] M. Umehara, Y. Takeda, H. Azuma, and T. Motohiro, Japanese J. Appl. Phys. 2012, 51, 02BP10.

[238] J. P. DeGrave, D. Liang, and S. Jin, Nano Lett. 2013, 13, 2704.

[239] A. I. Hochbaum and P. Yang, Chem. Rev. 2009, 110, 527. 


\section{WILEY-VCH}

[240] M. K. Sunkara, C. Pendyala, D. Cummins, P. Meduri, J. Jasinski, V. Kumar, H. Russell, E. Clark, and J. Kim, J. Phys. D: Appl. Phys. 2011, 44, 174032.

[241] V. Bessergenev, R. Pereira, and A. Botelho do Rego, Surf. Coat. Technol. 2007, 201, 9141.

[242] S. P. Adusumilli, T. P. Dhakal, and C. R. Westgate. Synthesis of Iron Pyrite Film through Low Temperature Atmospheric Pressure Chem. Vap. Deposition. in MRS Proceedings. 2012: Cambridge Univ Press.

[243] M. A. Malik, N. Revaprasadu, and K. Ramasamy, Nanoscience: Nanostructures Through Chemistry, 2012, 1, 29.

[244] A. J. Martinolich and J. R. Neilson, J. Am. Chem. Soc. 2014, 136, 15654.

[245] P. Bai, S. Zheng, C. Chen, and H. Zhao, Cryst. Growth Des. 2014, 14, 4295.

[246] T. K. Trinh, N. T. N. Truong, V. T. H. Pham, H. Kim, and C. Park, Korean J. Chem. Eng. 2018. (https://doi.org/10.1007/s11814-018-0060-6)

[247] D. Santos-Cruz, S. Mayén-Hernández, F. de Moure-Flores, J. Arias-Cerón, and J. Santos-Cruz, Mater. Sci. Semicond. Process. 2016, 42, 383.

[248] T. P. Mernagh and A. G. Trudu, Chem. Geol. 1993, 103, 113.

[249] L. Huang and L. Meng, Mater. Chem. Phys. 2010, 124, 413.

[250] L. Y. M. L. Z. Xiujuan, Chin. J. Mater. Res. 2004, 4, 005.

[251] B. Thomas, K. Ellmer, M. Müller, C. Höpfner, S. Fiechter, and H. Tributsch, J. Cryst. Growth 1997, 170, 808.

[252] B. Kilic, J. Roehling, and O. T. Ozmen, J. Nanoelectron. Optoelectron. 2013, 8, 260.

[253] X. Qiu, M. Liu, T. Hayashi, M. Miyauchi, and K. Hashimoto, Chem. Commun. 2013, $49,1232$. 


\section{WILEY-VCH}

[254] K. Sun, Z. Su, J. Yang, Z. Han, F. Liu, Y. Lai, J. Li, and Y. Liu, Thin Solid Films 2013, $542,123$.

[255] J. M. LaForge, B. Gyenes, S. Xu, L. K. Haynes, L. V. Titova, F. A. Hegmann, and M. J. Brett, Sol. Energy Mater. Sol. Cells 2013, 117, 306.

[256] J. Y. Seto, J. Appl. Phys. 2008, 46, 5247.

[257] D. Lichtenberger, K. Ellmer, R. Schieck, S. Fiechter, and H. Tributsch, Thin Solid Films 1994, 246, 6.

[258] L. Huang and L. Meng, Mater. Sci. Eng., B 2007, 137, 310.

[259] X. Zhang, M. Manno, A. Baruth, M. Johnson, E. S. Aydil, and C. Leighton, ACS Nano, 2013, 7, 2781.

[260] A. Rollett, F. Humphreys, G. S. Rohrer, and M. Hatherly, Recrystallization and related annealing phenomena. 2004: Elsevier.

[261] R. Morrish, R. Silverstein, and C. A. Wolden, J. Am. Chem. Soc. 2012, 134, 17854.

[262] M. Vahidi, S. Lehner, P. Buseck, and N. Newman, Acta Mater. 2013, 61, 7392.

[263] H. Duan, Y. Zheng, Y. Dong, X. Zhang, and Y. Sun, Mater. Res. Bull. 2004, 39, 1861.

[264] J. Tauc and A. Menth, J. Non-Cryst. Solids 1972, 8, 569.

[265] N. Takahashi, Y. Nakatani, T. Yatomi, and T. Nakamura, Chem. Mater. 2003, 15, 1763.

[266] C. De las Heras, I. Ferrer, and C. Sanchez, J. Phys.: Condens. Matter 1994, 6, 10177.

[267] M. Limpinsel, N. Farhi, N. Berry, J. Lindemuth, C. L. Perkins, Q. Lin, and M. Law, Energy Environ. Sci. 2014, 7, 1974.

[268] I. J. Ferrer and C. Sánchez, J. Appl. Phys. 1991, 70, 2641.

[269] J. D. Klein, A. Yen, and S. F. Cogan, J. Appl. Phys. 1990, 68, 1825.

[270] C. De las Heras and G. Lifante, J. Appl. Phys. 1997, 82, 5132. 


\section{WILEY-VCH}

[271] S. Mrowec and K. Hashimoto, J. Mater. Sci. 1995, 30, 4801.

[272] A. Gomes, J. Ares, I. Ferrer, M. da Silva Pereira, and C. Sanchez, Mater. Res. Bull. 2003, 38, 1123.

[273] G. Baccarani, B. Ricco, and G. Spadini, J. Appl. Phys. 2008, 49, 5565.

[274] B. Ouertani, J. Ouerfelli, M. Saadoun, B. Bessais, H. Ezzaouia, and J. Bernede, Mater. Charact. 2005, 54, 431.

[275] N. Mott, Philos. Mag. 1969, 19, 835.

[276] A. Efros and B. Shklovskii, J. Phys. C: Solid State Phys. 1975, 8, L49.

[277] N. Hamdadou, A. Khelil, and J. Bernede, Mater. Chem. Phys. 2003, 78, 591.

[278] J. R. Ares, A. Pascual, I. J. Ferrer, and C. R. Sánchez, Thin Solid Films 2004, 451-452, 233.

[279] M. Morsli, A. Bonnet, L. Cattin, A. Conan, and S. Fiechter, J. Phys. I 1995, 5, 699.

[280] M. Cabán-Acevedo, N. S. Kaiser, C. R. English, D. Liang, B. J. Thompson, H.-E. Chen, K. J. Czech, J. C. Wright, R. J. Hamers, and S. Jin, J. Am. Chem. Soc. 2014, 136, 17163.

[281] J. Werner, Solid State Phenom. 1994, 37-38, 213.

[282] J. Clamagirand, J. Ares, E. Flores, P. Diaz-Chao, F. Leardini, I. Ferrer, and C. Sánchez, Thin Solid Films 2016, 600, 19.

[283] J. Kim, G. Y. Kim, H. Moon, S. Yoon, I. W. Seo, Y. Lee, D. G. Moon, S. Ahn, and W. Jo, $R S C A d v$. 2016, 6, 81394.

[284] L. Wu, N. Y. Dzade, L. Gao, D. O. Scanlon, Z. Öztürk, N. Hollingsworth, B. M. Weckhuysen, E. J. Hensen, N. H. De Leeuw, and J. P. Hofmann, Adv. Mater. 2016, 28, 9602.

[285] V. Mlinar, Nanotechnology 2013, 24, 042001. 


\section{WILEY-VCH}

[286] C. J. Stolle, T. B. Harvey, and B. A. Korgel, Curr. Opin. Chem. Eng. 2013, 2, 160.

[287] P. V. Kamat, J. Phys. Chem. C 2008, 112, 18737.

[288] G. Chatzitheodorou, S. Fiechter, R. Könenkamp, M. Kunst, W. Jaegermann, and H. Tributsch, Mater. Res. Bull. 1986, 21, 1481.

[289] A. Ennaoui and H. Tributsch, Sol. Energy Mater. 1986, 14, 461.

[290] Q. Tong, E. R. Young, and E. Johansson, J. Phys. Chem. C 2013, 117, 25982.

[291] R. Buonsanti and D. J. Milliron, Chem. Mater. 2013, 25, 1305.

[292] M.-R. Gao, Y.-F. Xu, J. Jiang, and S.-H. Yu, Chem. Soc. Rev. 2013, 42, 2986.

[293] M. Deng, S. Shen, Y. Zhang, H. Xu, and Q. Wang, New J. Chem. 2014, 38, 77.

[294] R. Sun and G. Ceder, Phys. Rev. B 2011, 84, 245211.

[295] Q. Yu, S. Cai, Z. Jin, and Z. Yan, Mater. Res. Bull. 2013, 48, 3601-3606.

[296] P. Díaz-Chao, J. Ares, I. Ferrer, and C. Sánchez, J. Mater. Sci. 2013, 48, 4914.

[297] F. Long, J. He, M. Zhang, X. Wu, S. Mo, Z. Zou, and Y. Zhou, J. Mater. Sci. 2015, 50, 1848.

[298] T. Kinner, K. P. Bhandari, E. Bastola, B. M. Monahan, N. O. Haugen, P. J. Roland, T. P. Bigioni, and R. J. Ellingson, J. Phys. Chem. C 2016, 120, 5706.

[299] X. Liu, H.-s. Kim, J.-h. Hong, Z. Xu, H. Xiao, I.-s. Ahn, and K.-w. Kim, Powder Technology 2014, 256, 545.

[300] W. Ding, X. Wang, H. Peng, Z. Peng, and B. Dong, Mater. Res. Bull. 2013, 48, 4704.

[301] T. R. Rana, D. B. Khadka, and J. Kim, Mater. Sci. Semicond. Process. 2015, 40, 325.

[302] K. Büker, S. Fiechter, V. Eyert, and H. Tributsch, J. Electrochem. Soc. 1999, 146, 261.

[303] I. J. Ferrer, J. Ares, and C. Sánchez, Solid State Phenom. 2001, 80, 281.

[304] A. Diener, T. Neumann, U. Kramar, and D. Schild, J. Contam. Hydrol. 2012, 133, 30. 


\section{WILEY-VCH}

[305] J. Xia, X. Lu, W. Gao, J. Jiao, H. Feng, and L. Chen, Electrochim. Acta 2011, 56, 6932.

[306] S. Lehner, K. Savage, and J. Ayers, J. Cryst. Growth 2006, 286, 306.

[307] R. Schieck, A. Hartmann, S. Fiechter, R. Könenkamp, and H. Wetzel, J. Mater. Res. $1990,5,1567$.

[308] Y. Tomm, R. Schieck, K. Ellmer, and S. Fiechter, J. Cryst. Growth 1995, 146, 271.

[309] B. Ouertani, H. Ezzaouia, and B. Theys, Colloids Surf., A 2017, 525, 13.

[310] C. De las Heras and L. Bausá, J. Phys.: Condens. Matter 1997, 9, 9483.

[311] D. Liang, M. Cabán-Acevedo, N. S. Kaiser, and S. Jin, Nano Lett. 2014, 14, 6754.

[312] S. Khalid, M. A. Malik, D. Lewis, P. Kevin, E. Ahmed, Y. Khan, and P. O’Brien, J. Mater. Chem. C 2015, 39, 1013.

[313] A. Kirkeminde, M. Gong, and S. Ren, The Renaissance of Iron Pyrite Photovoltaics: Progress, Challenges, and Perspectives, in Low-cost Nanomaterials, Lin Z. and Wang J., Editors. 2014, Springer London. p. 137-166.

[314] I. Ferrer, J. Ares, and C. Sanchez, Sol. Energy Mater. Sol. Cells 2003, 76, 183.

[315] M. Limpinsel, (2015). Iron Pyrite Absorbers for Solar Photovoltaic Energy Conversion. Doctoral dissertation, UC Irvine.

[316] J. Gong, J. Liang, and K. Sumathy, Renewable Sustainable Energy Rev. 2012, 16, 5848.

[317] S. Thomas, T. Deepak, G. Anjusree, T. Arun, S. V. Nair, and A. S. Nair, J. Mater. Chem. A 2014, 2, 4474.

[318] Y. C. Wang, D. Y. Wang, Y. T. Jiang, H. A. Chen, C. C. Chen, K. C. Ho, H. L. Chou, and C. W. Chen, Angew. Chem., Int. Ed. 2013, 52, 6694.

[319] T. Ameri, N. Li, and C. J. Brabec, Energy Environ. Sci. 2013, 6, 2390. 


\section{WILEY-VCH}

[320] S. K. Balasingam, M. Lee, M. G. Kang, and Y. Jun, Chem. Commun. 2013, 49, 1471.

[321] S. Lade, M. Uplane, and C. Lokhande, Mater. Chem. Phys. 2001, 68, 36.

[322] M. Rincón, A. Jiménez, A. Orihuela, and G. Martınez, Sol. Energy Mater. Sol. Cells 2001, 70, 163.

[323] Q.-H. Huang, T. Ling, S.-Z. Qiao, and X.-W. Du, J. Mater. Chem. A 2013, 1, 11828.

[324] S. Shukla, N. H. Loc, P. P. Boix, T. M. Koh, R. R. Prabhakar, H. K. Mulmudi, J. Zhang, S. Chen, C. F. Ng, C. H. A. Huan, N. Mathews, T. Sritharan, and Q. Xiong, ACS Nano 2014, 8, 10597.

[325] M. Batmunkh, A. Shrestha, G. Gao, L. Yu, J. Zhao, M. J. Biggs, C. J. Shearer, and J. G. Shapter, Solar RRL 2017, 1, 1700011.

[326] B. Kilic, S. Turkdogan, A. Astam, S. S. Baran, M. Asgin, H. Cebeci, and D. Urk, J. Photonics Energy 2017, 45502, 1.

[327] S. Rühle, M. Shalom, and A. Zaban, ChemPhysChem 2010, 11, 2290.

[328] M. Wright and A. Uddin, Sol. Energy Mater. Sol. Cells 2012, 107, 87.

[329] H. Choi, C. Nahm, J. Kim, C. Kim, S. Kang, T. Hwang, and B. Park, Curr. Appl. Phys. 2013, 13, S2.

[330] I. Bedja, Mater. Sci.-Pol. 2011, 29, 171.

[331] X. M. Song, J. M. Wu, L. Meng, and M. Yan, J. Am. Ceram. Soc. 2010, 93, 2068.

[332] I. Bedja and A. Hagfeldt, Adv. OptoElectron. 2011, 2011.

[333] A. Kirkeminde, R. Scott, and S. Ren, Nanoscale 2012, 4, 7649.

[334] T. Xu and Q. Qiao, Energy Environ. Sci. 2011, 4, 2700.

[335] F. Goubard and G. Wantz, Polym. Int. 2014, 63, 1362.

[336] G. Li, R. Zhu, and Y. Yang, Nat. Photonics 2012, 6, 153.

[337] W. Cai, X. Gong, and Y. Cao, Sol. Energy Mater. Sol. Cells 2010, 94, 114. 


\section{WILEY-VCH}

[338] F. Zhang, X. Xu, W. Tang, J. Zhang, Z. Zhuo, J. Wang, J. Wang, Z. Xu, and Y. Wang, Sol. Energy Mater. Sol. Cells 2011, 95, 1785.

[339] B. J. Richardson, L. Zhu, and Q. Yu, Sol. Energy Mater. Sol. Cells 2013, 116, 252.

[340] E. Bastola, K. P. Bhandari, and R. J. Ellingson, J. Mater. Chem. C 2017, 5, 4996.

[341] K. P. Bhandari, X. Tan, P. Zereshki, F. K. Alfadhili, A. B. Phillips, P. Koirala, M. J. Heben, R. W. Collins, and R. J. Ellingson, Sol. Energy Mater. Sol. Cells 2017, 163, 277.

[342] P. Yu, S. Qu, C. Jia, K. Liu, and F. Tan, Mater. Lett. 2015, 157, 235.

[343] R. Murphy and D. R. Strongin, Surf. Sci. Rep. 2009, 64, 1.

[344] F. Herbert, A. Krishnamoorthy, K. Van Vliet, and B. Yildiz, Surf. Sci. 2013, 618, 53.

[345] D. Y. Wang, Y. T. Jiang, C. C. Lin, S. S. Li, Y. T. Wang, C. C. Chen, and C. W. Chen, Adv. Mater. 2012, 24, 3415.

[346] S. Shukla, G. Xing, H. Ge, R. R. Prabhakar, S. Mathew, Z. Su, V. Nalla, T. Venkatesan, N. Mathews, and T. Sritharan, ACS Nano 2016, 10, 4431.

[347] P. Prabukanthan, S. Thamaraiselvi, and G. Harichandran, J. Electrochem. Soc. 2017, 164, D581.

[348] S. Uchiyama, Y. Ishikawa, and Y. Uraoka, Japanese J. Appl. Phys. 2018, 57, 032301.

[349] E. R. Young, 2018, Crystal Growth and Surface Modification of Pyrite for Use as a Photovoltaic Material. Thesis (Ph. D.) ( DOI: 10.15760/etd.6117)

[350] X. Zhang, M. Li, J. Walter, L. O’Brien, M. A. Manno, B. Voigt, F. Mork, S. V. Baryshev, J. Kakalios, and E. S. Aydil, Phys. Rev. Mater. 2017, 1, 015402.

[351] C. Lin, D. Wang, Y. Wang, C. Chen, Y. Yang, and Y. Chen, Sol. Energy Mater. Sol. Cells 2011, 95, 1107. 


\section{WILEY-VCH}

[352] M. Gong, A. Kirkeminde, Y. Xie, R. Lu, J. Liu, J. Z. Wu, and S. Ren, Adv. Opt. Mater. 2013, $1,78$.

[353] S. Middya, A. Layek, A. Dey, and P. P. Ray, J. Mater. Sci. \& Technology 2014, 30, 770.

[354] B. Kilic, S. Turkdogan, A. Astam, O. C. Ozer, M. Asgin, H. Cebeci, D. Urk, and S. P. Mucur, Sci. Rep. 2016, 6, 27052. 


\section{WILEY-VCH}

\section{Graphical Table of Contents}

\section{Nanocrystalline Pyrite for Photovoltaic Applications}

Sadia Khalid, Ejaz Ahmed, Yaqoob Khan, Khalid Nadeem Riaz, and Mohammad Azad Malik*

Iron pyrite is a sustainable semiconductor with earth-abundant constituent elements. It has the potential to be a low cost photovoltaic material with comparatively low toxicity. The research is continuing to improve its low power conversion efficiency by synthetic routes to produce defect free high quality pyrite. This review provides a comprehensive coverage of pyrite including the synthetic routes for its preparation and the issues related to its applications particularly photovoltaic and the possible remedies to address those issues.

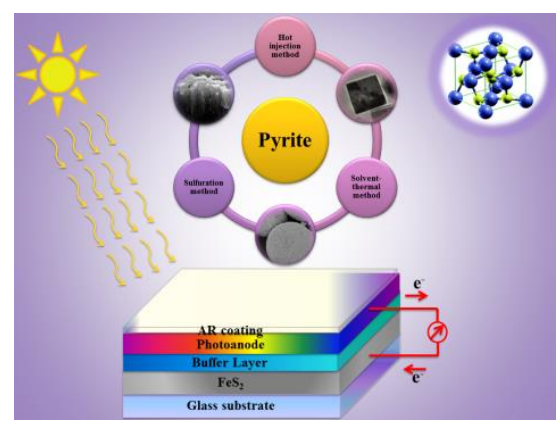

